Portland State University

PDXScholar

Winter 4-10-2018

\title{
Quantifying Knickpoint Behavior and Erosion Mechanisms in an Urbanized Watershed, Bull Mountain, Washington County, Oregon
}

Max Gregory Bordal

Portland State University

Follow this and additional works at: https://pdxscholar.library.pdx.edu/open_access_etds

Part of the Geology Commons, and the Geomorphology Commons Let us know how access to this document benefits you.

Recommended Citation

Bordal, Max Gregory, "Quantifying Knickpoint Behavior and Erosion Mechanisms in an Urbanized Watershed, Bull Mountain, Washington County, Oregon" (2018). Dissertations and Theses. Paper 4340. https://doi.org/10.15760/etd.6233

This Thesis is brought to you for free and open access. It has been accepted for inclusion in Dissertations and Theses by an authorized administrator of PDXScholar. Please contact us if we can make this document more accessible: pdxscholar@pdx.edu. 


\title{
Quantifying Knickpoint Behavior and Erosion Mechanisms
}

in an Urbanized Watershed, Bull Mountain, Washington County, Oregon

\author{
by \\ Max Gregory Bordal
}

A thesis submitted in partial fulfillment of the requirements for the degree of

\section{Master of Science}

in Geology

Thesis Committee:

Adam M. Booth, Chair

Scott F. Burns

Matthew J. Brunengo

Portland State University

2018 
(C) 2018 Max Gregory Bordal 


\begin{abstract}
Quantifying spatial and temporal patterns of rapid channelized erosion, on human time scales, is critical to understanding its processes and their consequences. This investigation utilized field observations, repeat terrestrial laser scanning (TLS), and Structure-from-Motion photogrammetry (SfM) to document the size and retreat rates of a knickpoint, defined as a localized near-vertical reach of a fluvial channel, and its contribution to erosion, in an urbanizing landscape with a loess substrate. The Bull Mountain area, in Washington County, southwest of Portland, Oregon, is an ideal study area, offering a measurable knickpoint that translates the response of the rapid erosion throughout this transient system. Previous urbanization there has increased peak flows in streams, potentially initiating rapid channel incision and associated slope instability and sediment pollution, affecting real property and infrastructure. Despite the documented increase in discharge, upstream migration rates of the knickpoint, as well as the overall channel erosion rate, were unknown.
\end{abstract}

Sequential point cloud analysis quantified topographic changes in the landscape, in three dimensions, throughout time. The measured minimum knickpoint migration rates ranged from $-0.23 \mathrm{~m} / \mathrm{yr}$ to $-2.45 \mathrm{~m} / \mathrm{yr}$ with an average of $-1.52 \mathrm{~m} / \mathrm{yr}$ and minimum of total volume eroded of $6.49 \mathrm{~m}^{3}$. The negative sign indicates the upstream direction. An extreme erosion event caused $-12.5 \mathrm{~m}$ of erosion in $\sim 4.5$ months. The interval including the extreme erosion event was recorded separately using traditional measurement techniques and resulted in an average retreat rate of $-4.31 \mathrm{~m} / \mathrm{yr}$. Analysis of patterns of erosion revealed four primary modes: exfoliation, large soil block failure, undercutting at 
the knickpoint base, and upper bank failure. Results from soil analyses indicate a layer of high bulk density $\left(1.85 \mathrm{~g} / \mathrm{cm}^{3}\right)$ loess at the base of the upper channel may restrict the channelized incision for that reach and control the height and geometry of the knickpoint face, leading to a parallel mode of retreat. From the observed erosion rates a substrate specific average value of erodibility, or K value, of $0.01 \mathrm{~m}^{0.2} \mathrm{yr}^{-1}$, was determined. As erosion forces the retreat of these knickpoints upstream, the effects of increasing urban runoff are felt throughout the watershed. The work presented here provides insight on the physical controls driving erosion and can serve as a prologue for future mitigation. 


\section{Dedication}

A poem, in Tamarian:

Darmok and Jalad at Tanagra

Darmok and Jalad on the Ocean

Shaka, when the walls fell

Shaka, when the walls fell

Kiazi's children, their faces' wet

Temarc, The river Temarc. In winter

Sokath, his eyes open

(Kolbe, 1991) 


\section{Acknowledgments}

Thanks Hillarie, 1-4-3

Thank you to my advisor Adam Booth and committee members Scott Burns and Matthew Brunengo for their incredible support and feedback.

Thank you to the Tualatin Riverkeepers and concerned community members Paul

Whitney, Rowland French, and Mike Meyers for guidance and access during this project.

Thank you to the Oregon Chapter of AEG for funding to present a portion of this research at the 2016 AEG Annual Meeting in Kona, Hawaii.

Thanks to Jon Barnes for assistance in the field.

Thanks to PSU Geology department. 


\section{Table of Contents}

Abstract $\quad$ i

Dedication $\quad$ iii

Acknowledgements

List of Tables $\quad$ vi

List of Figures $\quad$ vii

1. Introduction 1

2. Channel Profile Analysis 11

3. Quantifying Knickpoint Erosion 27

4. Soil Analysis $\quad 82$

5. Establishing Erodibility (K) for Loess 95

$\begin{array}{ll}\text { 6. Discussion } & 105\end{array}$

7. Conclusions 112

$\begin{array}{ll}\text { References } & 116\end{array}$

Appendix A: Additional Point Cloud Analysis Methodology 123

Appendix B: Additional Point Cloud Differencing Analysis and Figures 135 


\section{List of Tables}

$\begin{array}{lr}\text { 2.1 Metrics for channels with large knickpoints } & 18\end{array}$

3.1 Details of erosion and precipitation measurements 48

3.2 Analysis of fit and confidence of linear regression for four precipitation metrics

3.3 Point cloud error propagation

4.1 Field and laboratory characteristic of soil samples

5.1 Stream power calculated erodibility value comparison

102 


\section{List of Figures}

1.1 Map of the northwest United States of America 3

1.2 Map of study area: Bull Mountain, Washington County, Oregon 5

2.1 Slope map of Morningstar Creek highlighting automatic vs manual stream path extraction $\quad 14$

2.2 Elevation profiles for eight main streams on Bull Mountain 17

2.3 Elevation profiles for Morningstar Creek and Meyers Creek 18

2.4a Slope map of Morningstar Creek 20

2.4b Drainage area map of Morningstar Creek 21

2.5a Slope map of Meyers Creek 22

2.5b Drainage area map of Meyers Creek 23

3.1 Common features of a knickpoint 29

3.2 Four modes of knickpoint retreat $\quad 30$

3.3 Headwaters of Morningstar Creek 33

3.4 Morningstar Creek knickpoint, upstream view (3/20/2015) 34

3.5 Morningstar Creek knickpoint, downstream view (3/20/2015) 35

3.6 Smaller knickpoints on Bull Mountain 36

3.7 Basalt and loess exposed on Bull Mountain 37

3.8 Manual retreat measurement (4/9/2017) 39

3.9 Manual retreat measurement reference points (4/9/2017) 40

3.10 Mechanism of erosion: block failure 43

3.11 Mechanism of erosion: exfoliation and upper bank failure 44

3.12 Mechanism of erosion: undercutting 45 
3.13 Point cloud differencing for interval 8/19/2015 - 10/23/2015

3.14 Point cloud differencing for interval 10/23/2015 - 4/29/2016

3.14c Rootball near Morningstar Creek knickpoint, pre collapse $(10 / 23 / 2015)$

3.14d Undercutting of rootball near

Morningstar Creek knickpoint (11/11/2015)

3.14e Rootball near Morningstar Creek knickpoint, post collapse (1/20/2016)

3.15 Point cloud differencing for interval 4/29/2016 - 9/5/2016

3.16 Point cloud differencing for interval 9/5/2016 - 11/18/2016

3.17 Lower channel of Morningstar Creek, upstream view (4/9/2017)

3.18 Panoramic image showing extreme erosion of Morningstar Creek knickpoint (4/9/2017)

3.19a Sheet failure margin (4/9/2017)

3.19b Large block failure (4/9/2017)

3.20 Plots of retreat rate vs total precipitation

3.21 Plots of retreat rate vs wetting and drying cycles

3.22 Plot of exfoliation based retreat rate vs wetting and drying cycles

3.23 Plots of retreat rate vs average precipitation rate

3.24 Plots of retreat rate vs percentage of days with over $0.015 \mathrm{~m}$ of precipitation 
4.3 Plot of Torvane derived shear strength vs bulk density

4.4 Grain size gradation curve 


\section{Introduction}

\subsection{Motivation}

The erosion rate of channelized portions of a landscape is primarily dependent on the power or shear stress of the flowing water and the local integrity of geologic material and structures present (Gilbert, 1907; Selby, 2005). In landscapes where the main process for erosion is channelized flow, changes in morphology can be interpreted as responses to changes in water and sediment supply (Lane, 1953; Booth and Henshaw, 2001). In urbanized watersheds, an increase in runoff from impervious surfaces can degrade local streams by intensifying erosion leading to unstable channel conditions (Waite et al., 2008). A channel is considered unstable when deposition and/or scour is occurring on the banks or bed (Lane, 1953). The work presented here quantifies the amount of erosion and mechanisms causing erosion due to overland flow of water into small channels in an urbanized study area. This formerly natural system is under transient conditions. Rapid incision through loess focused at a retreating vertical step in the channel has resulted in drastic geomorphic changes.

G. K. Gilbert's study of the Henry Mountains first established and defined the processes (weathering, transportation, and corrasion) that contribute to the erosion of landscapes (Gilbert, 1877). Later, Gilbert's work in The Convexity of Hilltops was an early discussion of the relationship between the form of a hill and the incision and transport of material in the stream beds on their slopes (Gilbert, 1909). The study of landscape evolution, defined as change in relief and landscape form due to uplift and subaerial erosion over time, has shifted from qualitative interpretation to quantitative 
analysis over the last half century (King, 1953). Applying the general laws of physics established a mathematical basis to describe the change in landform over varying time scales (Leopold and Langbein, 1962). Geomorphologists for the past 150 years have been trying to constrain the parameters influencing these physical controls. One modern approach is to focus on the incision of streams as a primary driver of change and use the stream power equation to model a landscape, defining erosion as a power-law function of channel slope and drainage area (Howard and Kerby, 1983; Howard, 1994):

$$
\mathrm{E}=\mathrm{K} A^{m} S^{n}
$$

where $\mathrm{E}$ (in units of length/time, $\mathrm{L} / \mathrm{T}$ ) is erosion rate, $\mathrm{K}\left(\mathrm{L}^{1-2 \mathrm{~m}} \mathrm{~T}^{-1}\right)$ is the erodibility of the substrate, $A\left(\mathrm{~L}^{2}\right)$ is drainage area, $\mathrm{S}(\mathrm{L} / \mathrm{L})$ is the slope of the channel, and $\mathrm{m}$ and $\mathrm{n}$ are coefficients controlling the influence of $\mathrm{A}$ and $\mathrm{S}$. There is a recognition that even in landscape evolution studies based on transport laws such as Eq. (1.1), a lack of corroboration between model results and real landscapes exists (Seidl and Dietrich, 1992). An example of this disconnection is the use of the coefficient, $K$, in the stream power equation, a parameter for bedrock erodibility, that is often unknown and poorly estimated (Whipple and Tucker, 1999). One approach toward more physically based models is to quantify unknown parameters with field studies focusing on mechanics of erosion and factors controlling incision (Sklar and Dietrich, 1998). This was the approach taken in this thesis research.

Over 36 months I studied a rapidly retreating knickpoint in a small channel on the northern flanks of Bull Mountain, southwest of Portland, Oregon (Fig. 1.1). A knickpoint is the ungraded convex break in a channel's longitudinal profile, separating upper and 
lower graded sections (Brush and Wolman, 1960; Gardner, 1983). Examples of knickpoints in the field vary from small rapids to high waterfalls and are commonly the

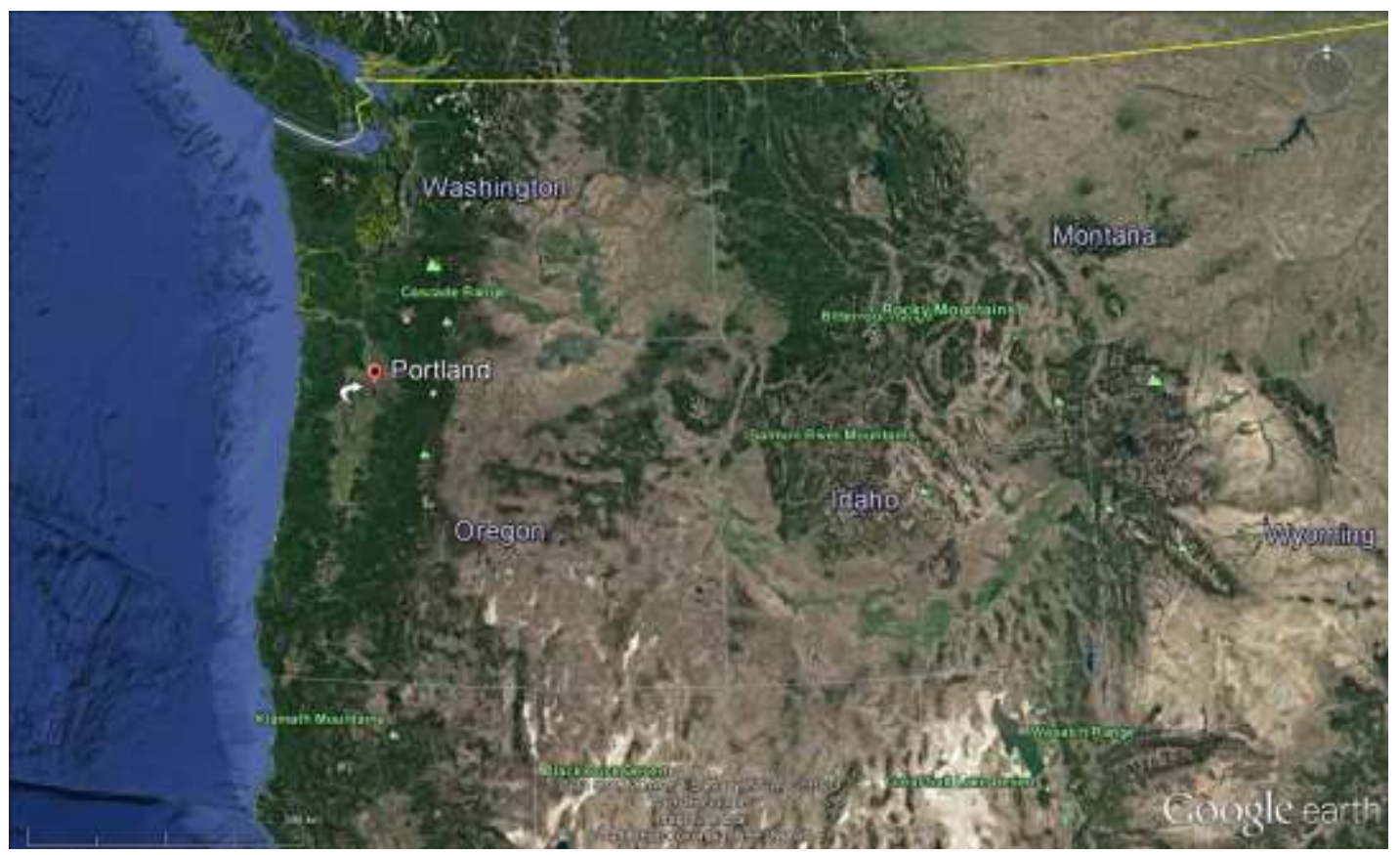

Figure 1.1: Map of the northwest United States of America. A red flag shows the location of Portland, Oregon and white arrow shows the approximate location of the study site.

most dramatic features of a drainage network. If knickpoints are present in a basin, their propagation up a channel system can provide real-time evidence for a landscape's response to perturbation, under a state of disequilibrium (Crosby and Whipple, 2006). At a knickpoint the slope of the channel is steeper than the average, and this slope increase can cause an increase in sediment transport relative to the upstream and downstream reaches. If this relationship is sustained, the knickpoint will migrate upstream, opposite the direction of water flow (Brush and Wolman, 1960). The case study reported here provides new insight on a knickpoint's rate and mechanisms of upstream retreat, along 
with a better understanding of the mechanics behind erosion under human influence. The regional situation provided an opportunity to measure rates of change and physical parameters, in particular the erodibility constant $\mathrm{K}$, which was then compared to other studies with similar conditions.

Two large knickpoint sites on Bull Mountain (Fig. 1.2) are located in areas where anthropomorphic landforms, surfaces, and infrastructure have preferentially directed surface runoff. The resulting erosion, focused at a knickpoint, has consequences on both private and public land where it affects slope stability, property value, and downstream sedimentation. My research questions were: (1) What are the patterns of erosion and retreat rates of those knickpoints?, (2) What controls knickpoint height and the depth of channelized incision into loess?, and (3) What is the site specific bedrock erodibility constant for loess in the stream power law? Exploring the following research questions will aid in future planning, benefiting both scientific understanding and the local community. 

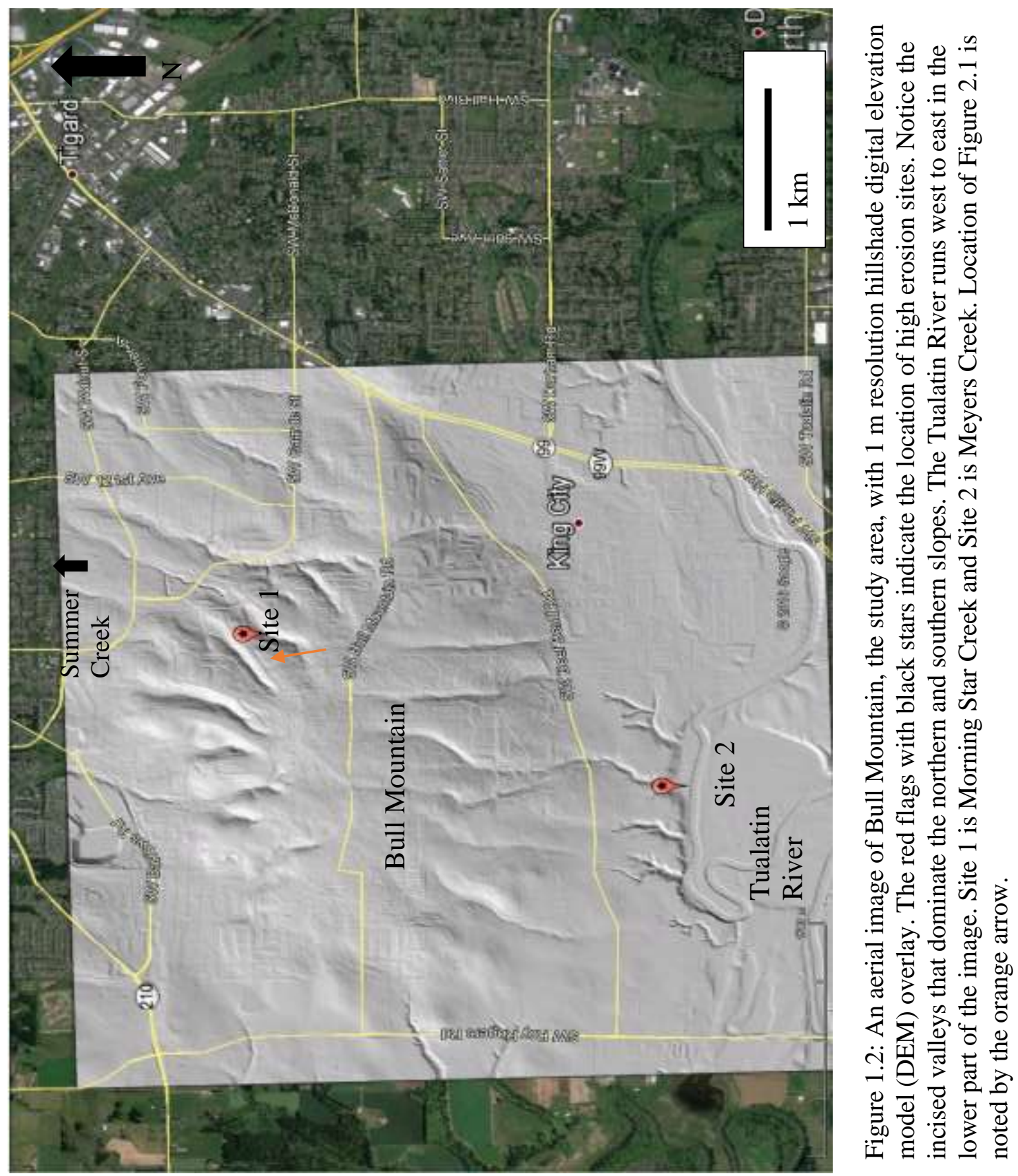

\subsection{Study Area: Bull Mountain, Oregon}

Bull Mountain is within the Tualatin River basin (TRB), a roughly $1,800 \mathrm{~km}^{2}$ sub-basin located within the northwestern portion of the Willamette Valley, between the Cascade and Coast ranges of Oregon (Popowski, 1996; Praskievicz and Chang, 2011). The rapidly 
eroding sites of interest are located on Bull Mountain (Fig. 1.2), one of a series of topographic highs near the Tualatin River and the southern boundary of the TRB (Popowski, 1996). The Tualatin River runs across the basin for $134 \mathrm{~km}$ until it meets the Willamette River, the region's main drainage route (Praskievicz and Chang, 2011). The slopes and valleys of Bull Mountain contain many small (meters in width) streams and gullies. Like the larger Willamette Valley, the Tualatin Valley was formed by the downwarping of basalt groups into a structural basin (Laenen, 1983; Evarts et al., 2009) Bull Mountain acts as an intra-basin drainage divide, diverting some water to Fanno Creek (a tributary of the Tualatin River) on the north side, while surface water flowing down the southern flanks feeds directly into the Tualatin River (Popowski, 1996). The finger-like ridges, extending out from the center of the mountain (these are highlighted by the hillshade overlay in Fig. 1.2) are the location of housing developments and neighborhoods that transformed this area from rural farmland to suburban neighborhoods from the 1960s to present (Shively, 1993). These ridges act as mini drainage divides separating first-order valleys into individual catchments. The erosion sites that were studied lie in these valleys, the mountaintop's main avenues for sediment and water transport.

The main geologic units in the Bull Mountain area are Columbia River Basalts, Missoula Flood deposits, and loess. In the Miocene, 16.5 - 14.5 Ma, the Grande Ronde (early) and Wanapum (middle) members of Columbia River Basalt Group (CRBG) covered the region. These flows overlay a poorly understood basement complex of sedimentary and volcanic units, likely of the Siletz Terrane, Waverly Heights basalts, and 
Tillamook Volcanics (Duncan, 1982; McPhee et al., 2014). The geographic extent of the earlier flows of the CRBG from the east were by limited the north-south trending Portland Hills Anticline, formed in the late Cenozoic (Blakely et al., 2004). This ancestor to the Portland Hills composes the eastern edge of the TRB (Evarts et al., 2009). A now isolated deposit of CRBG forms the underlying shape and relief of Bull Mountain (Hart and Newcomb, 1965). The Portland Hills, also known as the Tualatin Mountains, were uplifted due to folding in the late Neogene (McPhee et al., 2014). The Portland Hills are offset by the northwest trending Portland Hills fault (Blakely et al., 1995). Paleomagnetic evidence indicates a clockwise rotation of the Pacific Northwest during the Cenozoic, and studies suggest that regional lithospheric deformation occurred as a response (Wells, 1990; England and Wells, 1991).

At 18,000 - 15,000 calendar years B.P., repeated cataclysmic breaches of ice dams holding back Glacial Lake Missoula led to the Missoula Floods, which deposited silt, sand and gravel in the TRB (Allen et al., 2009). These deposits lapped onto the base of the existing basalt dome, around the base of the ancestral Bull Mountain, entering the TRB via a flood channel through Oswego Lake. Sand and silt are mapped (beyond the reach of the gravels) up the Tualatin Valley (Bretz, 1969). This left the raw material for eolian silt, or loess, to blanket Bull Mountain (McPhee et al., 2014). The loess conformed to the existing paleotopography, capping ridges and spurs (Trimble, 1963). Loess in the study area is typically less than 3 m thick (Lentz, 1977). The loess in the valleys, channels, and at the knickpoints is the main geologic material exposed. The loess is surveyed as Cornelius and Kinton Series silt loams (Green, 1982). While the loess layers 
are considered cohesive and laterally uniform, they are vertically heterogeneous. Dense hydro-consolidated layers called fragipans, commonly stratigraphically break up the loess unit (Smalley et al., 2015).

\subsection{Project Sections}

This investigation (and thesis) is divided into four sections to better establish the behavior and mechanisms of the knickpoint, which span multiple spatial scales. First, a channel profile analysis was completed for the Bull Mountain area watersheds, to characterize the geometric similarities and differences among first-order basins. Second, I performed repeat terrestrial laser scanning (TLS) measurements (four times) and Structure-fromMotion (SfM) photogrammetry (once) on a rapidly eroding knickpoint, creating ten timeinterval pairs of point clouds to calculate volumetric erosion rates. Third, I measured the physical properties of the substrate to determine the influence of soil characteristics on the pattern of erosion quantified with the point cloud analysis. Last, I used the erosion rates from the point cloud data to back-calculate a site specific erodibility constant (K). Below, I first summarize the motivation for each section. Then, in sections 2 - 5, I present a brief introduction, methodology, results, and a section specific discussion. In sections 6 and 7 the combined insights of these four sections are discussed and conclusions are drawn. 


\subsubsection{Channel Profile Analysis}

To establish the larger geomorphic context of the study area, a lidar-based channel profile analysis was performed on the streams originating on Bull Mountain. This compared the longitudinal profile of streams containing and not containing knickpoints. I analyzed the relationship between elevation and downstream distance to examine patterns of geomorphic process regimes and assess whether or not knickpoints could be identified from channel profile analysis alone.

\subsubsection{Quantifying Knickpoint Erosion}

Based on the channel analysis and field reconnaissance, I identified one knickpoint, in the Morningstar Creek, for focused study. Knickpoints are oversteepened reaches of a channel, and upstream migration of these headcuts often occurs at rates of meters per year (Muehlbauer and Doyle, 2012). I determined the volume of material eroded from the knickpoint over the course of one water year at that site on Bull Mountain. Point cloud analysis offered a means to accomplish this, measuring and recording the changes to the channel over time with high $(<10 \mathrm{~cm}$ ) precision (Resop and Hession, 2010). Using open source point cloud analysis software, I aligned and differenced interval pairs of TLS and SfM point clouds to produce a record of the volumetric erosion and upstream erosion rate of the knickpoint face between September 2015 and April 2017. In addition to the amount of erosion, the differencing of point clouds offered a way to visualize the spatial patterns of erosion at the knickpoint face and document erosion mechanisms. The quantification of retreat rates and patterns of erosion provide insight into the behavior of 
the substrate and physical controls on erosion and can be used with landscape evolution theory to estimate the substrate's erodibility (see section 1.3.4 below).

\subsubsection{Soil Analysis}

To address my second research question I performed soil sampling and analysis on a vertical transect of the loess substrate at the knickpoint face, following Lindbo et al. (1994) who focused on fragipan identification and bulk density analysis of loess. Density, shear strength, and grain-size distributions were measured and spatially compared to the defining features and incision depth of the knickpoint.

\subsubsection{Establishing Erodibility (K) for Loess}

The artificial rerouting of surface runoff from urbanization in a watershed can produce large changes to the load of water and sediment that affects the channel network (Booth and Henshaw, 2001). Here, I used the erosion rates determined from the point cloud measurements and the stream power law (Whipple and Tucker, 1999) to back-calculate the erodibility $(\mathrm{K})$ for loess. This establishes an erodibility constant for loess which is a key, yet typically unknown, input parameter for long-term landscape evolution models. I compared my calculated erodibility constant with values determined from landscape evolution studies, under a wide range of geologic conditions and spatial scales. 


\section{Channel Profile Analysis}

\subsection{Introduction}

The ability to characterize the geometry and topographic signature of a channel at the drainage basin scale is important for process based studies where channel comparisons are necessary (Phillips and Lutz, 2008). On Bull Mountain there are eight first order steams that flow down its flanks (Fig. 1.2). Based on field reconnaissance, only two of these are known to contain large knickpoints. Analyzing these local stream profiles can yield an interpretation of the landscape from the perspective of the erosion cycle (Hack, 1957). Determining the slope and contributing drainage surrounding a channel provides further insights into the governing geomorphic transport processes (Dietrich et al., 2003). The transport processes vary within a given drainage area and are often categorized into so-called geomorphic regimes. The areas containing low drainage area and steep slopes are typically associated with hillslope processes like landsliding. The areas containing high drainage area and gentle slopes are typically associated with alluvial process like overland flow (Montgomery and Foufoula-Georgiou, 1993; Montgomery and Dietrich, 1994). The availability of high resolution airborne lidar data sets in conjunction with field observations facilitated my quantification of stream profiles and the watersheds' drainage area and slope distributions, for the channels on Bull Mountain (McNamara et al., 2006).

Typically, in actively uplifting channels where an equilibrium between the rate of base level fall and erosion exists, a power law relationship (linear trend in log-log space) between drainage area and slope is observed (Willgoose et al., 1991). When this relationship holds true, a common shape to a stream's longitudinal profile is smoothly 
convex up (Phillips and Lutz, 2008). Here the channels with knickpoints are locally in a transient state, where erosion on a local scale is outpacing the long-term rate of base level fall. In these cases the shape of the profile and the distribution of geomorphic processes may differ from steady-state predictions. I hypothesized that there would be similarities in channel profiles and geomorphic regime features between the two streams containing large knickpoints.

\subsection{Methods}

I collected the high resolution digital elevation model (DEM) from publicly available lidar from the open source data platform, Open Topography (opentopography.com), which is a National Science Foundation supported lidar data repository. The lidar data set was collected on 3/15/2007 for the Oregon Department of Geology and Mineral Industries (DOGAMI) by Watershed Sciences. It features $1 \mathrm{~m}$ grid spacing. Since the study area is mostly covered by a suburban neighborhood, artifacts and null space were prevalent in the data set. I used the built-in preprocessing feature on Open Topography to fill gaps in the data set for analysis in ArcGIS. During lidar collection, the elevation of tops of houses and structures are recorded, but these elevations do not represent the true ground elevation at a given location. The area of the DEM product within the footprint of these structures is typically deleted and left as null space. The preprocessing feature creates elevation data for these null spaces, from the nearest neighboring cell, filling in the gaps created by houses and infrastructure, and allowing for subsequent calculations on a complete data set. 
I then performed highly supervised manual stream profile extraction. Due to the study area's urbanized nature, anthropomorphic alteration to the landscape appears as elevation changes in the DEM. Sidewalks, roadways, walking paths, cul de sacs, and driveways are some of the many features that appear as elevation or slope change. Figure 2.1 shows an example of the difference between the automated stream path extraction, and the true stream path, verified by field observations. The automated stream path extraction process that I first tested based the path of a stream on where surface water would collect and flow, using and comparing the relative elevations of each cell from the DEM. Specifically, the algorithm determined the path of steepest descent from each grid cell in the DEM, then calculated the number of upstream cells that accumulated flow to each downstream cell, and classified cells as a stream if an arbitrary accumulation threshold was exceeded. However, an erroneously high elevation in a single cell on the DEM can cause an alteration of stream routing from its true path. Therefore, instead of automatically extracting channels, I manually traced each stream originating on Bull Mountain from its outlet to its headwaters based on the hillshade DEM, creating a stream path vector in ArcGIS. The upstream distance and elevation data from my lines were exported Excel to and plotted to view the longitudinal profiles of all first-order streams on Bull Mountain. I graphed elevation vs upstream distance for all streams in a single plot to help identify trends in shape, such as consistent headwater/outlet elevations, or deviations (sharp inflection points) from the classic convex-up shape, if any. The two streams containing large knickpoints were additionally plotted together for further examination. 


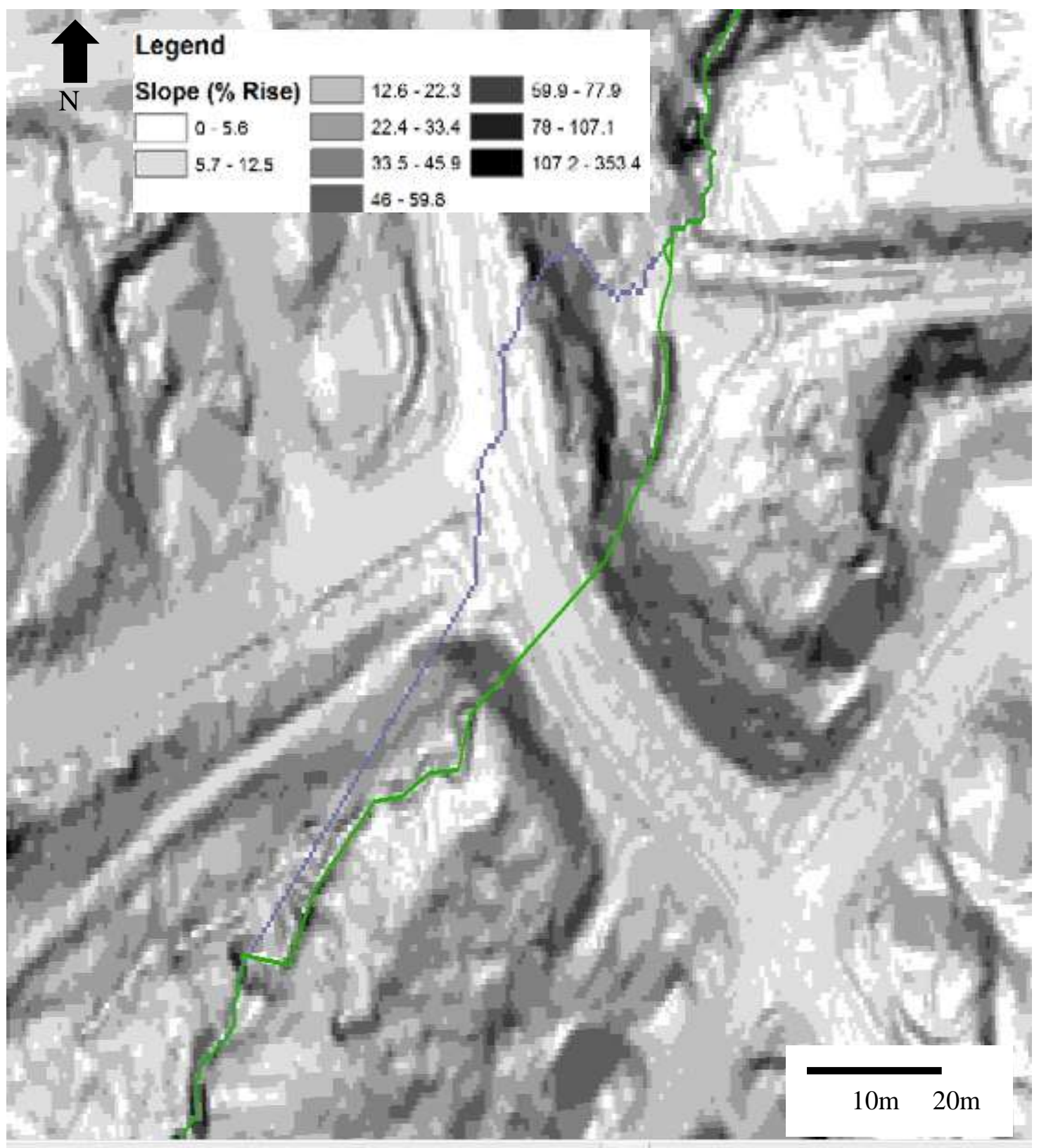

Figure 2.1: A subset of the slope map for the Morningstar Creek drainage basin that illustrates differences between the automated and manual stream path extraction. The green line shows the true stream path, manually selected, and the blue line shows the stream path as detected by the automated GIS tool, which is not accurate. An erroneously high elevation in a single cell on the DEM (where the two paths diverge) caused an alteration of stream routing from its true path. Location is indicated on Figure 1.2 with an orange arrow. 
I used this new, accurate stream path to further examine the topography around the two channels containing large knickpoints. To ensure a precise measurement of drainage area in the highly complex urbanized area, the underlying DEM was reconditioned by artificially lowering the elevation by $100 \mathrm{~m}$ at points along the manually defined stream paths to ensure that the flow accumulation algorithm in ArcGIS correctly defined drainage area at the points along the actual stream path.

After loading the reconditioned DEM in ArcGIS, I followed the sequence of steps for watershed delineation described on the GIS 4 Geomorphology website (www.gis4geomorphology.com) as follows (Cooley, 2016). First, using the 'fill' tool, I created a new DEM with any pits filled in. Next I took the filled DEM and created a layer that shows the flow direction from each pixel to its lowest neighboring pixel. The 'flow direction' layer was taken and processed into a flow accumulation layer using the 'flow accumulation' tool, assuming that surface flow would follow the path of steepest descent. The next steps focus on two drainage channels that contain large knickpoints: Morningstar Creek (Site 1) and Meyers Creek (Site 2) shown in Figure 1.2. Using the slope maps created from the original DEM, I identified the outlet point of each stream where it meets Summer Creek or the Tualatin River and placed a marker, converting it from a graphic to a geospatial feature. Next I converted the outlet point to a pixel using the 'snap pour point' tool. This 'snap pour point' pixel allows the watershed tool to be run on the 'flow direction' layer, which produces a 'watershed' layer. Finally the 'watershed' layer was converted from a raster to a polygon, letting me clip the underlying DEM, segmenting just the data points within the single watershed. Exporting the flow 
accumulation, or equivalent upstream drainage area, and slope rasters yielded a watershed scale view of the variations in slope and drainage area for the streams with the large knickpoints.

\subsection{Observations and Results}

The eight stream profiles, shown in Figure 2.2, all have shapes that are broadly concave upward. Most profiles have a 'kink' near the middle of their reach, corresponding to the base of Bull Mountain where there is a transition from hillslopes to floodplains. There are, however, several differences from this general trend. Many of the profiles exhibit apparent sharp vertical breaks in slope or spikes in elevation due to the stream path crossing under anthropomorphic features. In unaltered drainages, these patterns are typically an indication of the presence of knickpoints; however in this study area, they may indicate anthropogenic features that need to be verified on a case-by-case basis. To determine whether actual knickpoints could be distinguished from anthropomorphic features based on stream profile analysis alone, two streams featuring known large knickpoints, Morningstar Creek and Meyers Creek, are plotted separately (Fig. 2.3). The relative knickpoint locations in these reaches are different. Morningstar Creek's knickpoint is close to the headwaters ( $2000 \mathrm{~m}$ upstream from Summer Creek), while Meyers Creek knickpoint is near the outlet ( $20 \mathrm{~m}$ upstream from the confluence with the Tualatin River) (Table 2.1). The data points from the Morningstar channel are regressed with an exponential equation $y=45.53 \mathrm{e}^{0.0005 x}, \mathrm{R}^{2}=0.951$. The data points from the Meyers Creek channel are regressed with an exponential equation 
$y=34.391 \mathrm{e}^{0.0003 x}, \mathrm{R}^{2}=0.9909$. An exponential fit was chosen because it highlights the break in channel slope at the base of Bull Mountain, where a transition to flatter floodplains occurs. Although the $\mathrm{R}^{2}$ values are generally high, indicating that an exponential fit explains a large proportion of the variance, there are systematic biases such that the regression lines over-predict the elevation of both channels at mid-stream, near the base of Bull Mountain.

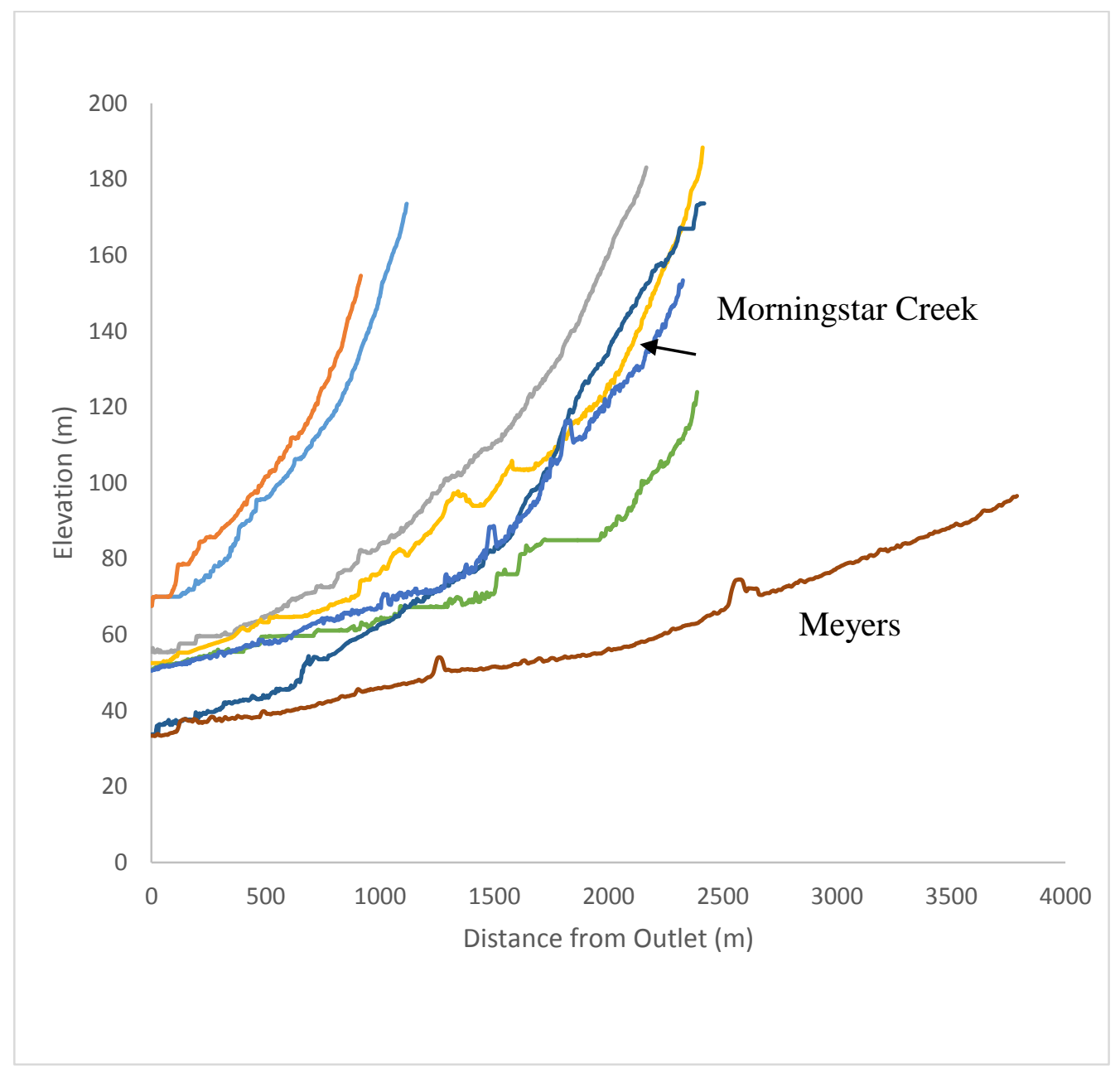

Figure 2.2: Elevation profiles for the eight main streams around Bull Mountain. The large spikes in the data correspond to anthropogenic topographic breaks, for example where a stream flows beneath a road through a culvert. Note the streams share a similar shape, roughly following an exponential curve. The arrow shows the approximate location from the previous image (Fig. 2.1) highlighting the manual stream path methodology. 


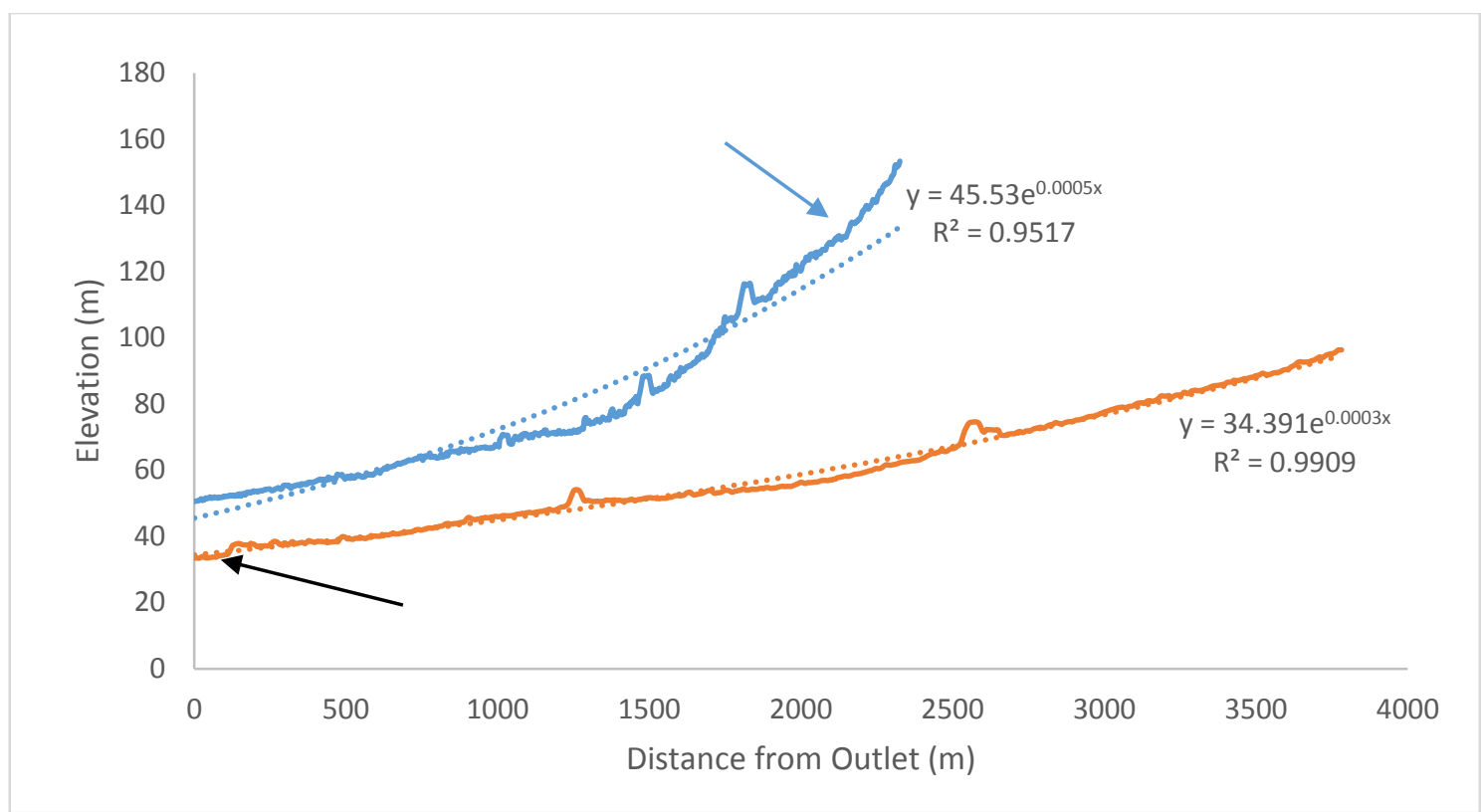

Figure 2.3: A plot of elevation profiles for Morningstar Creek (blue) and Meyers Creek (orange). The arrows indicate the approximate location of the knickpoints in each of those drainages. An exponential trend line is fitted to both reaches to highlight the break in channel slope at approximately $70 \mathrm{~m}$ elevation (Morningstar Creek) and $50 \mathrm{~m}$ elevation (Meyers Creek).

Table 2.1: Channel profile metrics for the two streams containing large knickpoints on Bull Mountain

\begin{tabular}{|c|c|c|c|c|}
\hline $\begin{array}{l}\text { Stream } \\
\text { Name }\end{array}$ & $\begin{array}{l}\text { Length of } \\
1^{\text {st }} \text { Order } \\
\text { Stream } \\
(\mathrm{m})\end{array}$ & $\begin{array}{l}\text { Relief } \\
\text { (m) }\end{array}$ & $\begin{array}{l}\text { Distance } \\
\text { of } \\
\text { Knickpoint } \\
\text { from } \\
\text { Outlet } \\
\text { (m) }\end{array}$ & $\begin{array}{c}\text { Fit } \\
\text { Coefficient } \\
\text { (b) of } \\
\text { Exponential } \\
\text { Regression } \\
\left(\mathrm{y}=\mathrm{ae}^{\mathrm{bx}}\right)\end{array}$ \\
\hline $\begin{array}{l}\text { Morningstar } \\
\text { Creek }\end{array}$ & 2325 & 102 & $\sim 2000$ & 0.0005 \\
\hline $\begin{array}{l}\text { Meyers } \\
\text { Creek }\end{array}$ & 3788 & 63 & $\sim 20$ & 0.0003 \\
\hline
\end{tabular}


The local slope maps of the areas surrounding Morningstar and Meyers Creeks (Fig. 2.4a and 2.5a) show the topography of the watersheds surrounding those first-order streams. On the north side of Bull Mountain the main channelized valley of Morningstar Creek runs from the south to the north where it meets Summer Creek. The majority of hillslopes in the study area have slopes steeper than $5 \%$. Roads and buildings are noticeable as slope changes in the topography. The slope map for Morningstar Creek (Fig. 2.4a) channel shows a drainage basin that is urbanized along its entire reach. The slope map for the Meyers Creek channel (Fig. 2.5a) shows that the upper portion of the channel is heavily urbanized while the lower half of the channel is surrounded by farm land and less infrastructure. The drainage area maps for the two knickpoint channels (Fig. $2.4 \mathrm{~b}$ and $2.5 \mathrm{~b}$ ) reveal that the Morningstar Creek basin has a total drainage area of 0.8 $\mathrm{km}^{2}$, and the Meyers Creek basin has a total drainage area of $\sim 2 \mathrm{~km}^{2}$. The hillslopes bordering the Morningstar Creek channel near the knickpoint have a $22 \%$ average slope, and the knickpoint is located in a drainage area of $225,195 \mathrm{~m}^{2}$ (Fig 2.4b). The terrain near the knickpoint in the Meyers Creek channel has an $8 \%$ average slope, and the knickpoint is located at a drainage area of 1,355,552 $\mathrm{m}^{2}$ (Fig 2.5b). Based on this analysis of two cases, it appears that a threshold drainage area, or a specific range of slopes, does not control the location of knickpoints in the study area. 


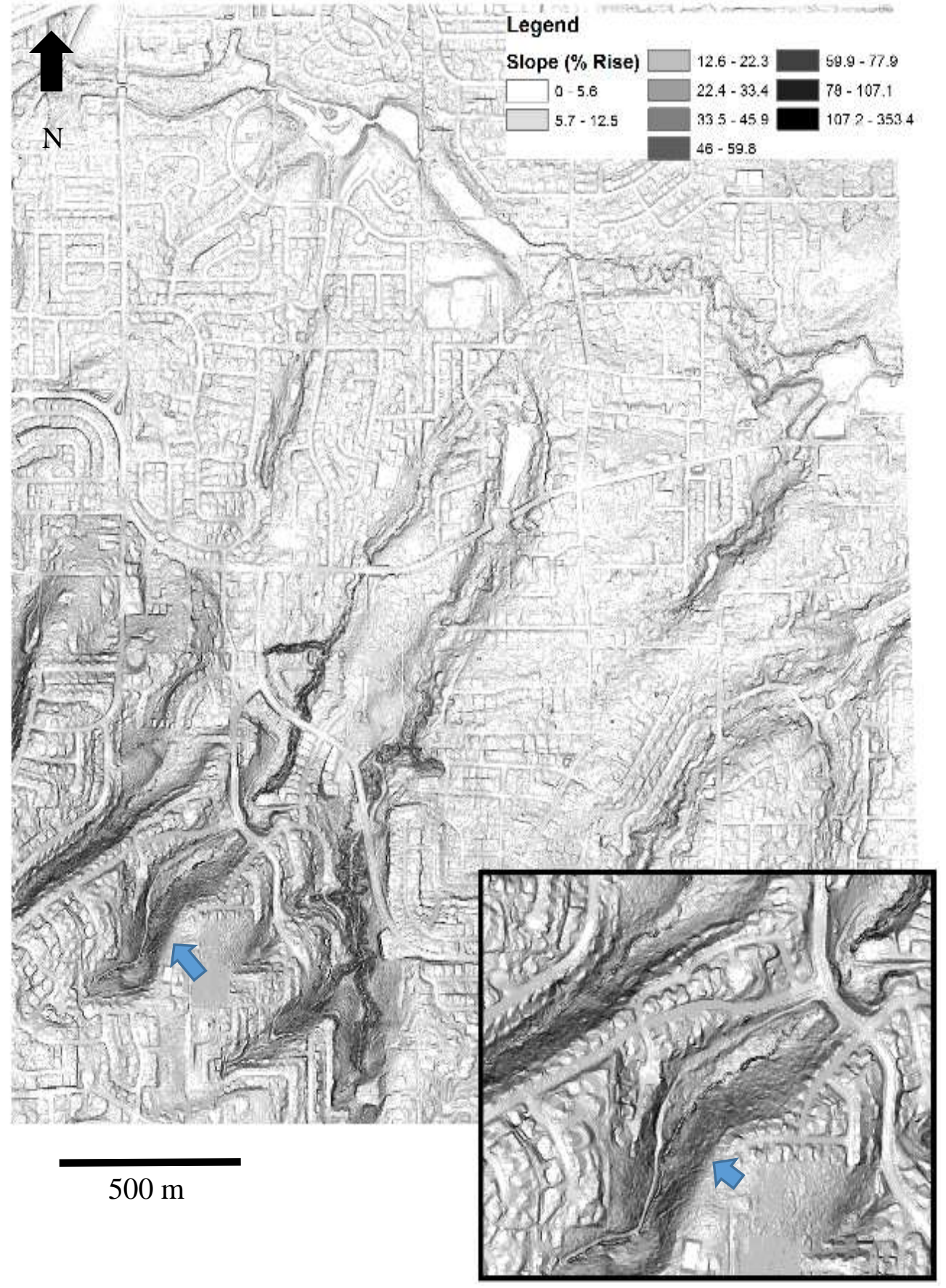

Figure 2.4a: Slope map showing percent rise around Morningstar Creek, Site 1. The blue arrows indicates the same location, the erosional knickpoint on both the map and inset. 


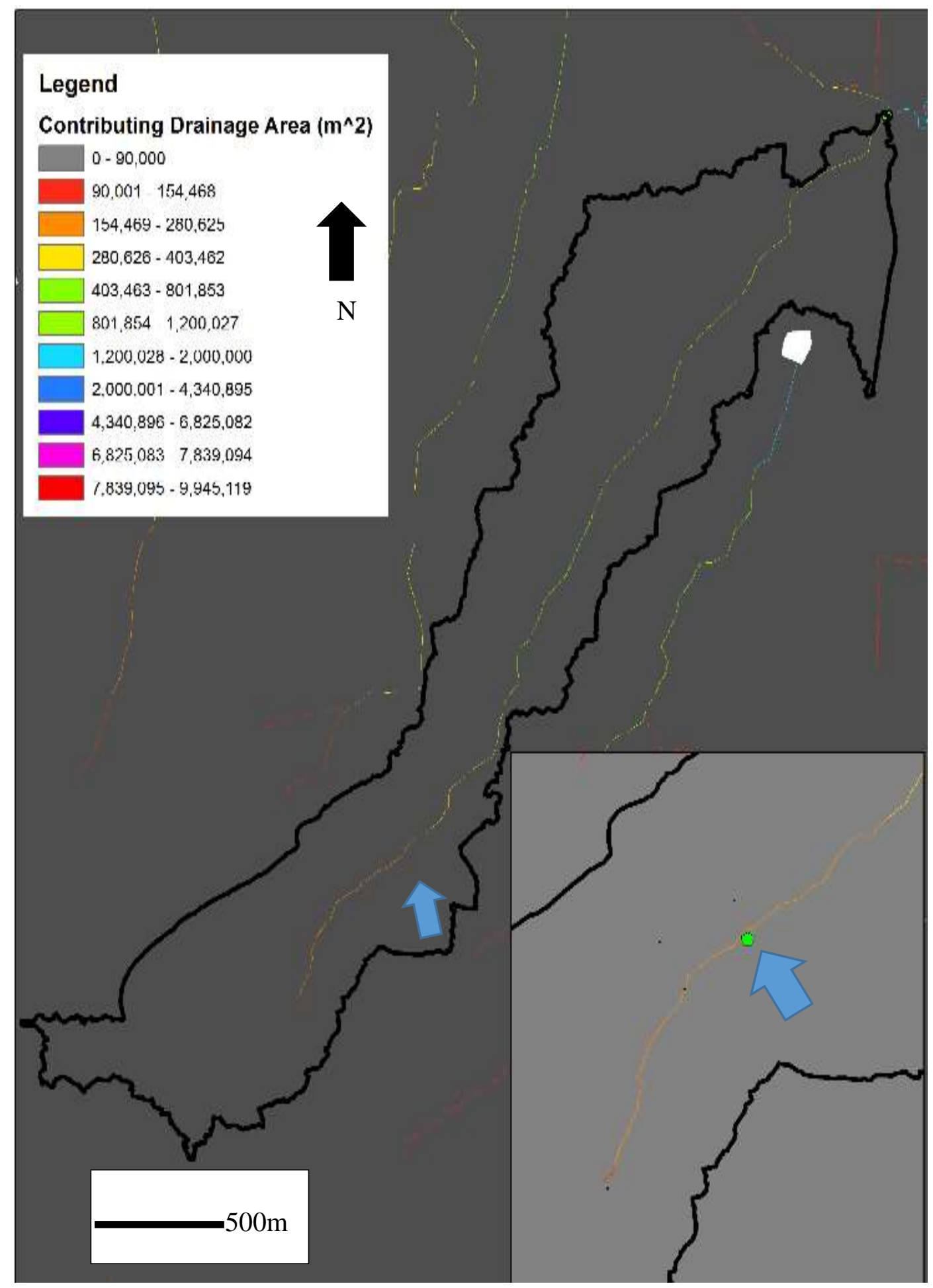

Figure 2.4 b: Drainage area map around Morningstar Creek, Site 1. Black line delineates watershed. The blue arrow indicate the same location, the erosional knickpoint on both the map and inset. 


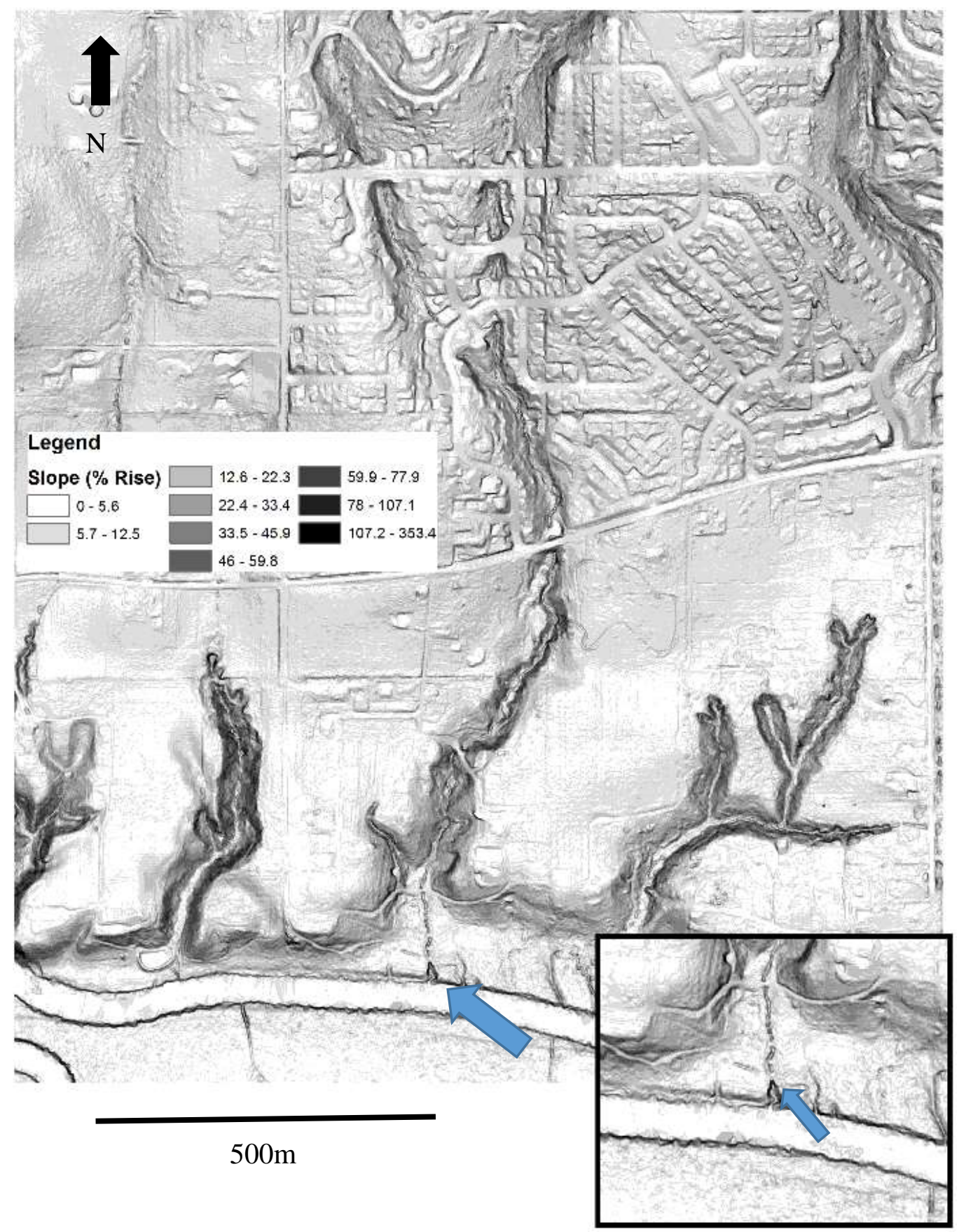

Figure 2.5a: Slope map showing percent rise around Meyers Creek, Site 2. The blue arrows indicates the same location, the erosional knickpoint on both the map and inset. 


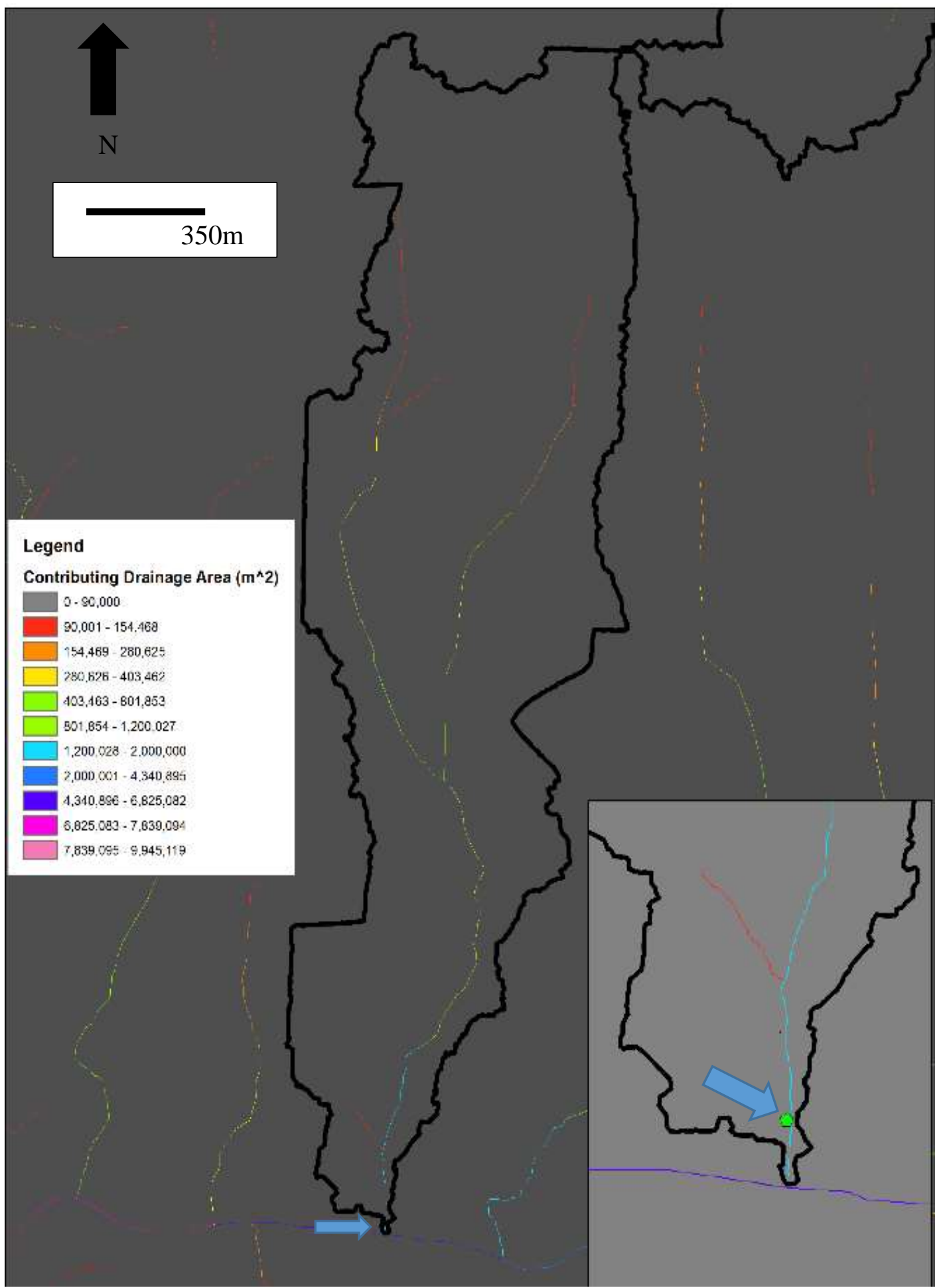

Figure 2.5 b: Drainage area map around Meyers Creek, Site 2. Black line delineates watershed. The blue arrow indicate the same location, the erosional knickpoint on both the map and inset. 


\subsection{Discussion}

The presence of unnatural features in an urban setting presents many challenges when classic geomorphic analysis is applied. Previous studies have successfully located and identified geomorphic features, such as knickpoints, from DEMs (Wobus et al., 2006; Phillips and Lutz, 2008). The urbanization of this watershed with roads, bridges, and houses affects both the physical hydrology and the way it can be analyzed. Anthropomorphic changes alter elevations and slopes, changing the way water travels over the topography (Montgomery, 1994). These alterations showed up in the DEM used for analysis, leading to artifacts on every product made from it. Knowledge of the area and aerial photographs helped me distinguish between neighborhood streets and actual channels. The Meyers Creek channel has two major spikes associated with roads that run perpendicular to the stream path, while the Morningstar Creek profile crosses many roads and other infrastructure.

A focused analysis on the two streams with large knickpoints (Fig. 2.2) revealed their commonalities and differences. Simple visual analysis and exponential regressions of channel profiles and slope and drainage area measurements at the knickpoints provided the basis to compare and contrast these channels. The Meyers Creek channel profile is much flatter than the Morningstar Creek channel. However, the regression analysis shows that the best fit lines for both have coefficients of the same order of magnitude. The profiles have a sharper curve, influenced by the topographic break at the base of Bull Mountain, the transition from hillslopes to floodplains, than the exponential regression predicts. This transition point is noticeably sharper for the profile of the Morningstar 
Creek channel. Areas with similar underlying geology should have streams with similar profiles (Hack, 1957). Here the profiles have similar geology and both contain large knickpoints, but are different in relief, overall distance, and location of the knickpoint in the channel (Table 2.1). Each stream's knickpoint occurs under different slopes and drainage areas. The Meyers Creek knickpoint is located in close proximity to its terminus under high drainage area; it is surrounded by gentle slopes and rural land use conditions relative to Morningstar Creek. The two channels that contain large knickpoints do not have uniquely common slope and drainage area characteristics. The difference in the channel profiles with large knickpoints refutes my hypothesis that channels with knickpoints would share quantifiable geometric similarities. These two channels are not especially similar to each other and, as a set, are not differentiable from the channel profiles for streams without knickpoints. They share a common erosional feature, a large knickpoint, but that cannot be directly associated with any observable common patterns in their drainage areas or slope conditions. This implies that analysis of $1 \mathrm{~m}$ resolution airborne lidar data is not sufficient to confidently identify knickpoints remotely, due to the false positives caused by anthropogenic features.

The majority of the areal extent of Bull Mountain is effectively one large hillslope, but the erosion documented in this study at the Morningstar knickpoint happened in the channel in the upper portion of the drainage basin. Before the area was urbanized infiltration was higher allowing for shallow subsurface flow, and the influence of groundwater on local creeks may have been greater (Chang, 2007). The steep slope areas surrounding this knickpoint have small accumulation areas and could contribute to 
erosion by sheetwash and soil creep. Since urbanization, infiltration has been reduced and Horton overland flow is a greater contributor to discharge in the local creeks. Currently in the majority of Morningstar Creek basin, the surrounding asphalt, stormwater routing, and housing developments have effectively helped armor the main hillslopes, and directed water to the channel only where alluvial erosion processes dominate. The occurrence of a large knickpoint is not simply revealed or explained by stream profiles and drainage area and slope conditions. A detailed examination of the knickpoint erosion through field, laboratory, and modeling investigations is discussed in the next sections. 


\section{Quantifying Knickpoint Erosion}

\subsection{Introduction}

A channel is often considered to be in one of two states: steady or transient. Steady state is a condition in which the rate of erosion of the channel bed is spatially constant, and is balanced with the rate of base level fall. A transient state describes a channel in which these rates are out of balance at one or more channel reaches, commonly due to changes in climate or tectonics (Whipple and Tucker, 1999). Transient knickpoints typically form in response to a perturbing event, such as a rapid drop in a stream's baselevel, while steady state knickpoints can result from a persistent lithological difference in the channel bed. This study focuses on transient knickpoints, which tend to migrate in the upstream direction by one or more modes.

Knickpoints exhibit common geomorphologic features (Fig. 3.1): an upper channel, knickpoint lip, knickpoint face, knickpoint base, plunge pool, side walls, and lower channel; which can all be noticed in plan view and longitudinal section. A knickpoint's physical nature and behavior are a function of the shear stress and the geologic substrate, resulting in four basic knickpoint models (Fig. 3.2) (Gardner, 1983). The first model predicts rotation through time with downstream aggradation when the lithology is uniform and nonresistant. This is common in alluvial channels where the weak sediment is transported as bed or suspended load (Dietrich et al., 2003). The second model also predicts rotation in a uniform and very resistant material, without downstream aggradation, and a small amount of sediment. The third model is parallel retreat, where vertical differences in substrate erodibility cause blocks near the face to collapse. The 
fourth model is replacement, where there is a reduction of slope and smoothing of the knickpoint lip. 


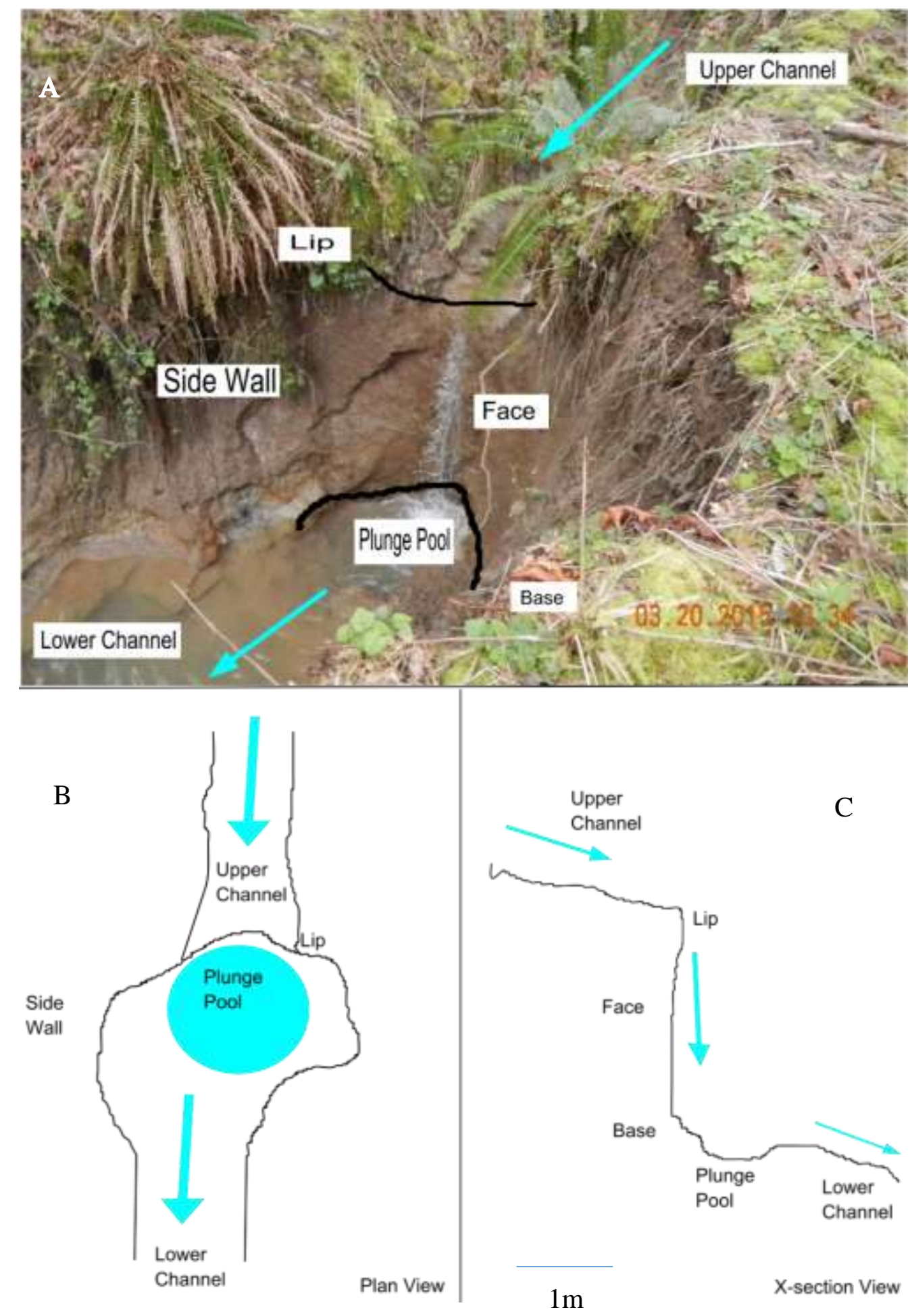

Figure 3.1: (A) Common parts of a knickpoint annotated on a photo of the Morningstar knickpoint. (B) Plan view schematic of a knickpoint. (C) Longitudinal profile view of a knickpoint. 


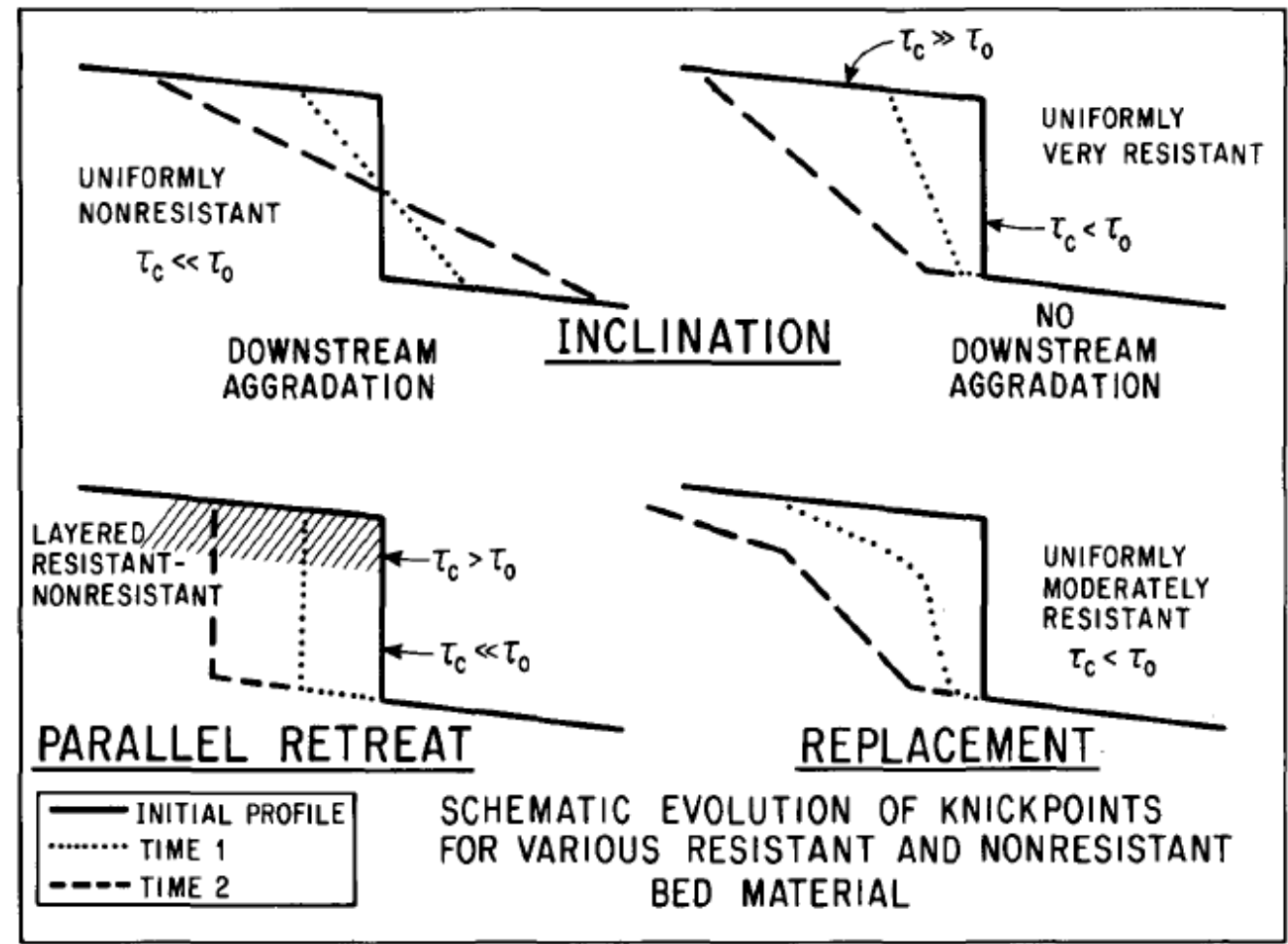

Figure 3.2: The four models of knickpoint retreat. Model three, parallel retreat, is most consistent with the erosion observed at the Morningstar knickpoint. (Gardner, 1983)

The first, second, and fourth models all predict a progressive decrease in knickpoint gradient, which is a product of the channel's transport capacity (Crosby and Whipple, 2006). The third model is the only one to predict upstream migration without a reduction in slope. The purpose of this part of the study was to determine the mode of knickpoint retreat at Morningstar Creek, and the rate at which it was occurring. I hypothesized that the knickpoints at the study sites evolved in a manner consistent with model three, with resistant layers of loess serving as the cap rock (soil) where $\tau_{\mathrm{o}}<\tau_{\mathrm{c}}$ (shear stress < critical shear stress), forming the lip of the knickpoint (Fig. 3.2, lower left panel). 


\subsection{Knickpoint Sites}

Based on the field reconnaissance of seven channels on the flanks of Bull Mountain, knickpoints with a vertical relief on the order of meters, express themselves in a minimum of two channels, Two knickpoints, in Morningstar Creek and Meyers Creek were first identified by concerned community members and the Tualatin Riverkeepers. All publicly accessible channel reaches on the north side were explored for knickpoints, but none were found of equivalent scale to those in Morningstar Creek and Meyers Creek. The southern drainages largely run through private, inaccessible properties and were not investigated. Although significant knickpoints (defined here as at least meters in width and height) are rare. The mix of geology, historic changes in land use, and discharge regimes at the study site are not locally unique; they are present throughout the lower Willamette Valley.

The knickpoint in Morningstar Creek on the north side of Bull Mountain was the subject of the detailed point cloud investigation. The headwaters of the creek begin at 166 m elevation and run down for $2.18 \mathrm{~km}$ where they meet Fanno Creek, a tributary of the Tualatin River. The knickpoint is located $1.84 \mathrm{~km}$ upstream from Fanno Creek, at an elevation of $126 \mathrm{~m}$. The second large knickpoint is on the southern side of Bull Mountain, $36 \mathrm{~m}$ from the mouth of Meyers Creek along the banks of the Tualatin River. This knickpoint is inset into a flat floodplain bench, rather than a valley. The channels in the area are primarily fed by stormwater runoff. The USGS classified the area around Fanno Creek at nearby Durham as being $84 \%$ urban with a mean impervious surface of 39\% (Waite et al., 2008). 
The initial reconnaissance of the Morningstar drainage, on 3/20/2015, revealed a creek running SW to NE in the bottom of a $300 \mathrm{~m}$ wide valley, flanked on either side by single family residences, with lots extending onto the side slopes to the northwest and southeast. At the top of the valley, the channel head of the creek starts at a series of manmade stormwater outlets (Fig. 3.3) that are the primary source of discharge. I followed the path of the creek as it travels down the valley and observed steep banks and a relatively narrow channel width of $\sim 2 \mathrm{~m}$. The typical depth of channel directly above the knickpoint was estimated to be $\sim 2 \mathrm{~m}$. The Morningstar Creek knickpoint (Fig 3.4, photographed during this initial visit) had a vertical relief of $\sim 2 \mathrm{~m}$, between the upper channel and the plunge pool. I observed a thin mantle of organic-rich topsoil overlying an extensive (both vertically and horizontally) fine grained, compact, and cohesive medium brown soil with some orange staining/mottles. This material was identified as loess in the field and was observed as the continuous substrate of the channel above and below the knickpoint. Immediately below the knickpoint, downstream from the plunge pool, the channel widens to $\sim 10 \mathrm{~m}$ and deepens to $\sim 3 \mathrm{~m}$ (Fig. 3.5). Farther downstream $(\sim 50 \mathrm{~m})$ the channel narrows back to about $2 \mathrm{~m}$ in width but remains $\sim 3 \mathrm{~m}$ deep. The channel then shallows to less than $1 \mathrm{~m}$ deep and widens before going under a road through a culvert. Although small (less than $0.5 \mathrm{~m}$ high) ‘stair step' features were commonly found (Fig. 3.6) in neighboring drainages of similar size, substrate type, and flow regimes, no other large knickpoints were observed on the north side of Bull Mountain. Exposed intact bedrock (basalt) was not found in the Morningstar drainage. Small cobbles of basalt were observed in the channel but these were noted as float, originating from construction. In 
just one neighboring drainage to the east was basalt of any extent observed. There, I observed highly weathered basalt bedrock overlain by basalt cobbles. That substrate lines the creek in the lower portion before transitioning into loess farther upstream (Fig. 3.7).

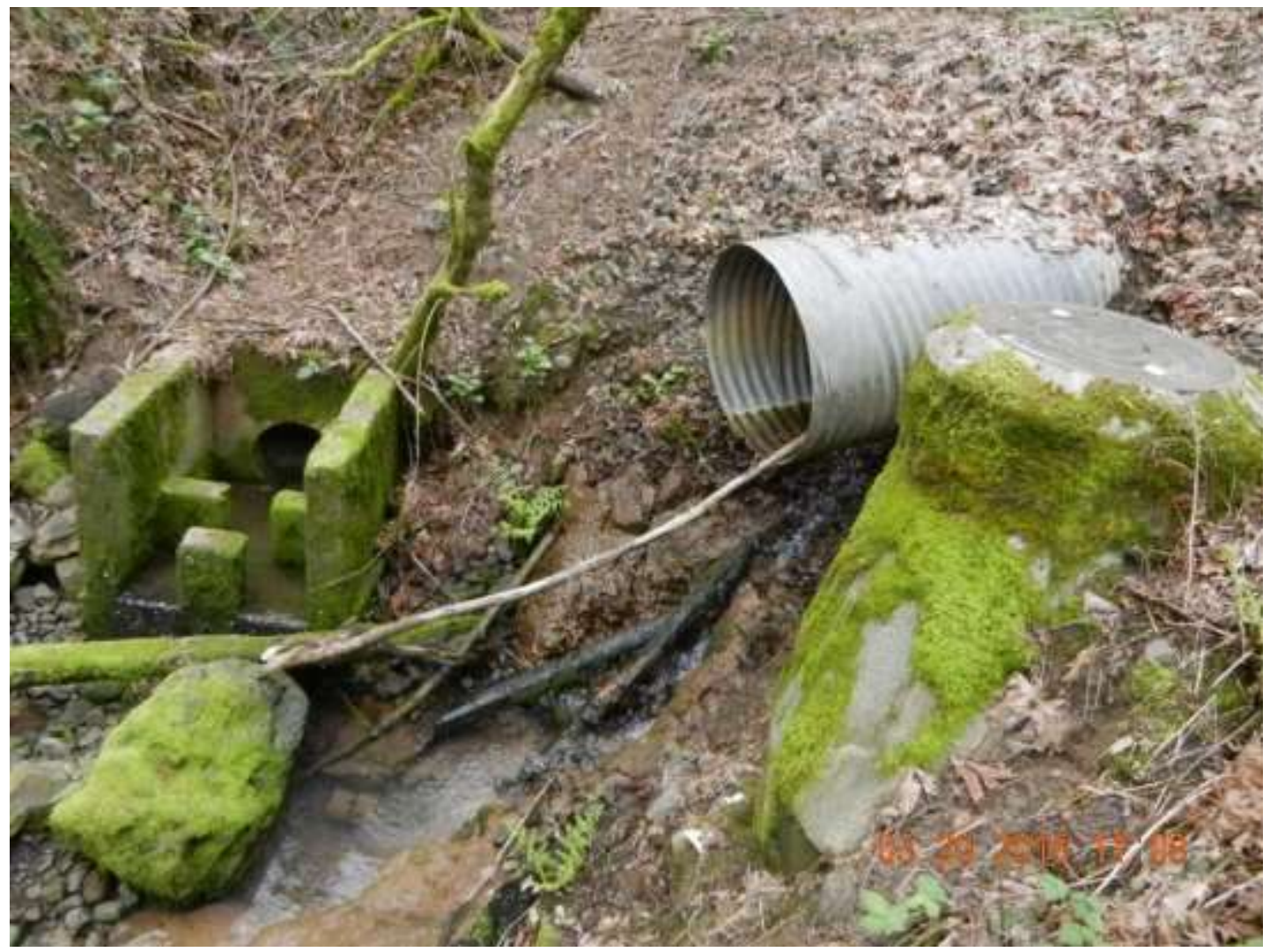

Figure 3.3: The headwaters of Morningstar Creek feature a large corrugated metal pipe and a concrete energy dissipator in front of a smaller second outflow pipe. Stormwater from the surrounding neighborhood is the source of this discharge. 


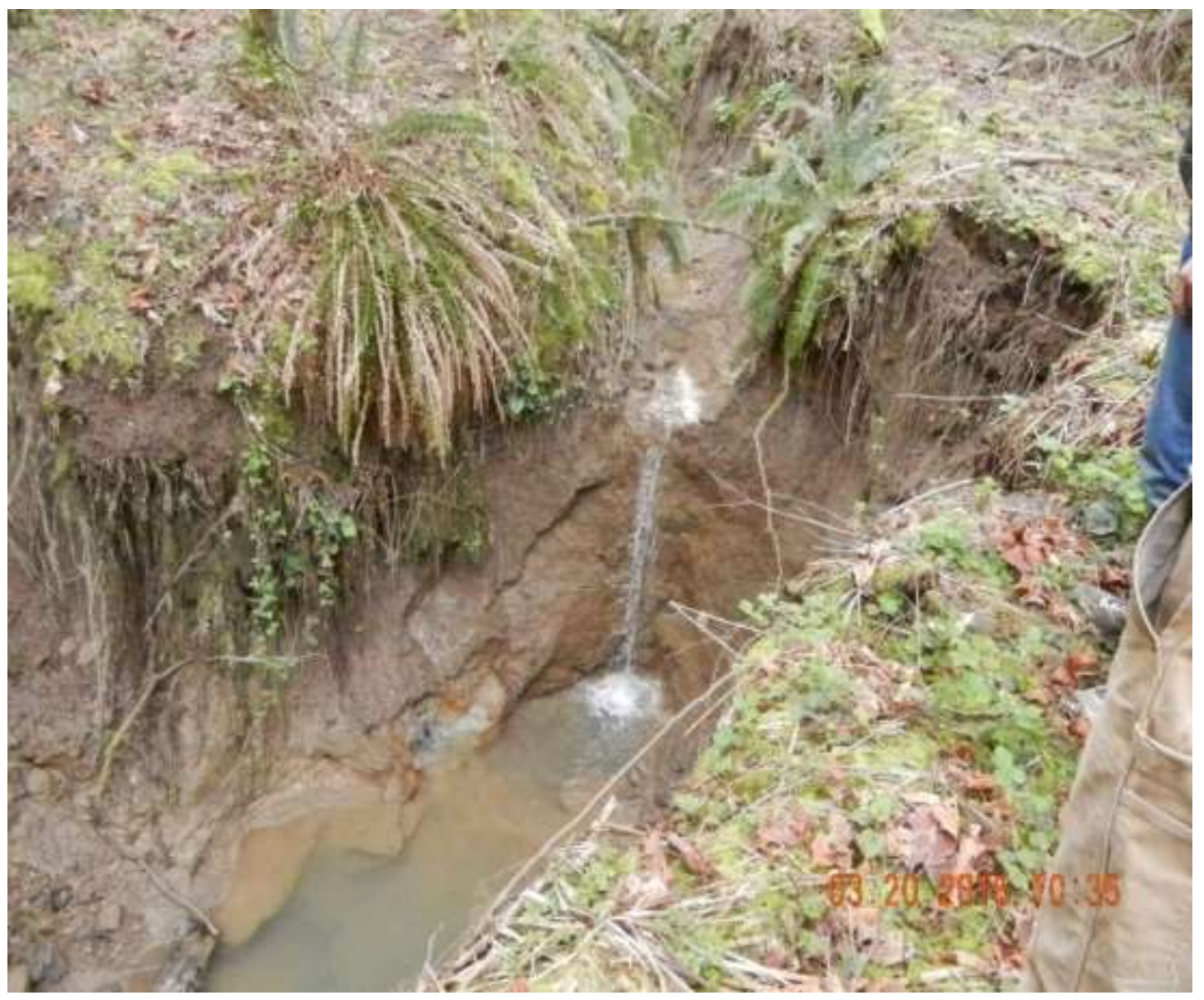

Figure 3.4: The Morningstar knickpoint, as it appeared during initial site reconnaissance on $3 / 20 / 2015$. This view is looking upstream. Some orange staining appears in the center of the image at the base of the lower channel. 


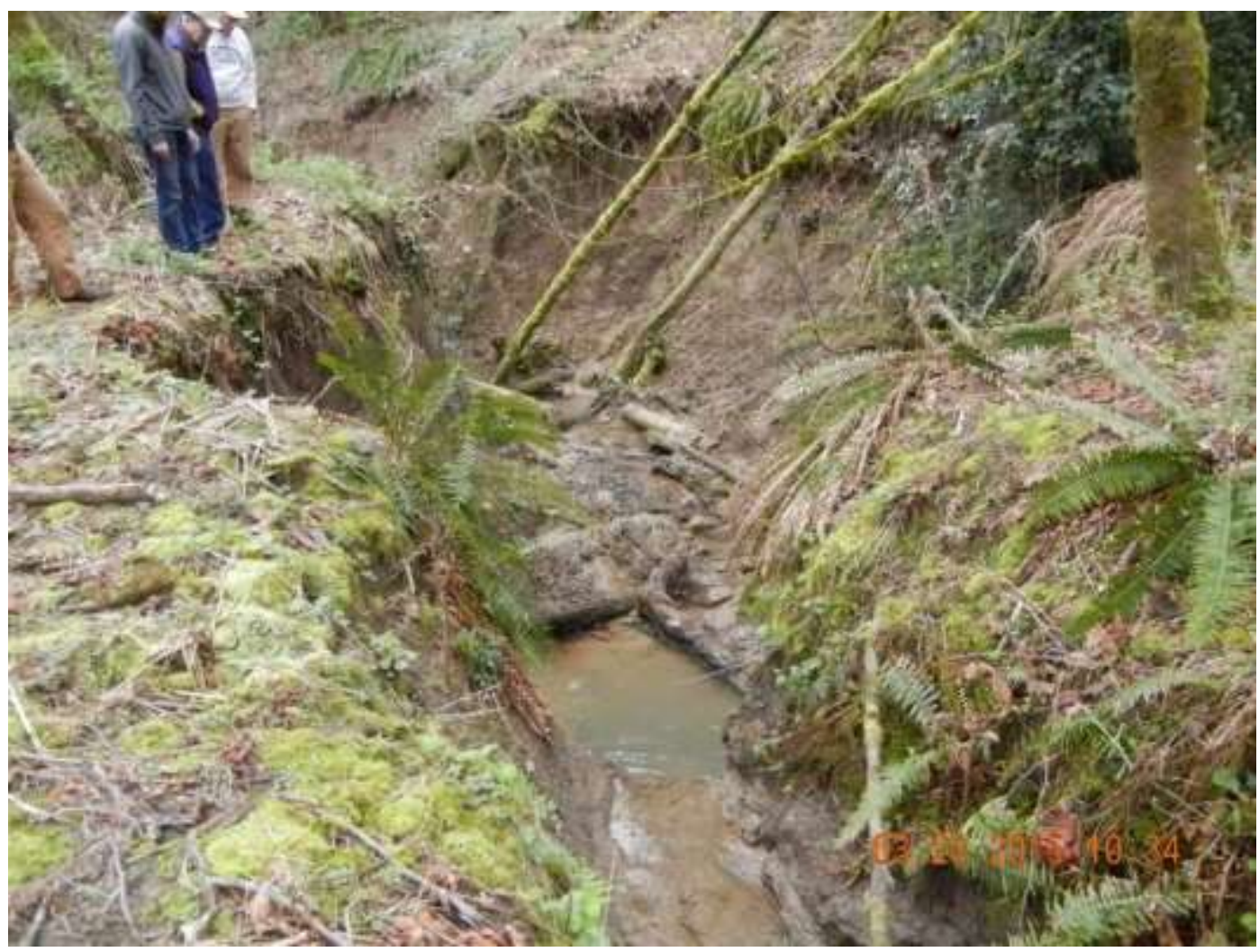

Figure 3.5: The lower channel directly below Morningstar knickpoint, as it appeared during initial site reconnaissance on $3 / 20 / 2015$. This view is downstream. The lower channel beyond the plunge pool is wider and deeper than the upper channel, suggesting that the knickpoint may have migrated upstream through this reach prior to this study. 


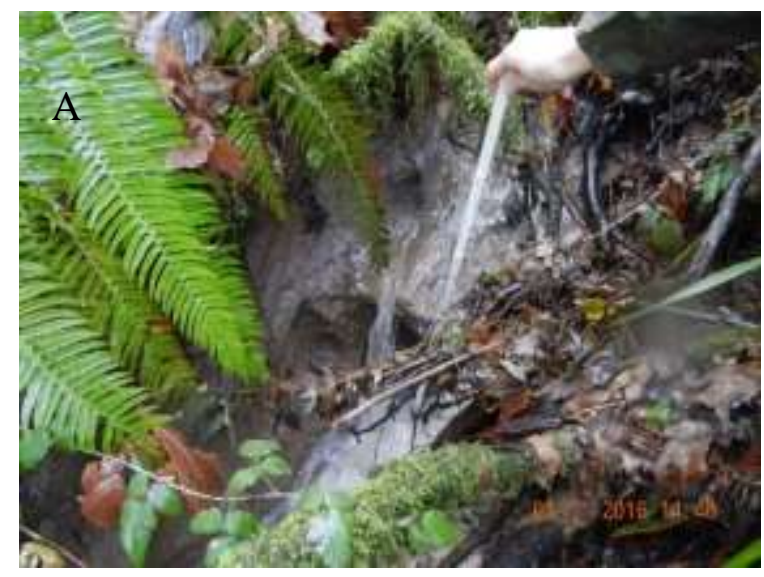

$\mathrm{B}$
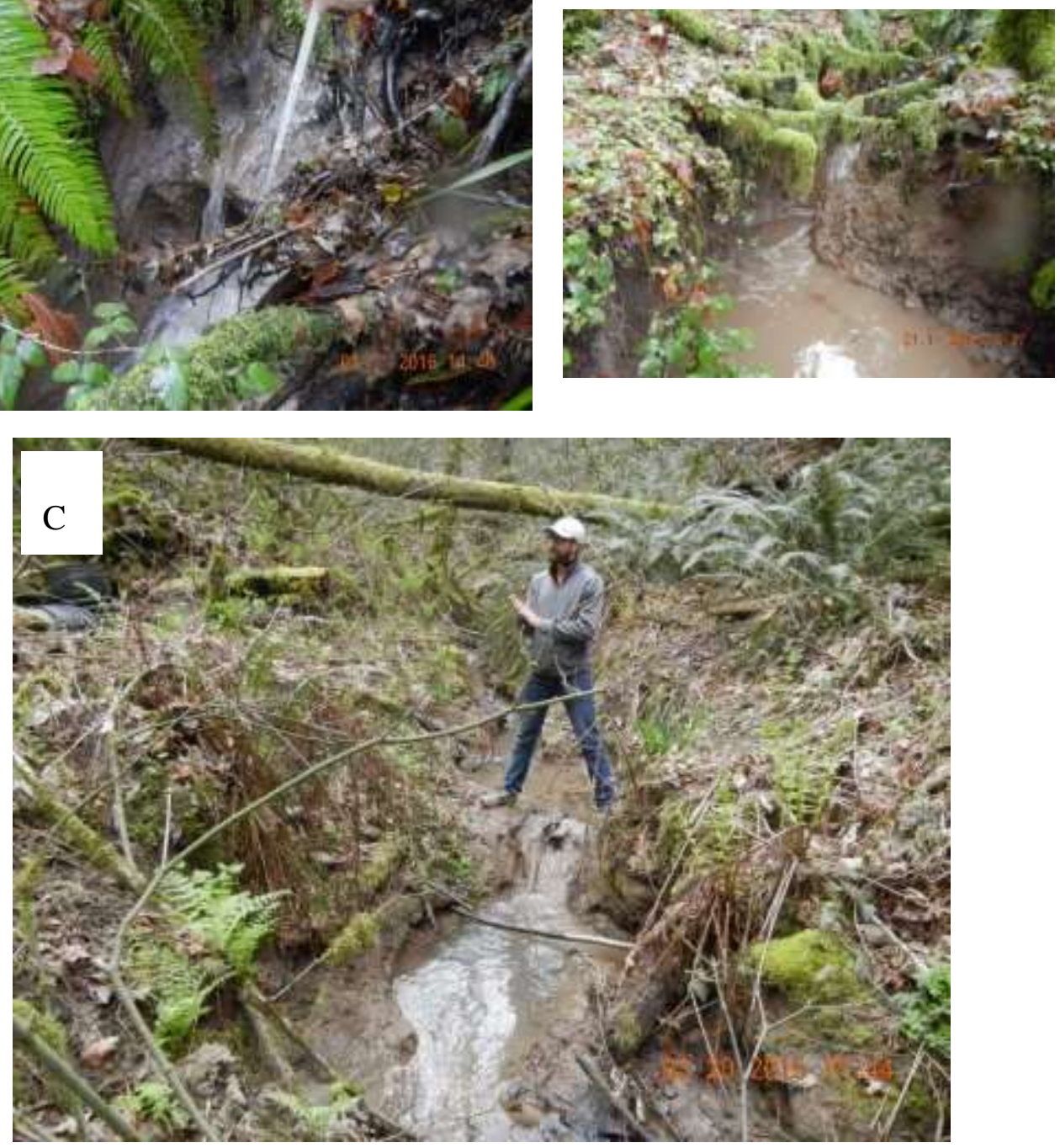

Figure 3.6: (A) and (B) Two views of a small knickpoint/stair step features in a drainage west of Morningstar creek. (C) A different stair step feature in a different drainage west of Morningstar Creek. 

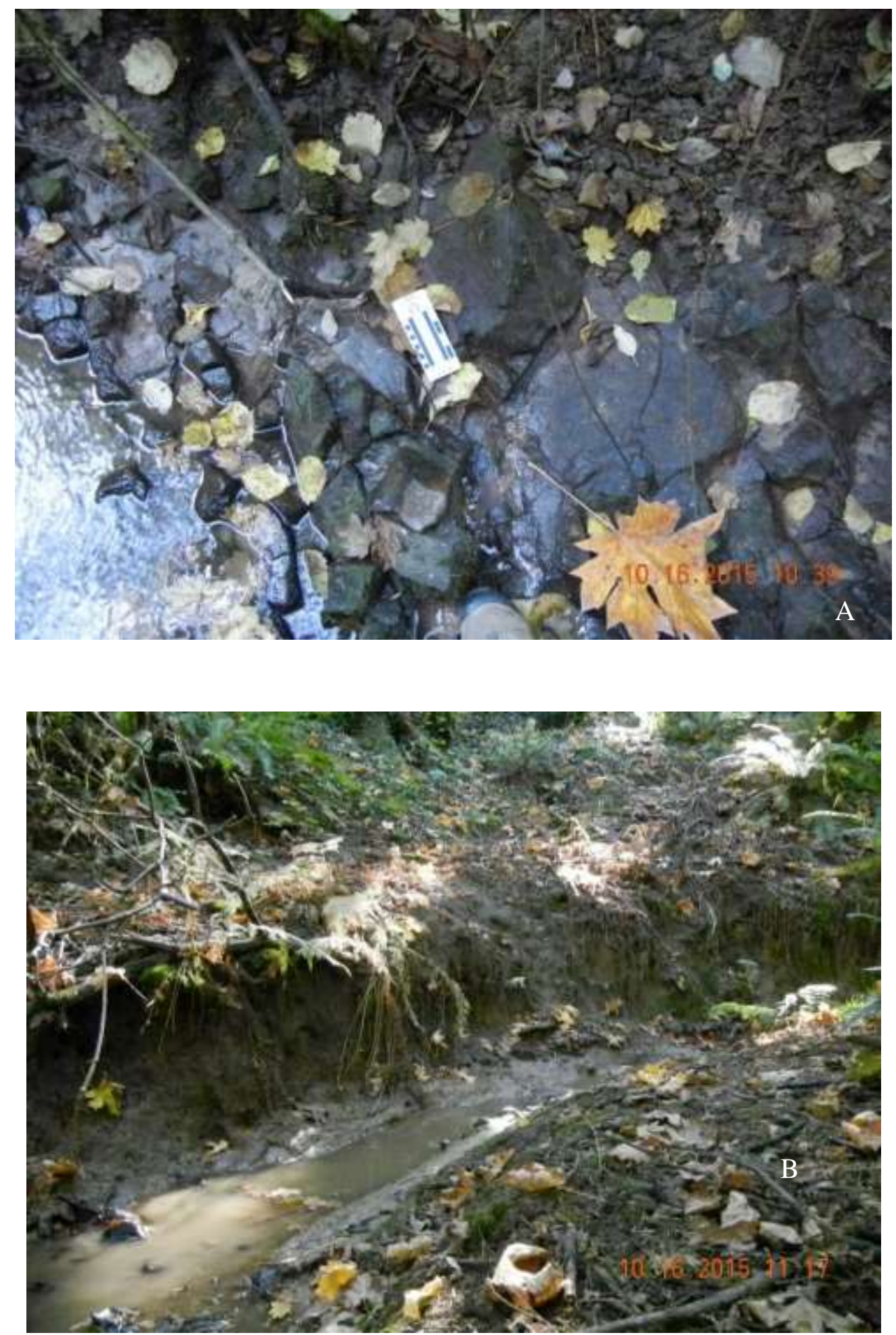

Figure 3.7: (A) Intact basalt (bedrock) at the base of a drainage east of Morningstar Creek. (B) The same creek farther upstream where the basalt is covered with loess. 


\subsection{Methods: Data Collection}

To quantify the changes taking place in the channel I applied TLS and SfM technology, both tools that capture high resolution 3D scans of the topography, producing a point cloud that can be analyzed for topographic changes. I differenced multi-interval scans of the Morningstar Creek knickpoint site to produce a high resolution map of the spatial pattern of erosion, and a precise estimate of the volume of material eroded. During the initial visit, a workflow for TLS collection was thought out, but evolved throughout the investigation to maximize efficacy and precision.

I used TLS and SfM to collect and produce five point cloud scenes that each recorded the topography of the knickpoint and channel. Each TLS point cloud scene is the product of multiple individual TLS scans aligned and merged together. The SfM produced point cloud relied on processing over 400 digital photographs through software to reconstruct the 3D surface. From these five point clouds I created ten interval pairs to difference.

Each of these pairs were first aligned using reference points that remained stable and then analyzed to reveal the erosional changes that occurred during that interval. I used a point - to - point differencing technique to visualize the spatial pattern of upstream retreat and a rasterized surface - to - surface differencing technique to measure volumes of eroded material for each interval pair. For a detailed explanation of the tools, techniques, and error quantification applied here, see Appendix A.

After completing the scenes during the 2015 - 2016 water year, several abnormally large winter storms occurred during winter 2016 - 2017, and the knickpoint 
was revisited on 4/9/2017. Based on reference points, I observed that the knickpoint retreated beyond the extent of all previous scans. I therefore documented the changes with photographs and recorded the distance of retreat with a tape measure as shown in Figure 3.8. I used natural features in and around the channel as references points to make this manual measurment (Fig. 3.9). These traditional visual observations and measurements of knickpoint erosion, along with the TLS methodology described above, yield a complete record of how the landscape at this site changed over the course of one full water year plus the following winter.

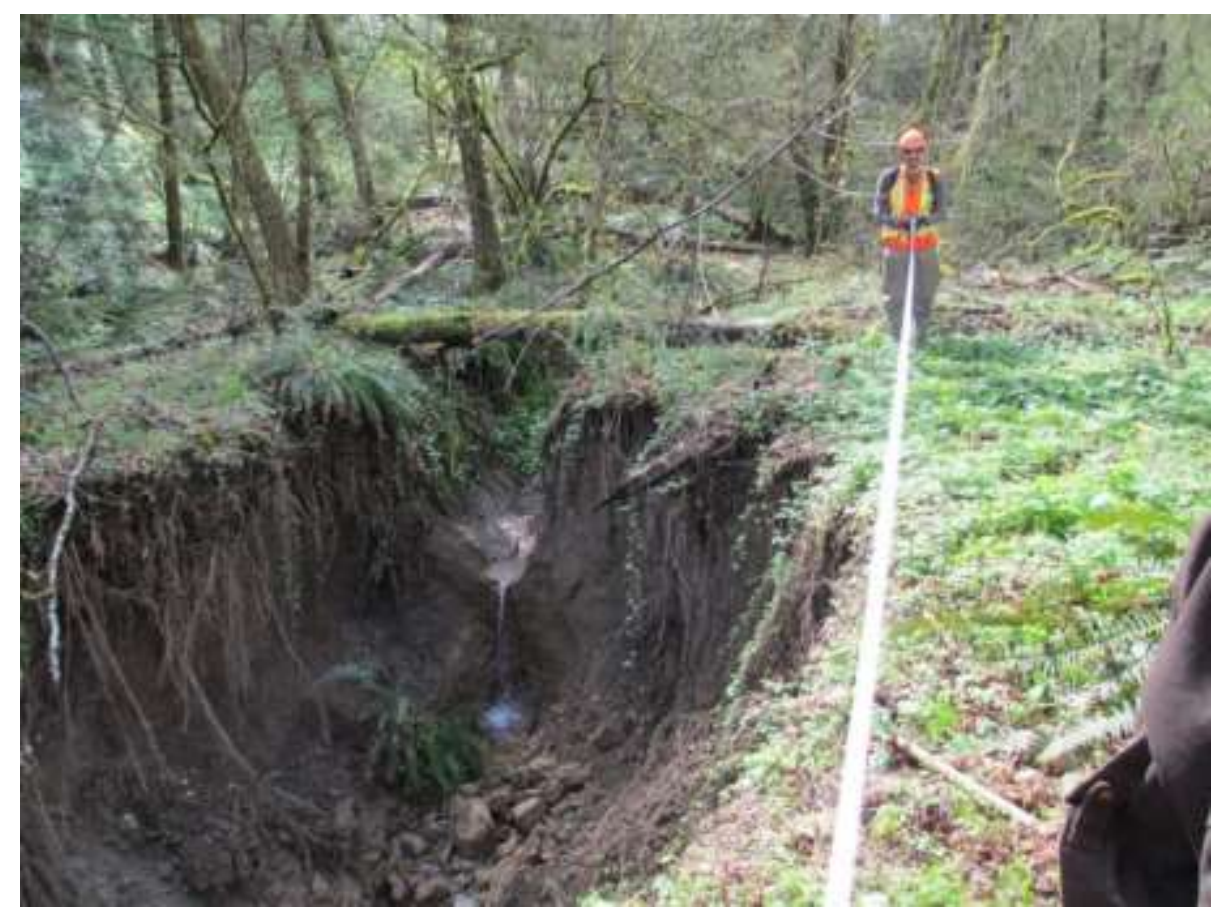

Figure 3.8: Measuring the upstream retreat $(12.5 \mathrm{~m})$ of the Morningstar knickpoint between 11/18/2016 and 4/9/2017. This was done using a measuring tape and known reference points. 


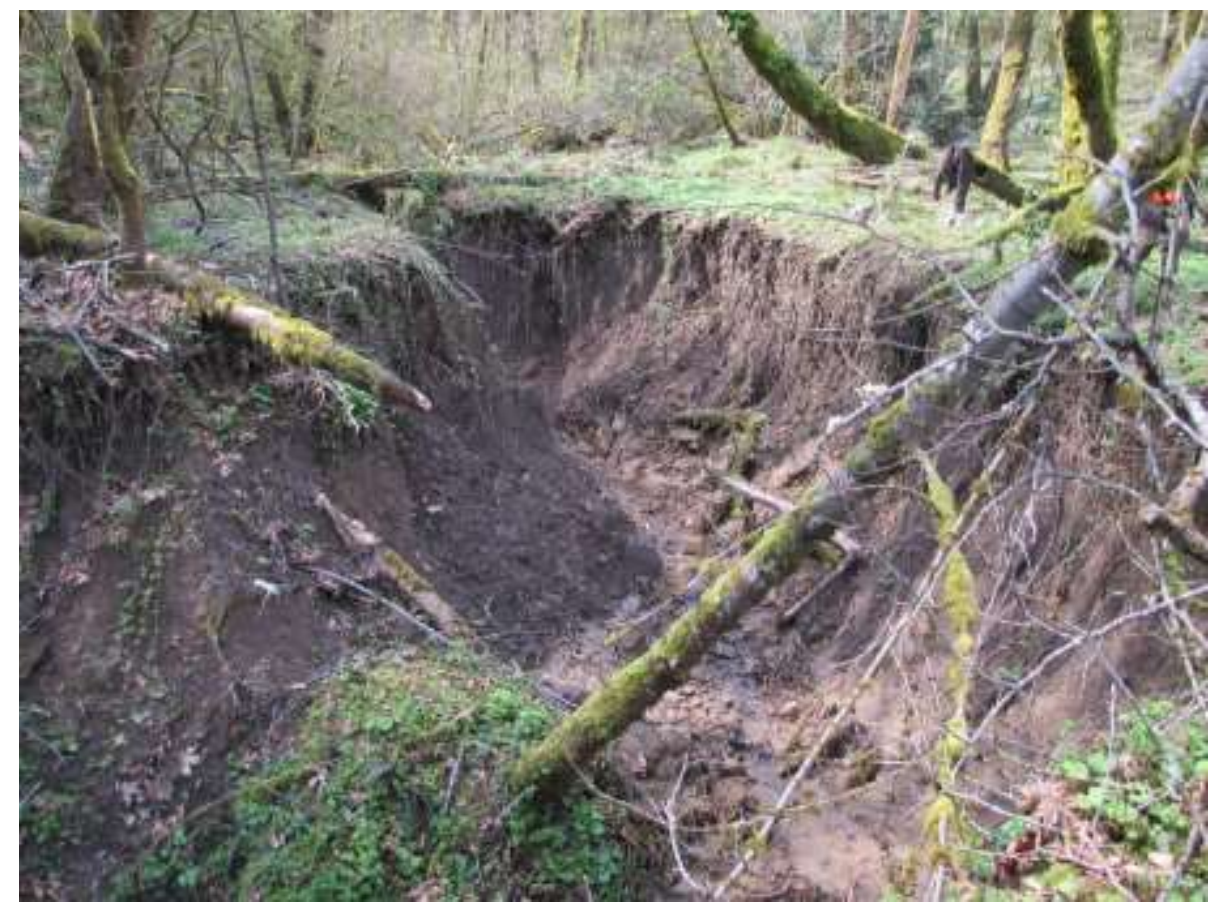

Figure 3.9: An upstream view of the knickpoint and lower channel on 4/9/2017. In the foreground the collapsed rootball and in the background the fallen log across the upper the channel were used as natural reference point for the manual retreat measurements.

To connect observed erosion to observed correlative climatic conditions, I used precipitation data from a nearby USGS weather station (Sylvania PCC Rain Gage SS Bldg, 12000 SW. 49th Ave.) located on the TRB side of the Tualatin Mountains. I processed these data to produce the following four precipitation metrics for comparison:

The first precipitation metric is total precipitation that occurred between each interval pair. This was chosen to examine the correlation between erosion rate and cumulative precipitation. I hypothesized that as the total amount of precipitation between interval pairs increased, there would be an increase in erosion rate.

The second precipitation metric is the number of wetting and drying cycles that occurred between the interval pairs. This was produced through visual observation and 
counting the number of peaks (large individual rain events that appear as spikes) above a base level of $\sim 0.0075 \mathrm{~m} /$ day on the graph of the precipitation data over the interval pair. My hypothesis was that the number of wetting and drying cycles is correlated to the erosion rate due to the exfoliation sheet failure mode of erosion observed. Exfoliation sheet failure occurs when a weak plane parallel to the orientation of the knickpoint face or channel wall, $\sim 3 \mathrm{~cm}$ deep, causes a large thin pane of material to flake off; a noticeable scarp at the margin of the sheet failure may remain (Selander, 2004).

The third precipitation metric was average precipitation rate $(\mathrm{m} / \mathrm{yr})$, calculated by taking the quotient of the total precipitation between each interval pair and the time span. This average precipitation rate was compared to the average erosion rate and their relationship was analyzed. My hypothesis was that, as average precipitation rate increased, there would be a corresponding increase in average erosion rate.

The fourth precipitation metric was the percentage of days between the interval pairs in which a precipitation event greater than $0.015 \mathrm{~m}$ occurred. The amount of rainfall during these intense storms was hypothesized to be most closely linked to the average retreat rate.

The point cloud derived retreat rate data were plotted and regressed using a linear model against all precipitation metric data, then a second set of regressions was carried out including the extreme event data measured manually. This enabled all of my hypotheses to be tested using both normal erosion conditions and including extreme erosion conditions. Linear relationships between the precipitation metric and retreat rate 
were considered significant if the confidence that the slope of the regression differed from zero was equal to or greater than $95 \%$.

\subsection{Observations and Results}

\subsubsection{Patterns of Erosion}

Four primary mechanisms of erosion at knickpoint faces were observed and recorded as drivers of its retreat. The first mechanism is the calving of isolated and intact blocks of loess from the face into the plunge pool, as shown in Figure 3.10. The second mode is exfoliation, described as the flaking of thin sheets of material (Selander, 2004). Figure 3.11 shows visible scarps on the knickpoint face that indicate the margins where this sheet failure has occurred. The third mode of erosion is the undercutting of the knickpoint base, and the carving out of the face at the rear of the plunge pool (Fig. 3.12). The fourth mode of erosion is upper bank failure, where portions of the bank become unstable and collapse into the lower channel as the knickpoint face retreats (Fig. 3.11). These modes were observed to occur with various amounts of dominance, in and out of combination over the course of the investigation. Below, I summarize the mechanisms, volumes, and spatial patterns of knickpoint erosion for each time interval in sequential order. 


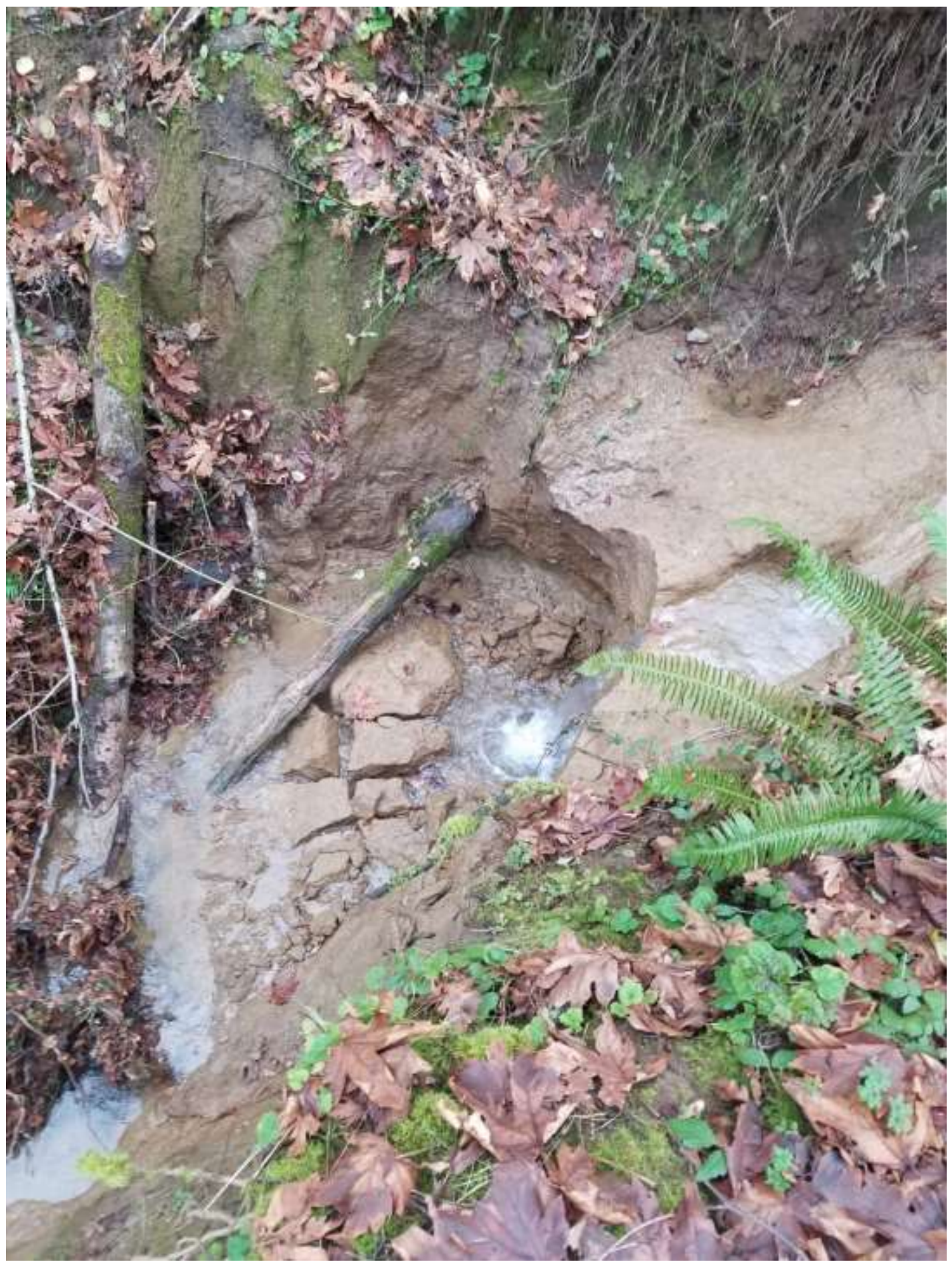

Figure 3.10: A top-down view of the knickpoint face (11/18/2016). Note the presence of multiple failed blocks of loess in the plunge pool area at the base of the knickpoint. 


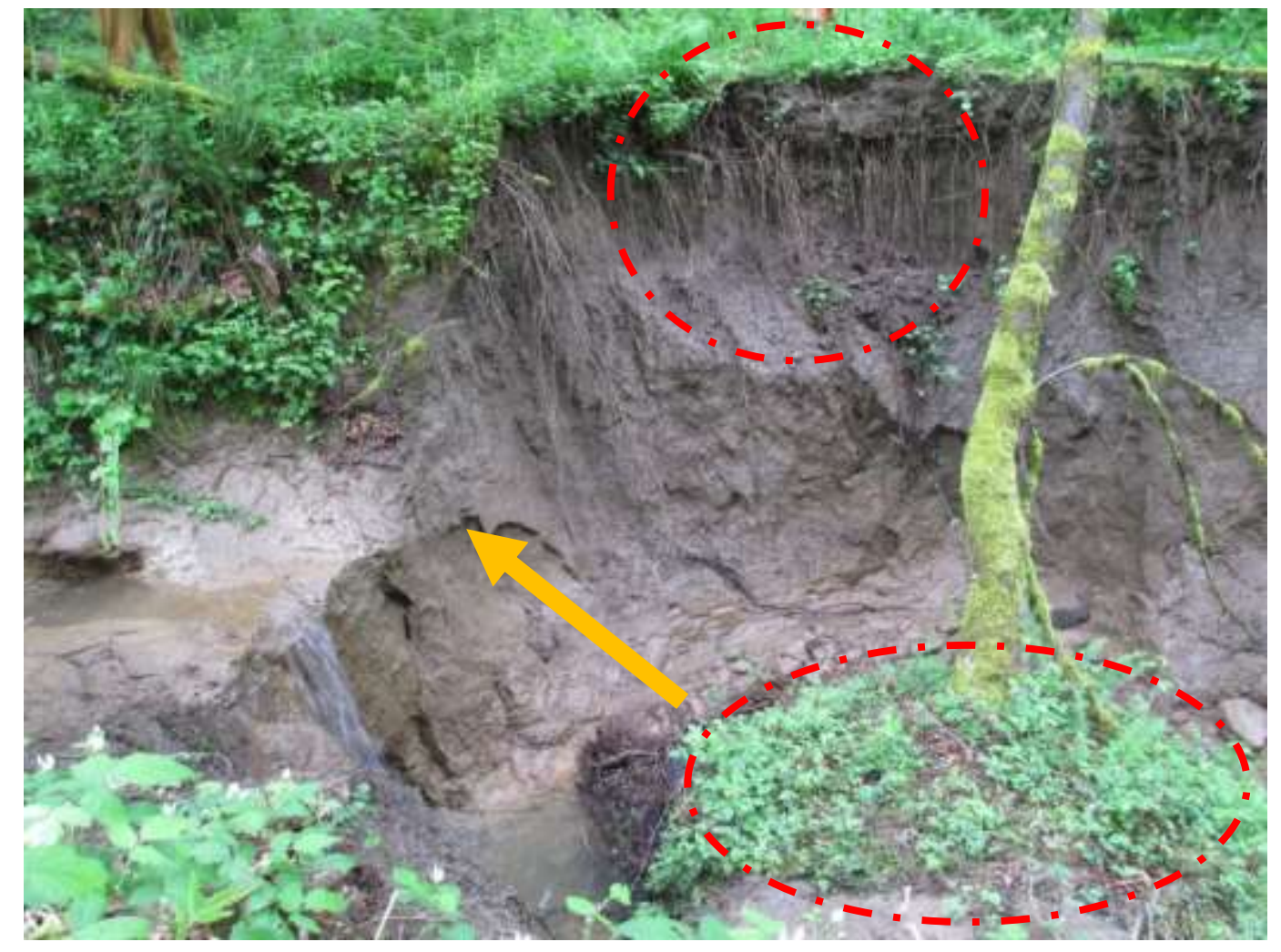

Figure 3.11: The knickpoint face showing evidence of sheet failure due to exfoliation. Yellow arrow indicates the margin of this exfoliation (4/29/2016). The dashed red circles highlights upper bank failure. 


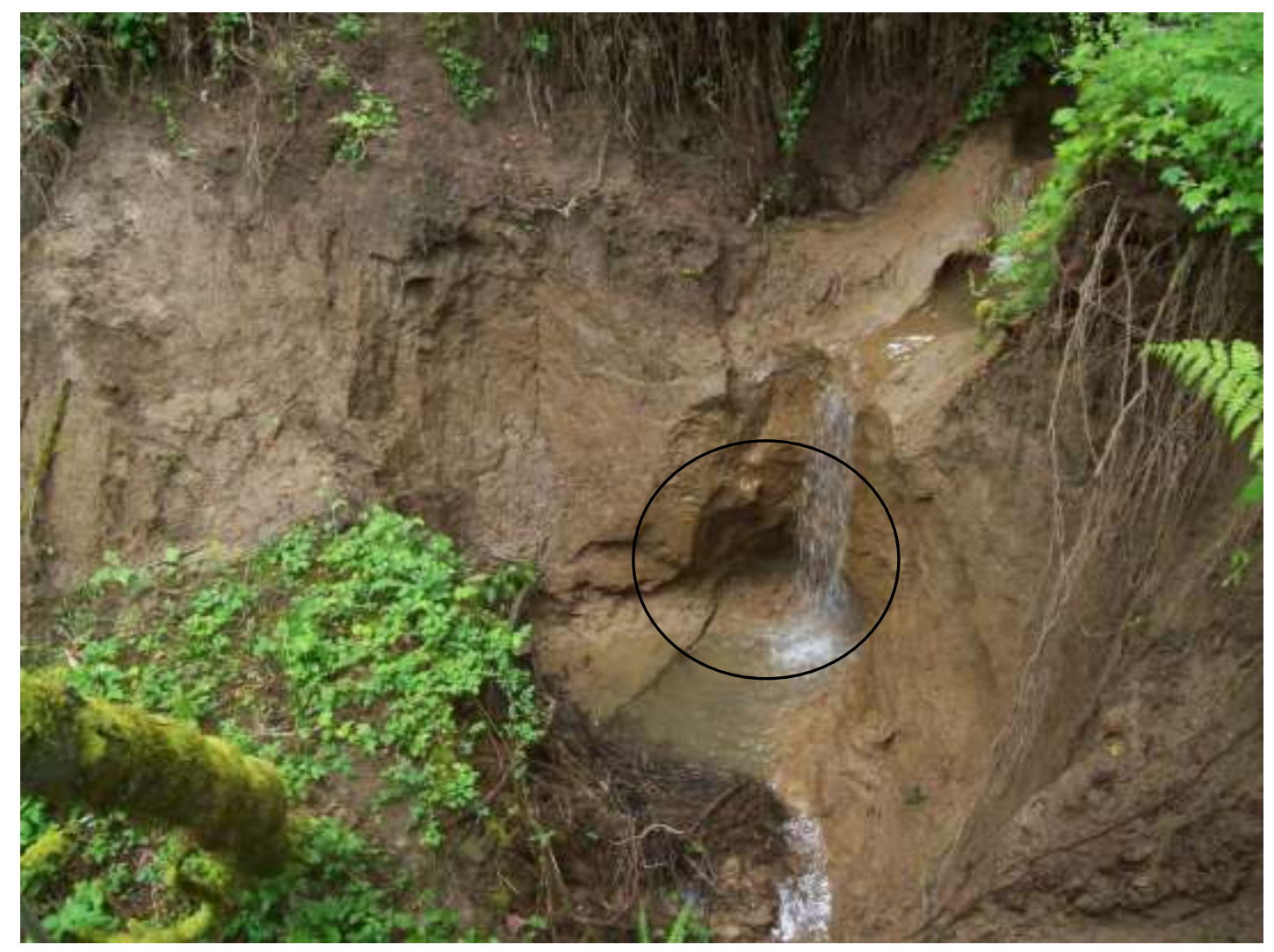

Figure 3.12: A view of the knickpoint face highlighting (black circle) the area where undercutting was observed on 4/29/2016.

For the first time period of the study, between $8 / 19 / 2015$ and $10 / 23 / 2015$, the visual pattern of erosion, based on point to point distance differencing, is shown in Figure 3.13a. The areas of blue and blue-green, across the majority of the knickpoint face indicate a difference of $\sim 4 \mathrm{~cm}$, which exceeds the minimum detectable difference (MDD) of $1 \mathrm{~cm}$. The mode of erosion here is attributed to exfoliation. Green areas indicate a larger difference (of $\sim 11 \mathrm{~cm}$ ) which I attributed to the block failure mechanism. Figure $3.13 \mathrm{~b}$ shows the relative difference in the upstream direction for each grid cell across the knickpoint face determined from raster surface - to - surface 
differencing; the uniform green color corresponds to a range of upstream erosion between 0.3 and $0.07 \mathrm{~m}$. Total volume of erosion was $-0.19 \mathrm{~m}^{3}$ across the $4.68 \mathrm{~m}^{2}$ surface area of the face (Table 3.1). Here and in the following results a negative value indicates erosion in the upstream direction and a positive value indicates deposition. This applies to the raster surface - to - surface differencing only because the point to point differencing just records the magnitude of change, not the sign. The average amount of upstream retreat for this period was $-0.04 \mathrm{~m}$, as shown in Table 3.1. 


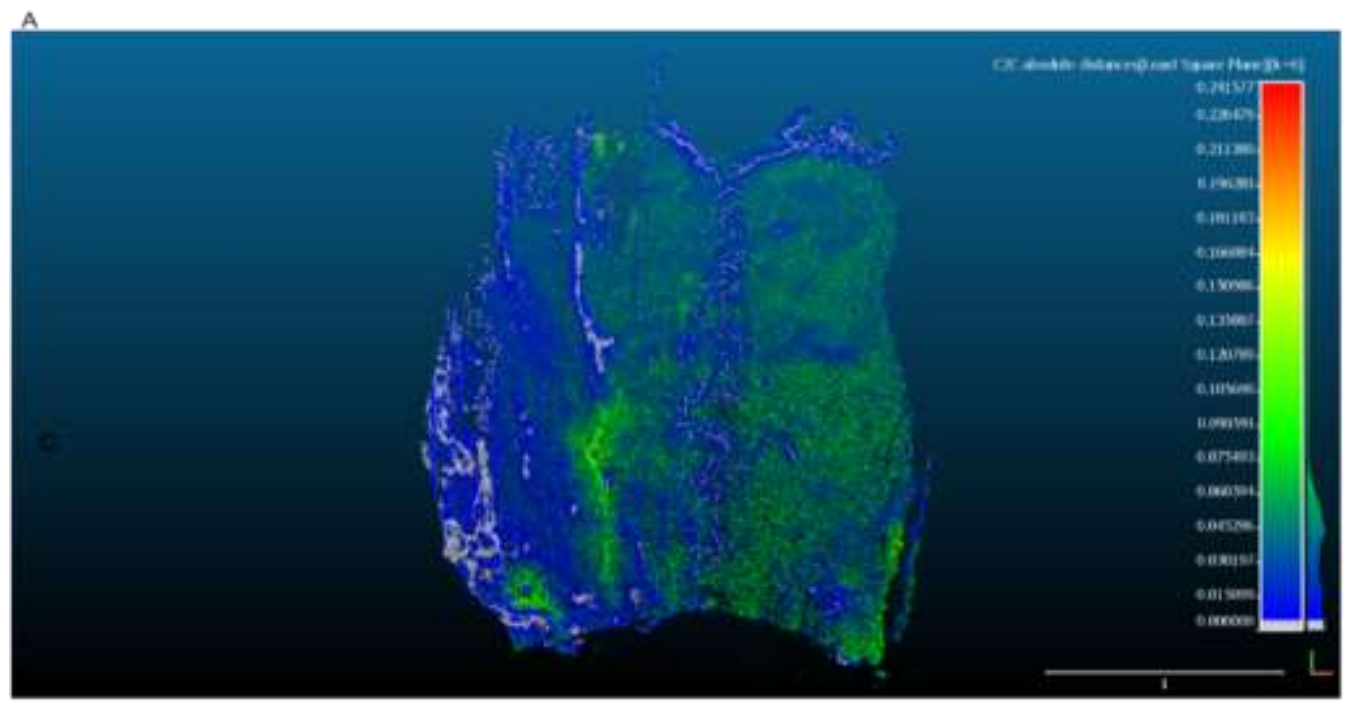

B

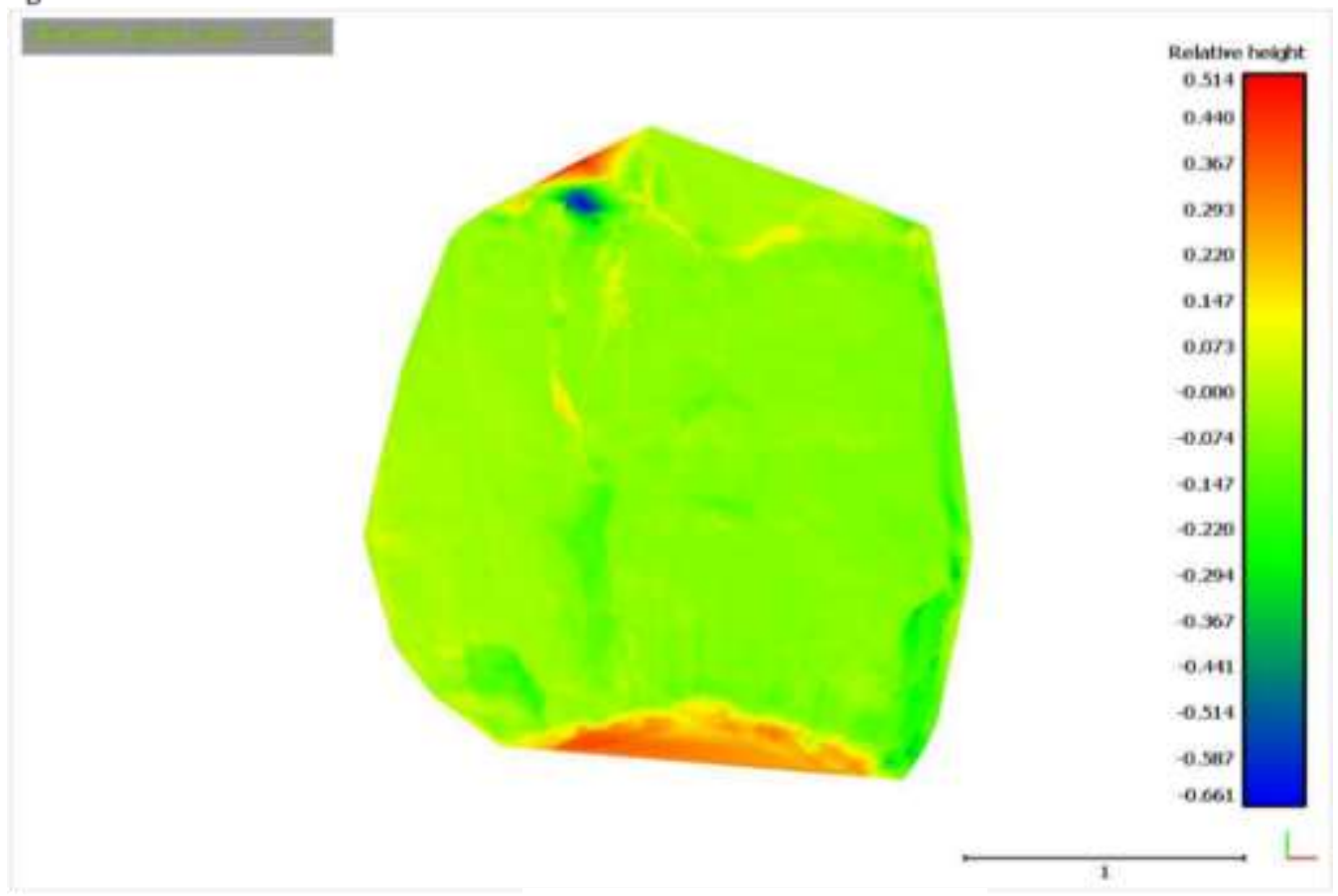

$8 / 19 / 2015-10 / 23 / 2015$

Figure 3.13: (A) Shows the pattern and distribution of minimum point to point distances between the knickpoint face on 8/19/2015 and 10/23/2015. The color scale starts (blue) at the minimum detectable difference and saturates (red) at the maximum point distance. Histogram to the right of this color bar shows the relative frequency of point to point difference. All scales are in meters. (B) Shows a choropleth map of the change in horizontal distance of the knickpoint face (referred to as the change in height because of a $90^{\circ}$ rotation applied to the rasterized point clouds) between 8/20/2015 and 10/23/2015. (The color scale and methodology explanations apply to all subsequent point cloud difference figures here as well as in Appendix A) 


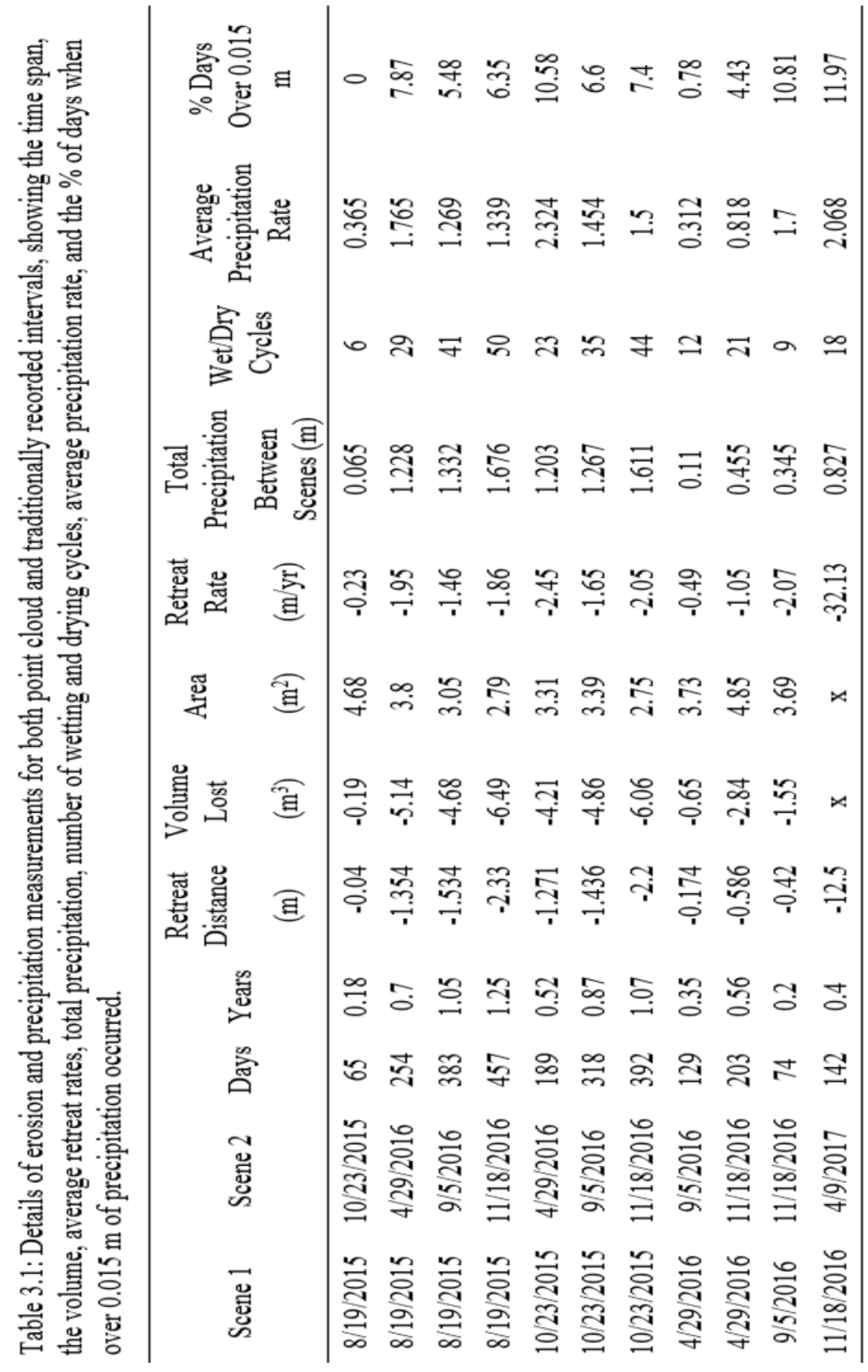


For the second time period, Figure 3.14a shows the point to point distance map between 10/23/2015 and 4/29/2016, the latter of which was produced from SfM. This visual pattern of erosion reveals a somewhat uniform distribution of distances centered on $1.09 \mathrm{~m}$, which far exceeds the MDD of $0.03 \mathrm{~m}$. Ridge like seams defining the margins of exfoliation sheets and block failures are evident to the left and right of center. The undercutting of the plunge pool is indicated by the largest difference in distance (areas of red) at $1.72 \mathrm{~m}$. The map of volume change per area of each cell, Figure $3.14 \mathrm{~b}$, shows the areas of undercutting at the left side of the base as the largest erosion of $2.07 \mathrm{~m}$ to $2.30 \mathrm{~m}$. Rasterized surface to surface measurements (Fig. 3.14b) require distances to be horizontal in the upstream direction while point to point measurements (Fig. 3.14a) just rely on the distance to the nearest point regardless of direction; this distinction explains the discrepancy of $\sim 0.58 \mathrm{~m}$. The TLS instrument and the cameras used in SfM require direct line of sight to record a high density of point measurements. The right side of the base of the knickpoint face, in red to orange, is where the smallest erosion, $0.04 \mathrm{~m}$ to 0.91 $\mathrm{m}$ was measured. Note that all values are negative in this time interval indicating no areas of the knickpoint remained stable. Total volume of erosion was $-4.21 \mathrm{~m}^{3}$ across the 3.31 $\mathrm{m}^{2}$ surface area of the face (Table 3.1), resulting in the average amount of upstream retreat for this period of $-1.27 \mathrm{~m}$ as shown in Table 3.1 . 


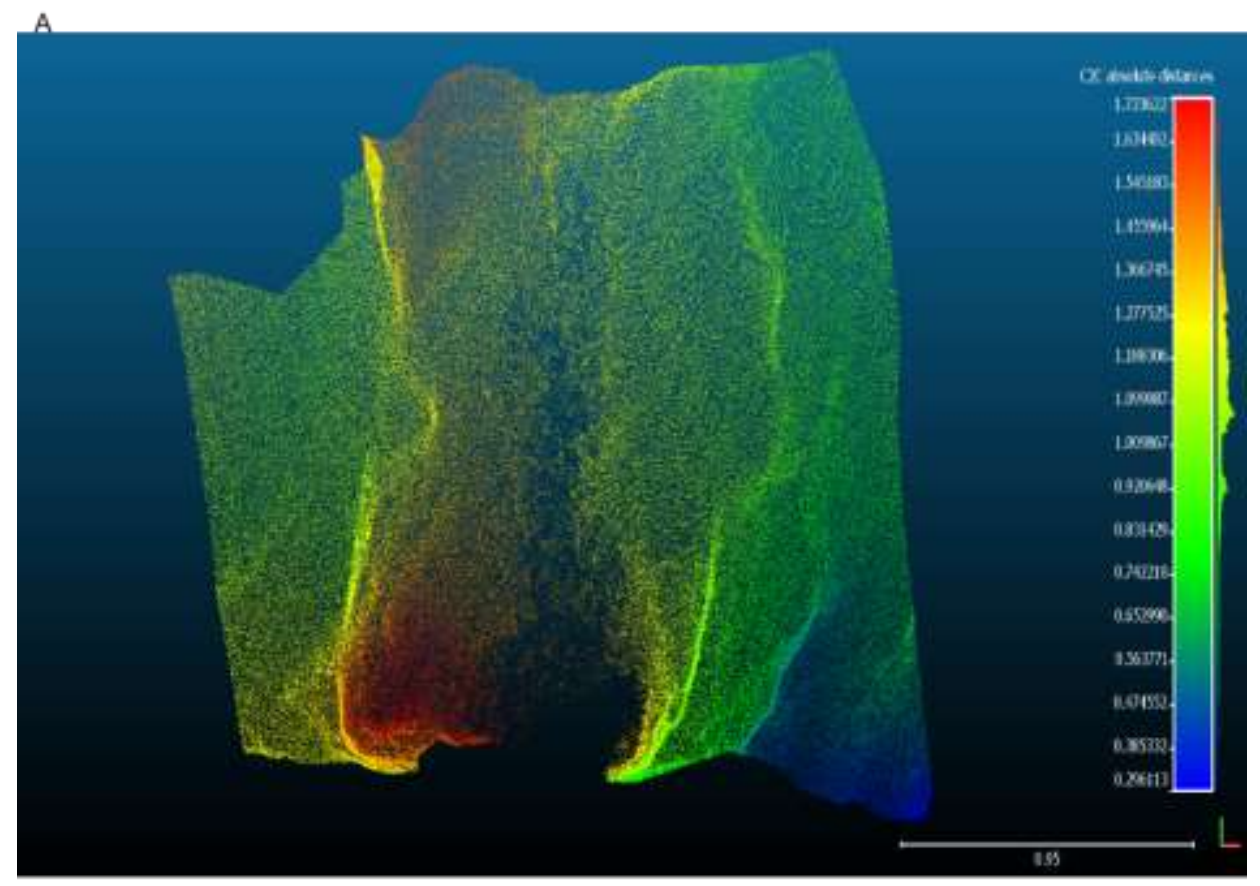

B

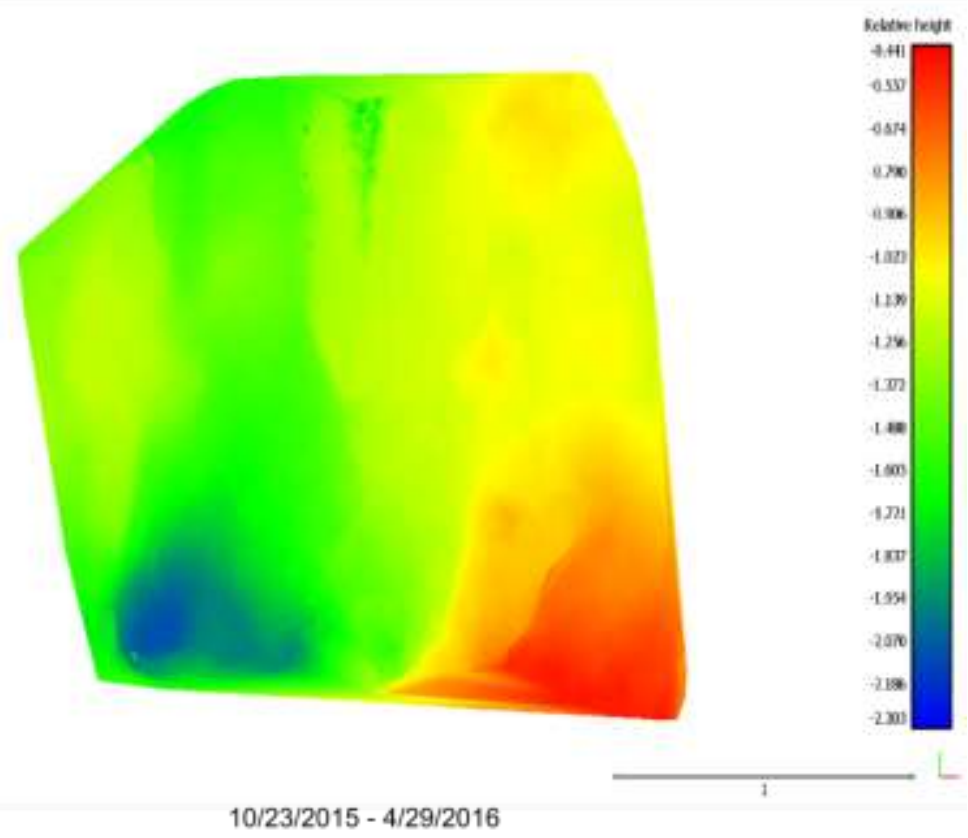

Figure 3.14: Panel A shows the pattern and distribution of minimum point to point distances between the knickpoint face on 10/23/2015 and 4/29/2016. Panel B shows a choropleth map of the change in horizontal distance of the knickpoint face 10/23/2015 and 4/29/2016. 
A significant geomorphological event was observed and recorded with TLS and photographs during this time interval, and was responsible for much of the $\sim 2 \mathrm{~m}$ of retreat on the left side of the knickpoint. A large tree near the knickpoint face collapsed into the plunge pool after extensive undercutting of the root ball at the side of the knickpoint lip. Figure 3.14c shows the knickpoint and tree (outlined with an arrow indicating failure direction) on 10/23/2015 before the collapse event. Figure 3.14d shows the undercutting of the root ball I observed on 11/11/2015. Figure $3.14 \mathrm{e}$ shows the root ball and tree after the collapse event, as well as how the upper channel and in turn the knickpoint lip had widened. The plunge pool and knickpoint base were initially inundated with loess and organic matter. The exact timing of this event is unknown but its impact on the geometry of the knickpoint face and behavior of erosion post collapse was captured as part of the point cloud data sets. 


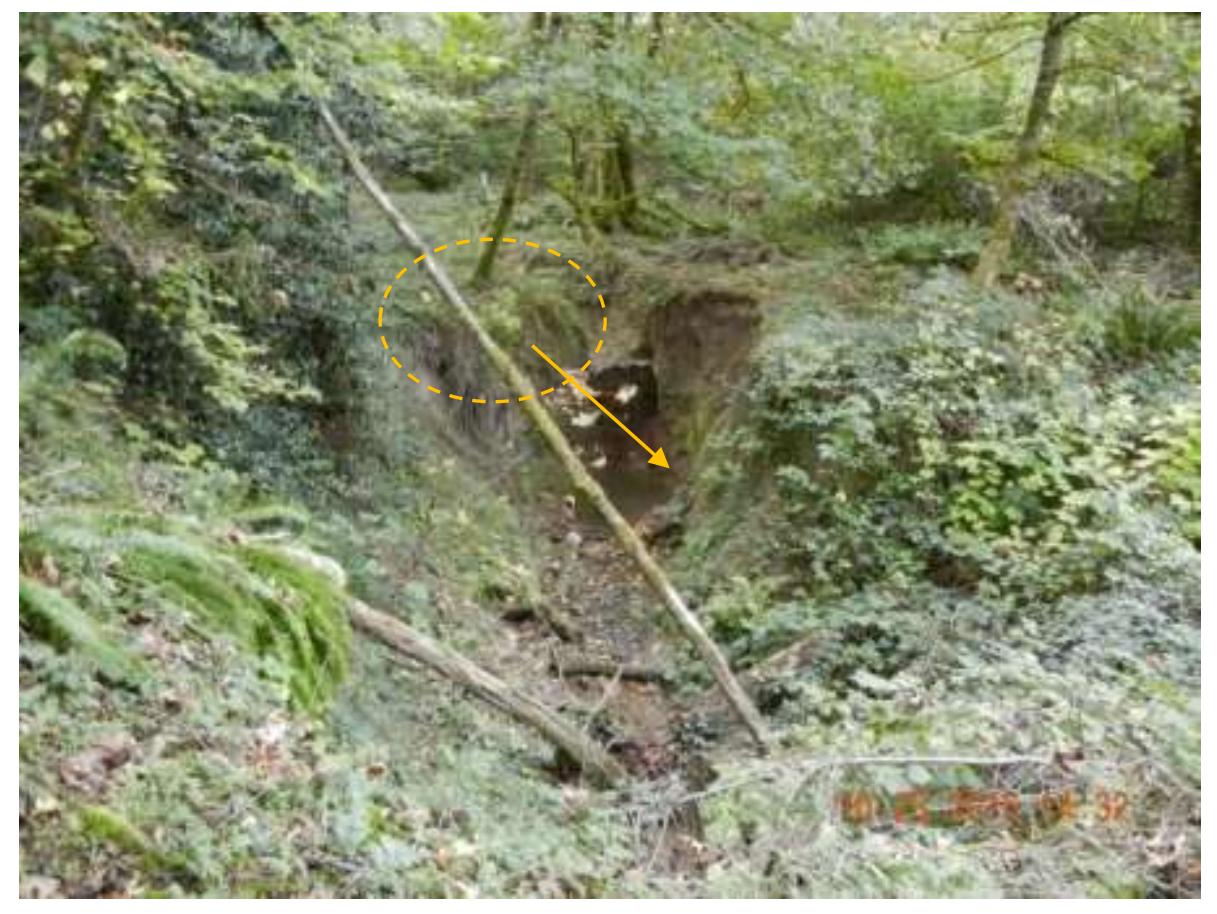

Figure 3.14c: The Morningstar knickpoint on 10/23/2015 before the rootball collapse. The root ball and the direction of failure is outlined in yellow. 


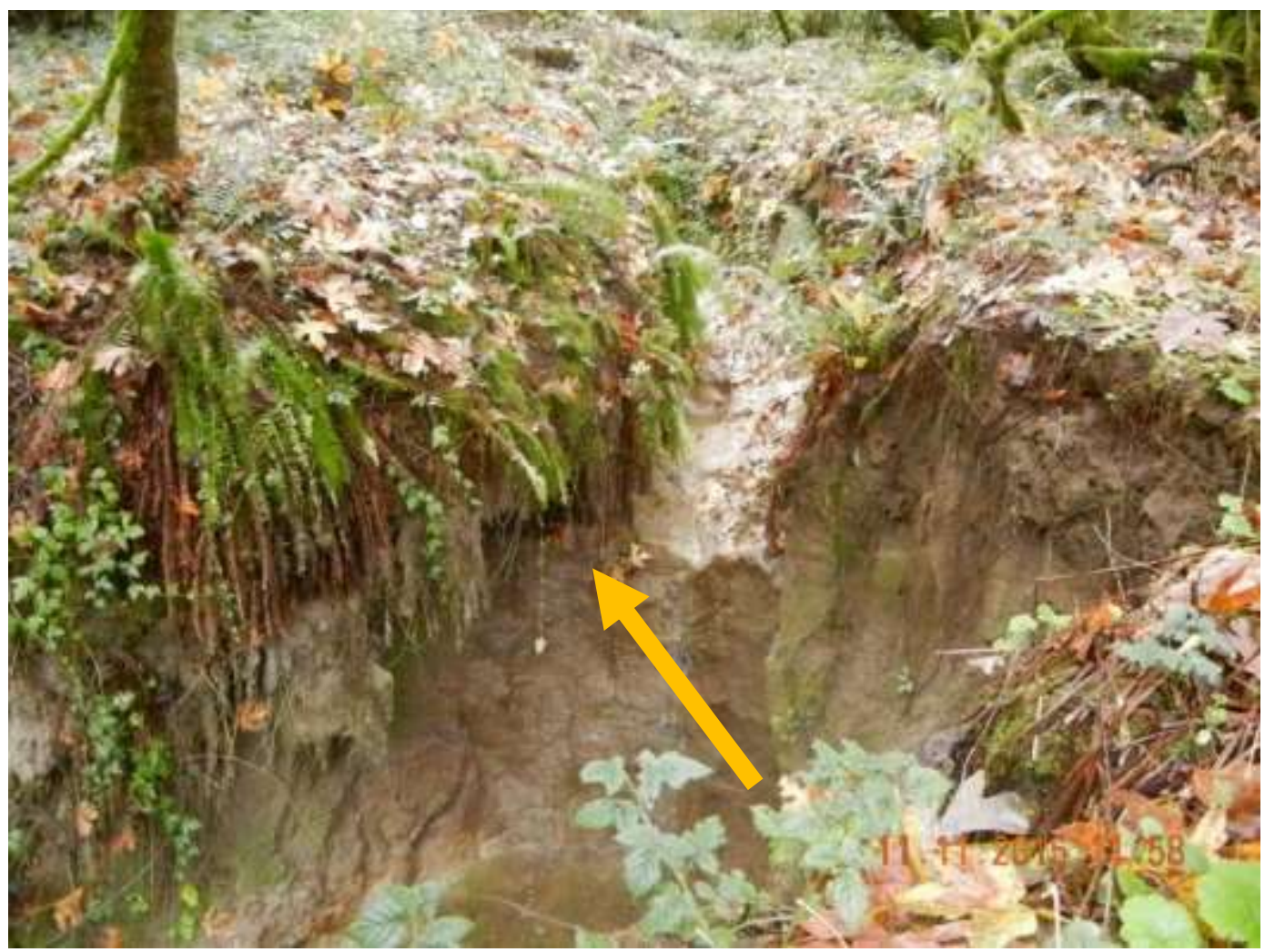

Figure 3.14d: The knickpoint face on 11/11/2015 with the root ball in the upper left portion of the photograph. The yellow arrow indicates areas of undercutting observed on this date. This undercutting is at the same elevation as the base of the upper channel. 


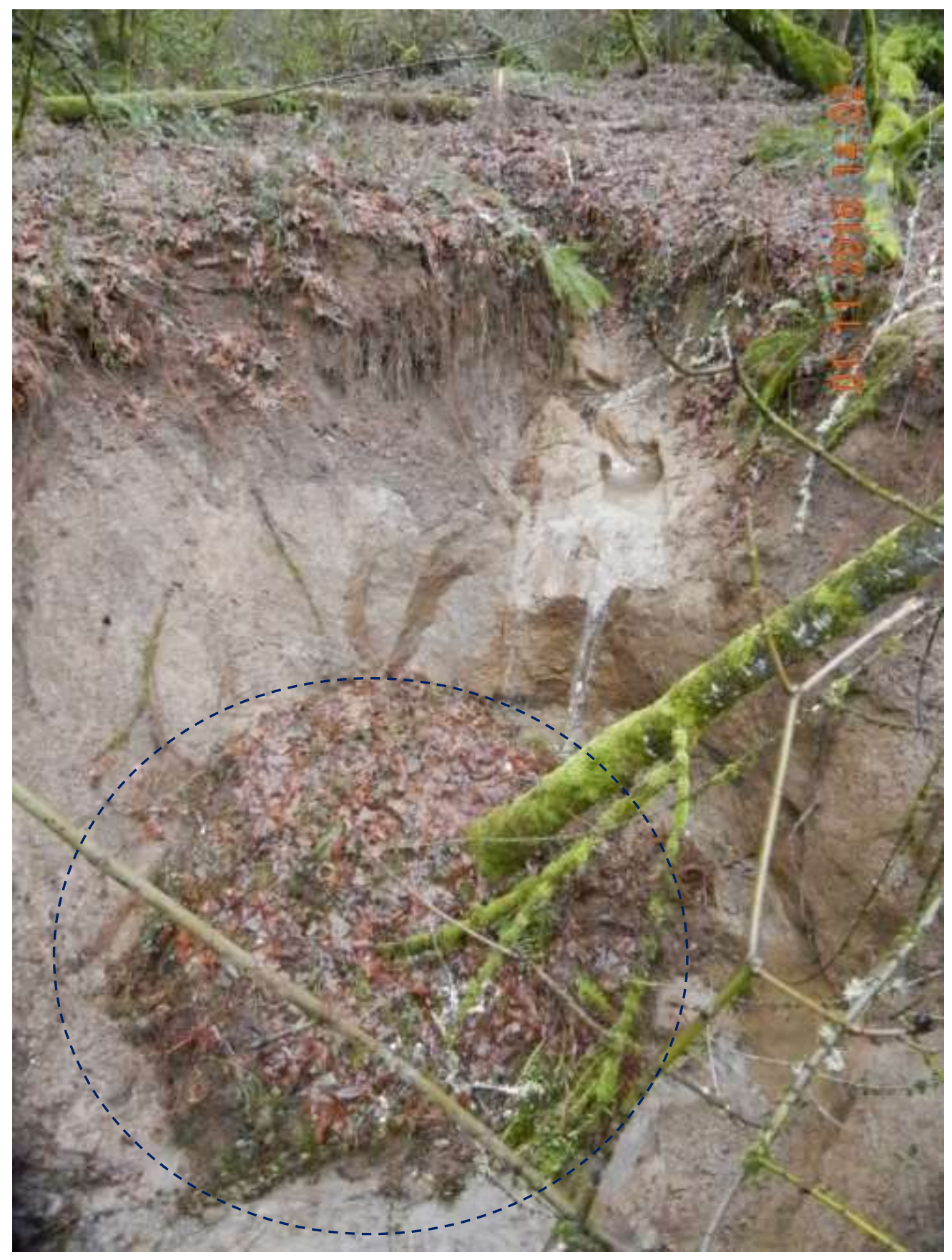

Figure 3.14e: The root ball (highlighted with a black dashed line) post collapse as it appeared on $1 / 20 / 2016$. 
For the third time period, the pattern of measured erosion between 4/29/2016 and 9/5/2016 based on point to point distance is shown in Figure 3.15a. The distribution of measured distances has a long tail extending to $0.50 \mathrm{~m}$, but the mode of the distribution is centered over $0.06 \mathrm{~m}$, which is greater than the MDD of $0.02 \mathrm{~m}$ for this time period. This small uniform difference (blue to green) in measured distance across most of the face is attributed to exfoliation. An area of probable block failure on the left side of $0.44 \mathrm{~m}$ is highlighted in red. The patterns of volumetric change per cell, shown in Figure 3.15b, more clearly show the variation in erosion and deposition across the knickpoint face. The face has an even coloring of green, corresponding to a change in upstream distance centered on $0.14 \mathrm{~m}$. On the left side of the face a larger section of relative change, peaking at $0.66 \mathrm{~m}$, is shown in blue. At the base near the center of the face a small area of undercutting resulted in another relatively high amount $(\sim 0.59 \mathrm{~m})$ of eroded material. Total volume of erosion was $-0.65 \mathrm{~m}^{3}$ across the $3.73 \mathrm{~m}^{2}$ surface area of the face (Table 3.1). The amount of upstream retreat for this period was $-0.174 \mathrm{~m}$ as shown in Table 3.1. 

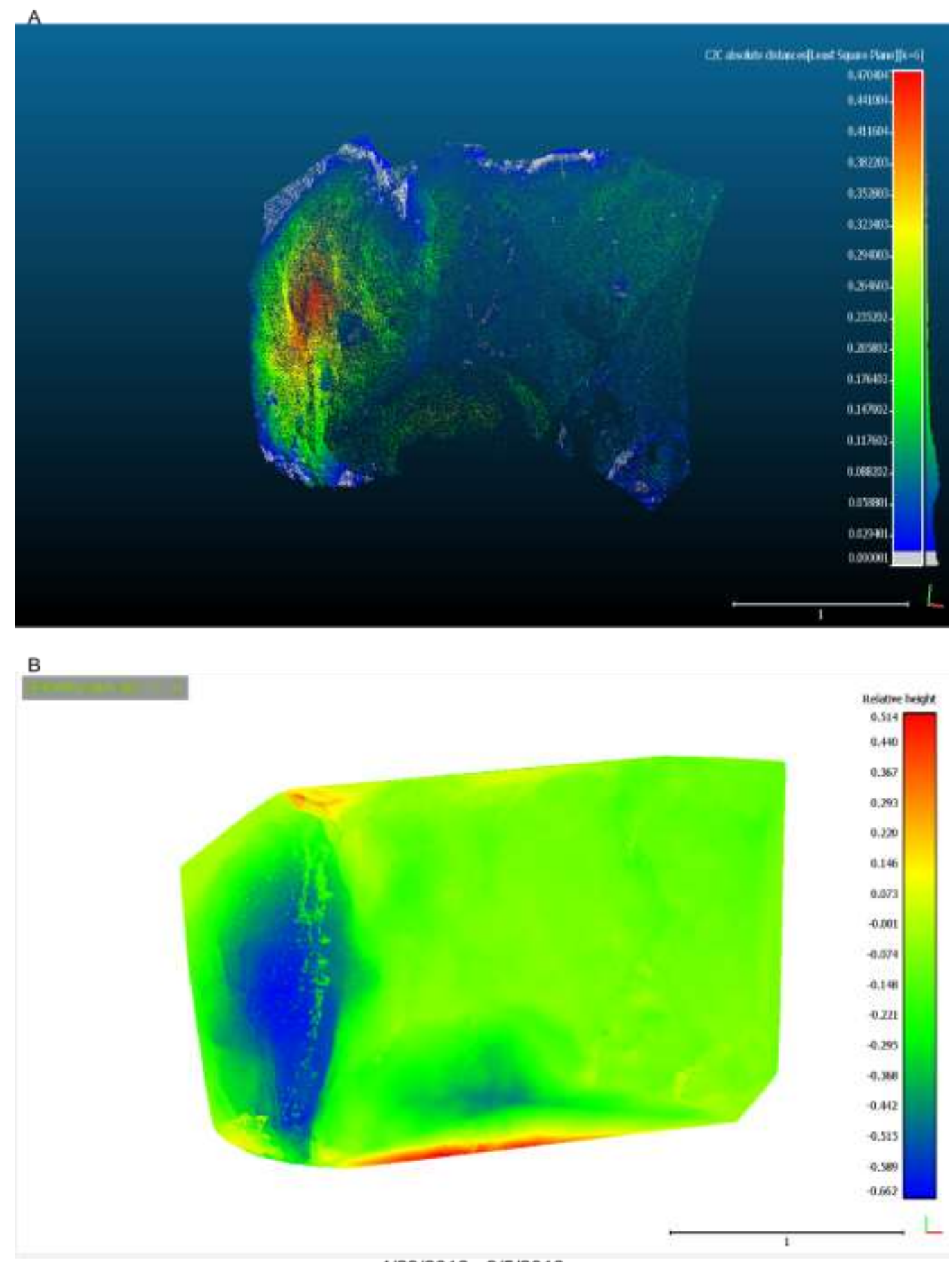

$4 / 29 / 2016$ - 9/5/2016

Figure 3.15: Panel A shows the pattern and distribution of minimum point to point distances between the knickpoint face on 4/29/2016 and 9/5/2016. Panel B shows a choropleth map of the change in horizontal distance of the knickpoint face between 4/29/2016 and 9/5/2016. 
For the fourth and final time period documented with point clouds, the visual pattern of erosion based on point to point distance between 9/5/2016 and 11/18/2016 is shown in Figure 3.16a. The right side of the knickpoint, areas of blue, include differences in measured distance between $0.045 \mathrm{~m}$ and $0.09 \mathrm{~m}$, greater than the MDD of $0.01 \mathrm{~m}$. This is attributed to exfoliation. On the left side of the face areas in red to orange correspond to a measured retreat distance of $0.593 \mathrm{~m}$ to $0.73 \mathrm{~m}$. This is attributed to block failure. The pattern of volumetric change per cell is shown in Figure 3.16b. It reveals that the areas where the largest volume of material was eroded were located at the top of the undercut cave. The upper rim of the plunge pool cave, blue, experienced a loss of $1.02 \mathrm{~m}$ while rest of the face underwent $0.683 \mathrm{~m}$ or less of erosion. Total volume of erosion was $-1.55 \mathrm{~m}^{3}$ across the $3.69 \mathrm{~m}^{2}$ surface area of the face (Table 3.1). The amount of upstream retreat for this period was $-0.42 \mathrm{~m}$ as shown in Table 3.1 . 


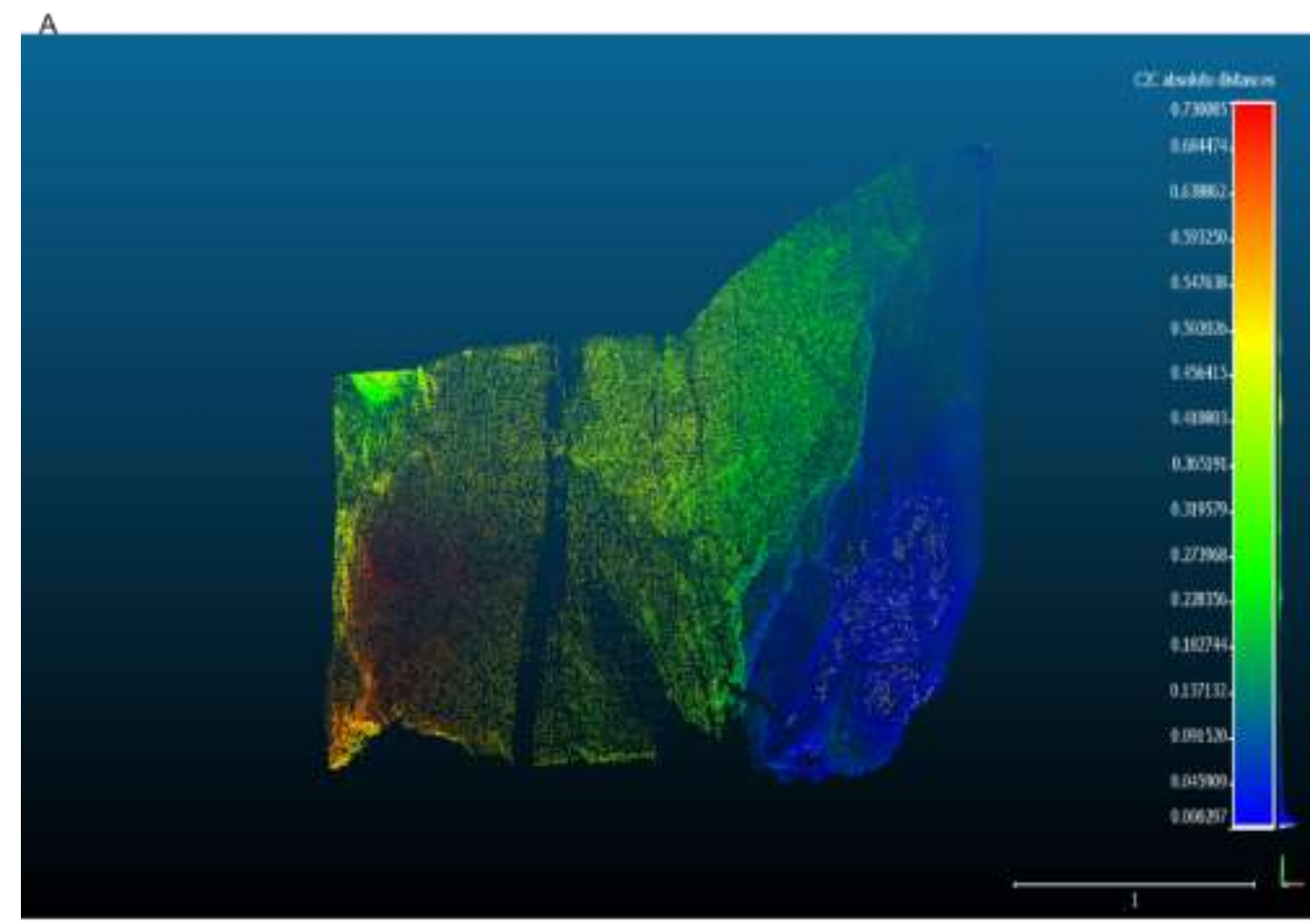

B

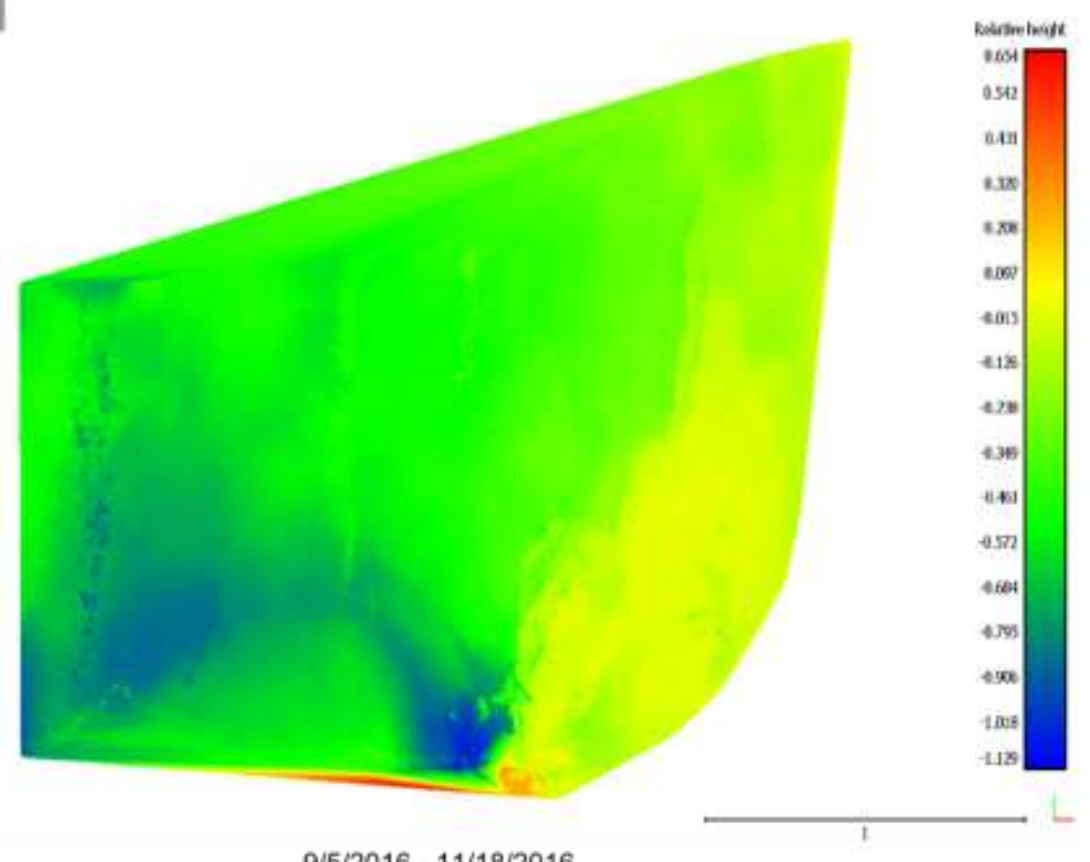

$9 / 5 / 2016-11 / 18 / 2016$

Figure 3.16: Panel A shows the pattern and distribution of minimum point to point distances between the knickpoint face on 9/5/2016 and 11/18/2016. Panel B shows a choropleth map of the change in horizontal distance of the knickpoint face between 9/5/2016 and 11/18/2016. 
The fifth and final interval pair is unique in that it is not the result of point cloud analysis because changes were too large to document with that technique. The changes between 11/18/2016 and 4/9/2017 can best be seen in a comparison of photographs and field observations. The knickpoint face on 4/9/2017 appears to have the same general form, height, width, and undercutting when compared to 11/18/2016 observation. The measured upstream retreat was $-12.5 \mathrm{~m}$. Figure 3.17 shows where the knickpoint face was and where it retreated. A panoramic image (Fig. 3.18) highlights the path of retreat and the approximate locations of knickpoint face as recorded during previous observation (as well as observed intact sediment macro structures suspected to be portions of the past knickpoint face). A clear indication of primary modes of erosion cannot graphically be seen as the previous TLS interval pairs, but Figure 3.19a shows indication of exfoliation. Figure $3.19 \mathrm{~b}$ shows results of block failures with many cobble sized chunks of sediment in the lower channel along the path of retreat. 


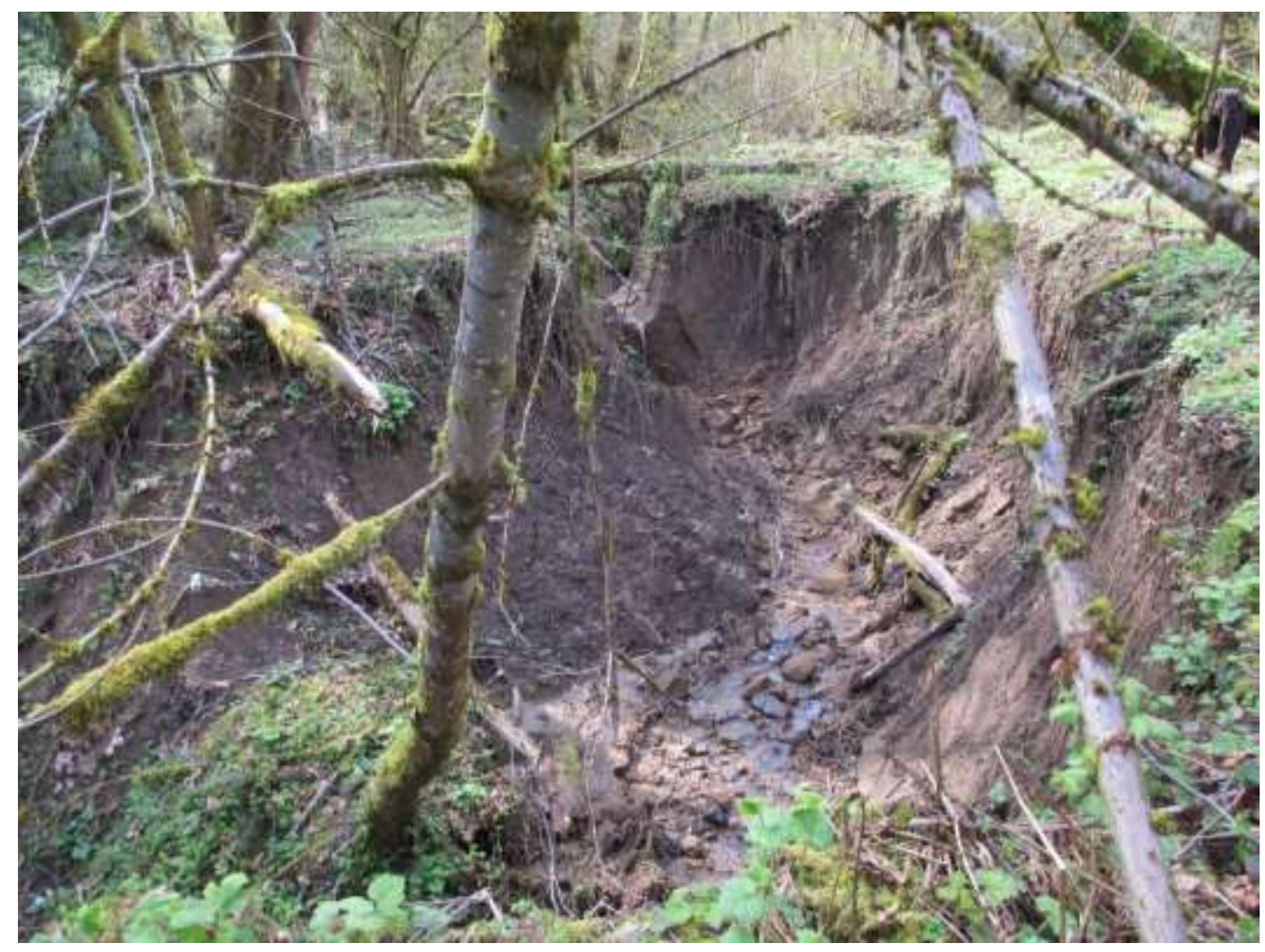

Figure 3.17: The lower channel and knickpoint face (background) on 4/9/2017. The root ball collapse (foreground) is the approximate location of the knickpoint on $11 / 18 / 2016$. 


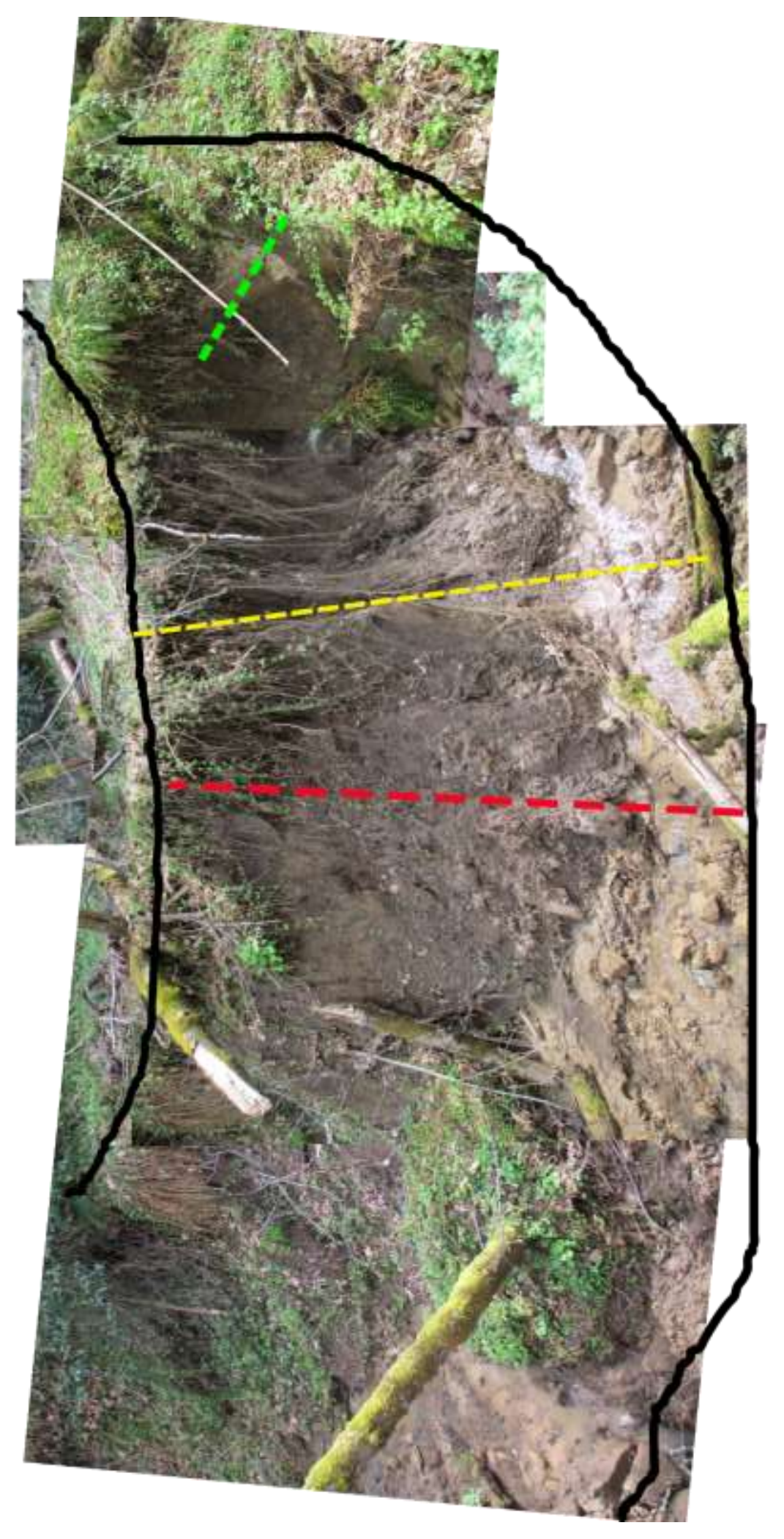

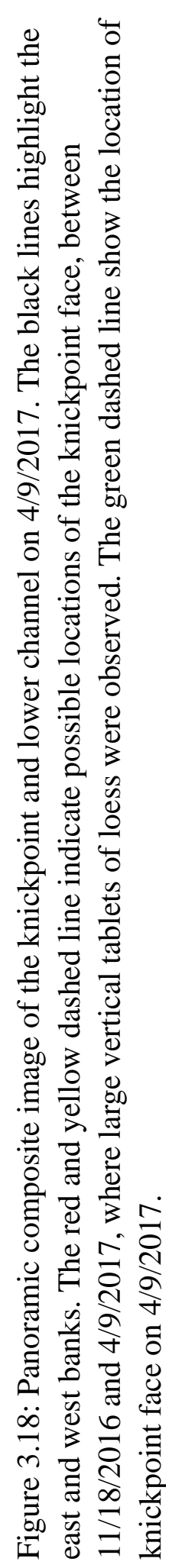




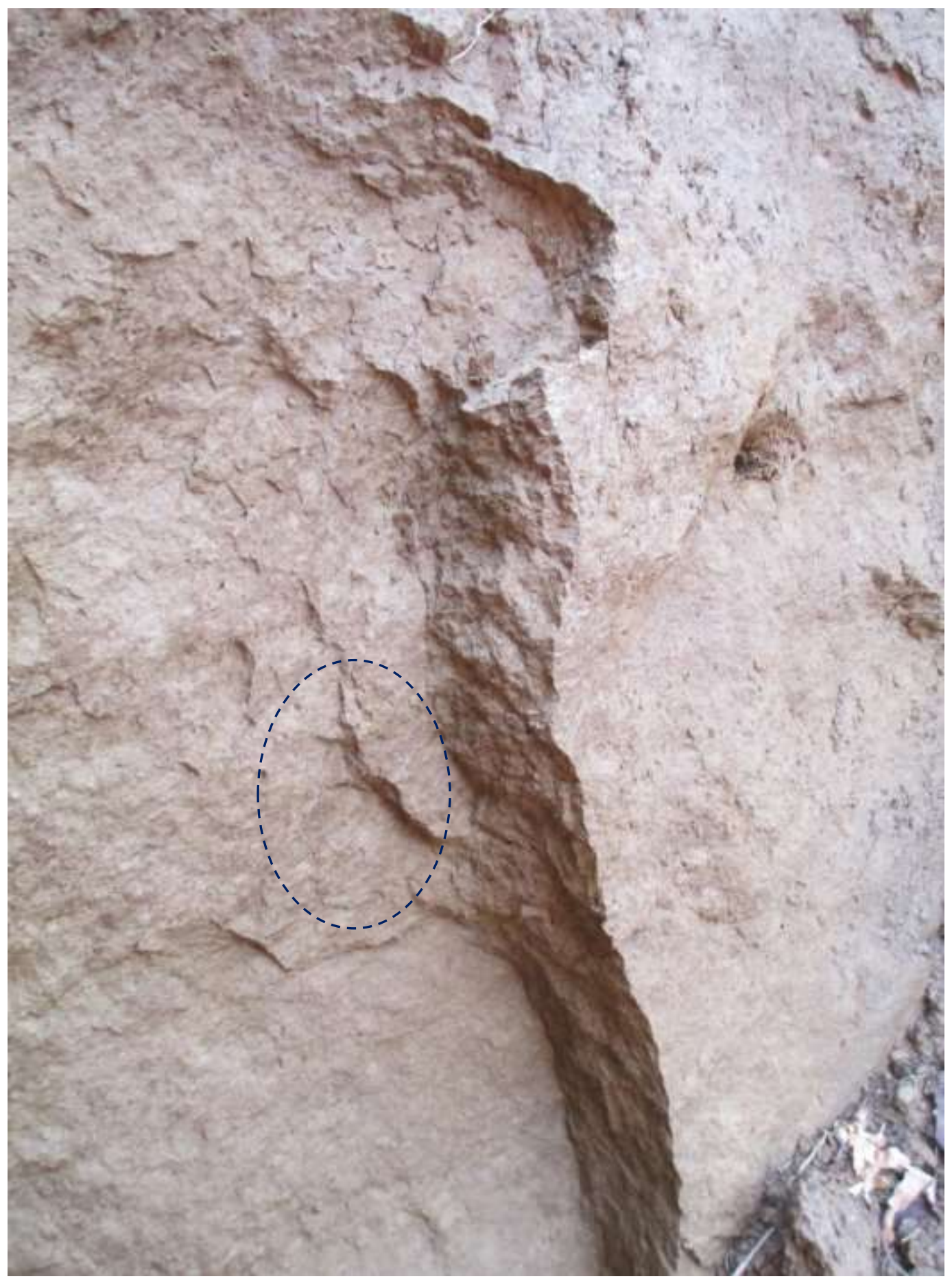

Figure 3.19a: Example of sheet failure margins (blue dashed circle), defined as exfoliation in this study, observed on 4/9/2017. These are adjacent to the margin of a much larger block failure. 


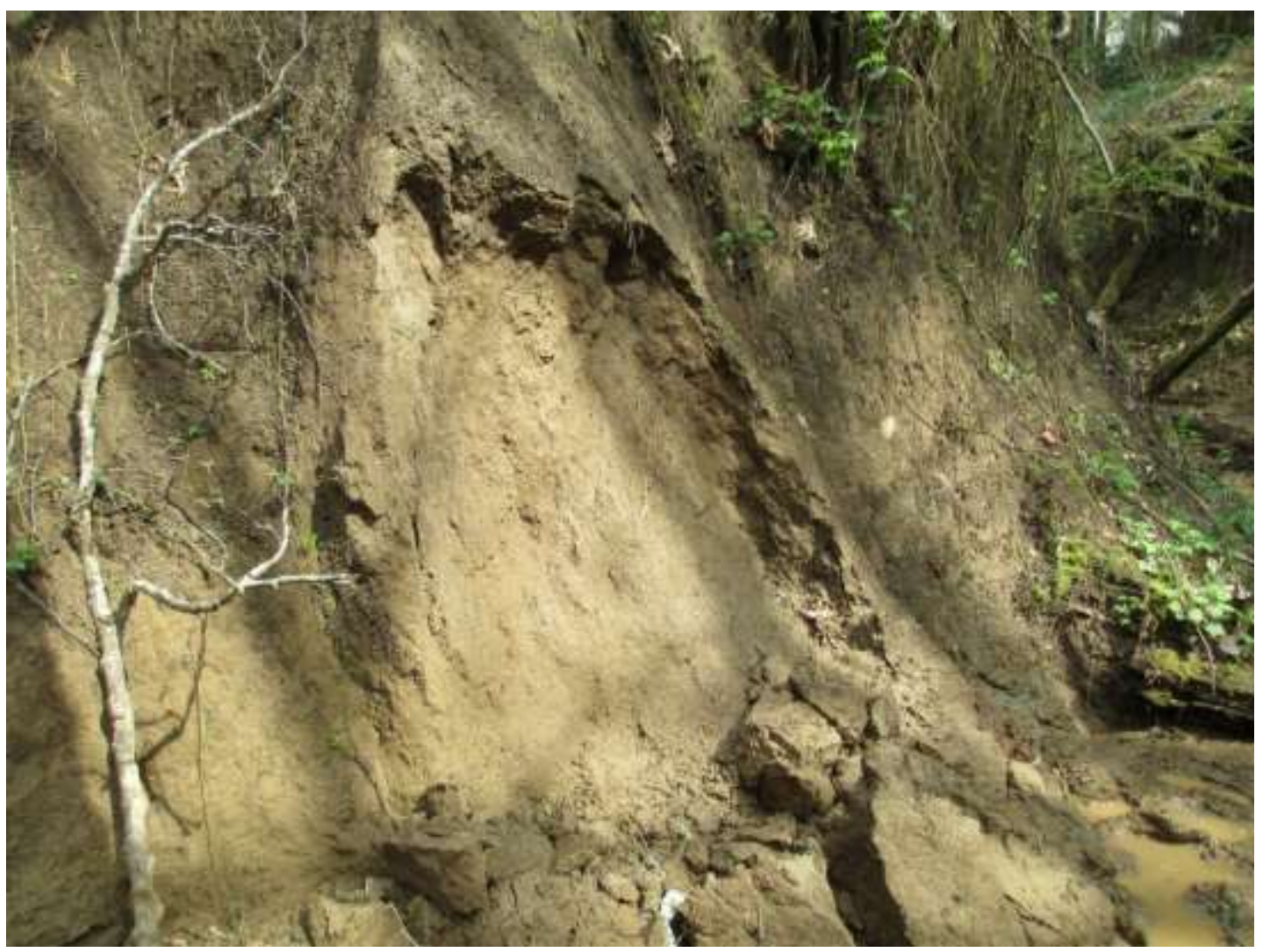

Figure 3.19b: Typical large block failure observed on 4/9/2017. Large clumps of loess in a pile in near the bed of the lower channel as a result of block calving off the banks.

In addition to the five previously discussed interval pairs that are presented in chronological order, combinations of data sets into interval pairs over longer time periods were analyzed. These interval pairs allowed me to examine longer term erosion patterns and increased the sample size for comparison to hydrologic metrics (as discussed in the next section). In Appendix B, I continue to describe the patterns and amount of erosion for the interval pairs: $8 / 19 / 2015$ to $4 / 29 / 2016,4 / 29 / 2016$ to $11 / 18 / 2016,8 / 19 / 2015$ to $9 / 5 / 2016,10 / 23 / 2015$ to $9 / 5 / 2016,10 / 23 / 2015$ to $11 / 18 / 2016$, and the final, longest interval of $8 / 19 / 2015$ to $11 / 18 / 2016$. 
Table 3.1 shows the volume lost and the area of the knickpoint face for each interval pair discussed above. These values with the amount of time between each interval pair were used to calculate the retreat rates reported in Table 3.1. The retreat rates excluding the extreme event have a range between -0.23 and $-2.45 \mathrm{~m} / \mathrm{yr}$ with an average of $-1.52 \mathrm{~m} / \mathrm{yr}$. Including the extreme erosion event results in a range between -0.23 and $-32.13 \mathrm{~m} / \mathrm{yr}$ with an average of $-4.31 \mathrm{~m} / \mathrm{yr}$. Note that the average is highly biased by the largest retreat rate, and that, for most of the study, the rates were much lower.

\subsubsection{Hydrologic Controls on Volumes Erosion and Retreat Rates}

The images described above provide insight on spatial patterns and behavior of erosion. The quantitative record of volume changes due to erosion and retreat rates provides further clues on the underlying physical processes driving and related to the channelized erosion.

Included in Table 3.2 are four metrics of precipitation for the study period. For each interval pair the cumulative amount of precipitation in meters that occurred during that time interval, the number of wetting and drying cycles, the precipitation rate averaged over the interval, and the percentage of days during the interval $\geq 0.015 \mathrm{~m}$ of precipitation occurred, was calculated. The threshold value for the fourth metric was optimized for correlation through plotting a range of different daily precipitation values and finding the threshold that produced the highest $\mathrm{R}^{2}$ value. Each of these metrics was regressed against knickpoint migration rates in two sets, one including and one excluding 
the extreme erosion data point. Additionally the regression information for a subplot of the wetting and drying cycle consisting of three data points is included in Table 3.1. This was done to help reveal the association between the observed exfoliation mechanism of erosion at the knickpoint, the retreat rates, and the precipitation metrics. The cumulative precipitation between each interval pair approximates the total amount of water that flowed across the knickpoint, resulting in the cumulative erosion for that time interval, which incorporates the combined effects of the three other metrics.

Figure 3.20a shows the relationship between the retreat rates and total precipitation for all point cloud recorded interval pairs. The total precipitation for the point cloud intervals and the extreme erosion interval is plotted in Figure 3.20b. Both plots, and all the following plots in this section, include a linear regression line and the $95 \%$ confidence interval on the slope of the fit. The set containing point cloud interval pair data only is regressed by a line with equation $y=0.750+0.835 x$, where $y$ is retreat rate in $\mathrm{m} / \mathrm{yr}$ and $\mathrm{x}$ is cumulative precipitation in $\mathrm{m}$ (Table 3.2). This fit has a coefficient of determination $\left(\mathrm{R}^{2}\right)$ of 0.51 . Despite the relatively low $\mathrm{R}^{2}$ indicating that the data are scattered, there is $97.96 \%$ confidence that the regression slope is significantly different from zero, an indication that the erosion rate is positively correlated with cumulative precipitation. As the amount of precipitation between intervals increases there is an increase in the rate of retreat. Table 3.5 shows the point cloud interval data plus the extreme erosion data point, and is fitted with a line, $y=4.299+0.010 x$, where $y$ is retreat rate in $\mathrm{m} / \mathrm{yr}$ and $\mathrm{x}$ is cumulative precipitation in $\mathrm{m}$. This regression has an $\mathrm{R}^{2}$ of 0 and a $0.1 \%$ confidence that the slope of the line is significantly different from zero. 

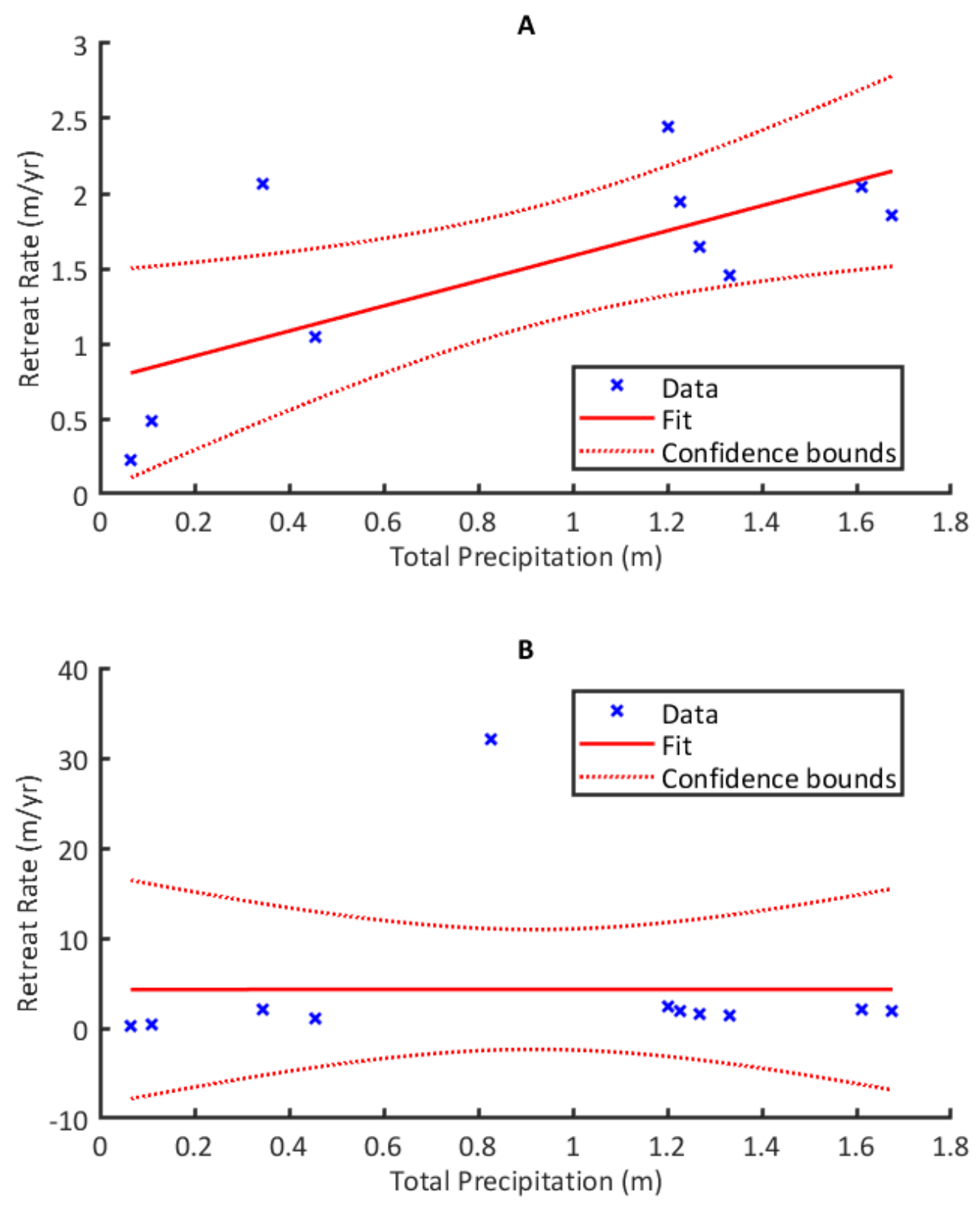

Figure 3.20: (A) Shows retreat rate in $\mathrm{m} / \mathrm{yr}$ as a function of total precipitation in meters between point cloud based interval pairs. (B) Shows total precipitation plotted against retreat rates from the point cloud based interval pairs and the extreme erosion event. The dashed red lines show the boundary of the $95 \%$ confidence on the slope of the data points. The solid red line is a linear regression trend. 
Table 3.2: Analysis of fit and confidence of linear regression of retreat rate and four precipitation metrics, including point cloud interval pair data only and point cloud interval data plus extreme event. Statistically significant linear trends at the 95\% confidence level are shown in bold. For all linear regression equation, $\mathrm{y}$ is retreat rate in $\mathrm{m} / \mathrm{yr}$ and $\mathrm{x}$ is the precipitation metric of interest.

\begin{tabular}{|c|c|c|}
\hline Precipitation Metric & $\begin{array}{l}\text { Point cloud interval } \\
\text { pair Data }\end{array}$ & $\begin{array}{c}\text { Point cloud interval } \\
\text { data plus extreme } \\
\text { event }\end{array}$ \\
\hline \multirow[t]{3}{*}{ Total Precipitation (m) } & $y=0.750+.835 x$ & $\mathrm{y}=4.299+0.010 \mathrm{x}$ \\
\hline & $\mathbf{R}^{2}=\mathbf{0 . 5 1}$ & $\mathrm{R}^{2}=0$ \\
\hline & $\begin{array}{c}\% \text { confidence of } \\
\text { slope }=97.96\end{array}$ & $\begin{array}{l}\% \text { confidence of } \\
\text { slope }=0.10\end{array}$ \\
\hline \multirow[t]{3}{*}{ Wet/Dry Cycles } & $\mathrm{y}=0.895+0.234 x$ & $y=6.7+-0.091 x$ \\
\hline & $\mathrm{R}^{2}=0.246$ & $\mathrm{R}^{2}=0.0214$ \\
\hline & $\begin{array}{c}\% \text { confidence of } \\
\text { slope }=85.5\end{array}$ & $\begin{array}{l}\% \text { confidence of } \\
\text { slope }=43.2 \\
\end{array}$ \\
\hline $\begin{array}{l}\text { Wet/Dry Cycles for } \\
\text { three exfoliation based } \\
\text { retreat rates }\end{array}$ & $y=-0.13+0.055 x$ & \\
\hline \multirow[t]{2}{*}{ (see Fig. 3.31) } & $R^{2}=0.99$ & \\
\hline & $\begin{array}{c}\% \text { confidence of } \\
\text { slope }=94.1\end{array}$ & \\
\hline \multirow[t]{3}{*}{$\begin{array}{l}\text { Average Precipitation Rate } \\
(\mathrm{m} / \mathrm{yr})\end{array}$} & $y=0.099+1.11 x$ & $y=-4.15+6.24 x$ \\
\hline & $\mathbf{R}^{2}=\mathbf{0 . 9 3 4}$ & $\mathrm{R}^{2}=0.188$ \\
\hline & $\begin{array}{c}\% \text { confidence of } \\
\text { slope }=99.9\end{array}$ & $\begin{array}{l}\% \text { confidence of } \\
\text { slope }=81.7\end{array}$ \\
\hline \multirow[t]{3}{*}{$\begin{array}{c}\% \text { of day when over } 0.015 \mathrm{~m} \\
\text { of precipitation occurred }\end{array}$} & $y=0.355+0.1942 x$ & $y=-4.023+1.27 x$ \\
\hline & $\mathbf{R}^{2}=0.928$ & $\mathrm{R}^{2}=0.278$ \\
\hline & $\begin{array}{l}\% \text { confidence of } \\
\text { slope }=99.9\end{array}$ & $\begin{array}{l}\% \text { confidence of } \\
\text { slope }=90.5\end{array}$ \\
\hline
\end{tabular}


Figure 3.21a shows the relationship between the retreat rates and number of wetting and drying cycles for point cloud recorded interval pairs only. The number of cycles and corresponding retreat rates for the point cloud intervals and the extreme erosion interval is plotted in Figure 3.21b. The set containing point cloud interval pair data is regressed by a line with the equation $y=0.895+0.234 x$, where $y$ is retreat rate in $\mathrm{m} / \mathrm{yr}$ and $\mathrm{x}$ is the number of wet/dry cycles (Table 3.2). This fit has a coefficient of determination $\left(\mathrm{R}^{2}\right)$ of 0.246 . There is $85.5 \%$ confidence that the regression slope is significantly different from zero, so the null hypothesis that retreat rate does not depend on the number of wet/dry cycles cannot be rejected. Table 3.2 shows that the point cloud interval data plus the extreme erosion data point was fitted with a line, $y=6.7+-0.091 x$, where $\mathrm{y}$ is retreat rate in $\mathrm{m} / \mathrm{yr}$ and $\mathrm{x}$ is the number of wet/dry cycles. This regression has an $\mathrm{R}^{2}$ of 0.214 and a $43.2 \%$ confidence that the slope of the line is significantly different than zero. Neither of these data sets reveal a significant linear correlation between wetting and drying cycle and retreat rate. Therefore, a subset of the data, over intervals where exfoliation was observed to be the dominant mechanism of erosion, was selected and plotted separately. 
A

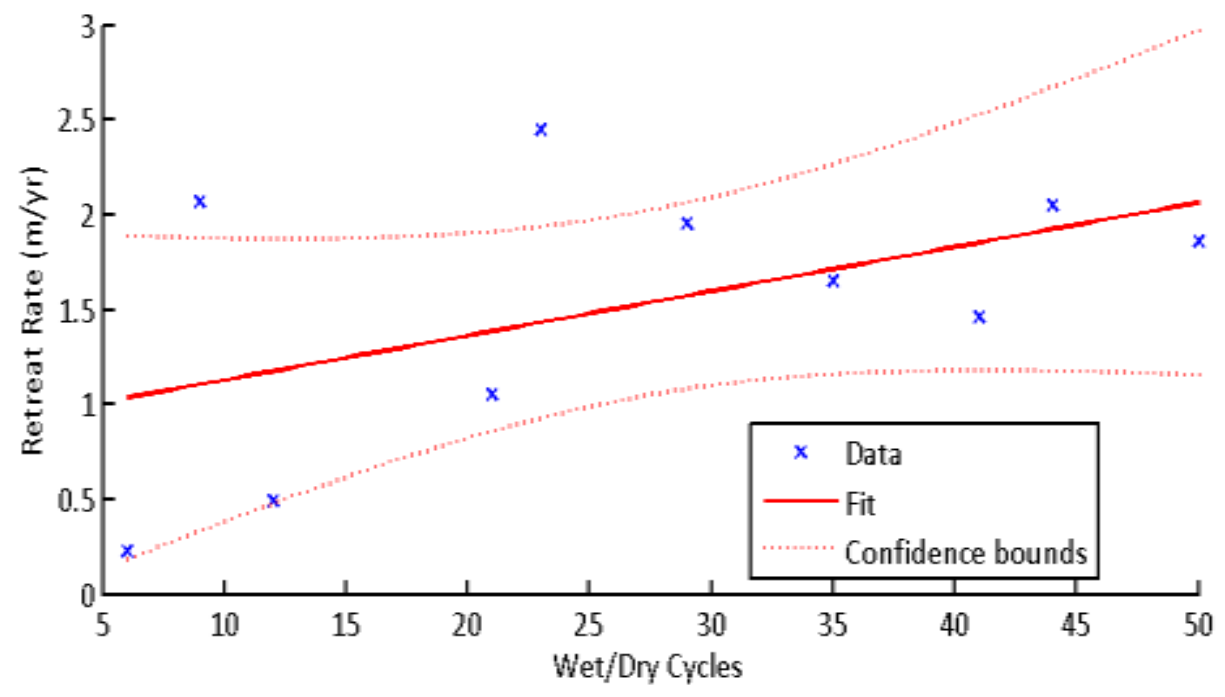

B

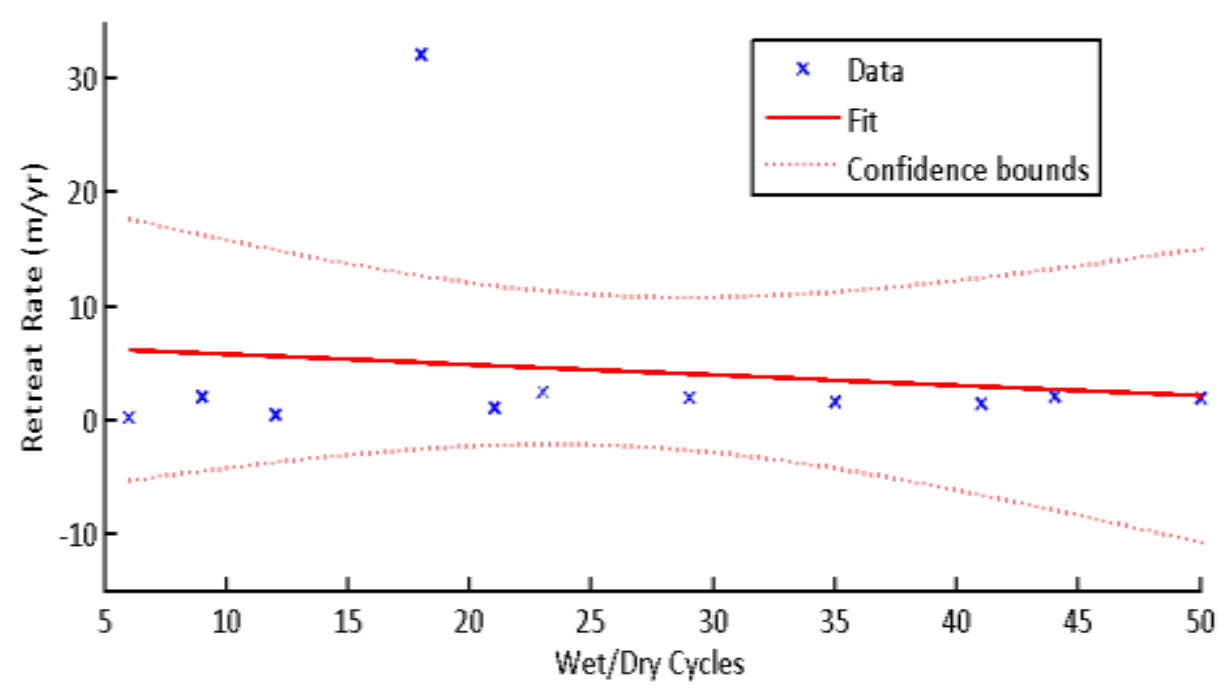

Figure 3.21: (A) Shows the number of wetting and drying cycles plotted against the retreat rates between point cloud based interval pairs. (B) Shows the number of wetting and drying cycles plotted against the retreat rate from point cloud based interval pairs and the extreme erosion event. The dashed red lines show the boundary of the $95 \%$ confidence on the slope of the data points. The solid red line is a linear regression trend. 
Figure 3.22 highlights the relationship between wetting and drying cycles and retreat rate for the three interval pairs in which significant exfoliation based erosion was observed. The interval pairs included in Figure 3.22 are 8/19/2015 - 10/23/2015, 4/29/2016 - 9/5/2016, and 4/29/2016 - 11/18/2016. During these interval pairs, below average total precipitation and below average precipitation rate was observed. The red line shows the linear trend from regression of these data points. The equation for the fit line is $\mathrm{y}=-0.13+0.055 \mathrm{x}$, where $\mathrm{y}$ is retreat rate and $\mathrm{x}$ is number of wetting/drying cycles. This equation has a coefficient of determination $\left(\mathrm{R}^{2}\right)$ of 0.99 . There is a $94.1 \%$ confidence that the slope of the line is significantly different than zero (Fig. 3.22). Although the fit explains $99 \%$ of the variance, it does not quite meet the $95 \%$ confidence threshold, so the null hypothesis cannot formally be rejected. Nonetheless, the confidence is much higher than when all data point were considered. 


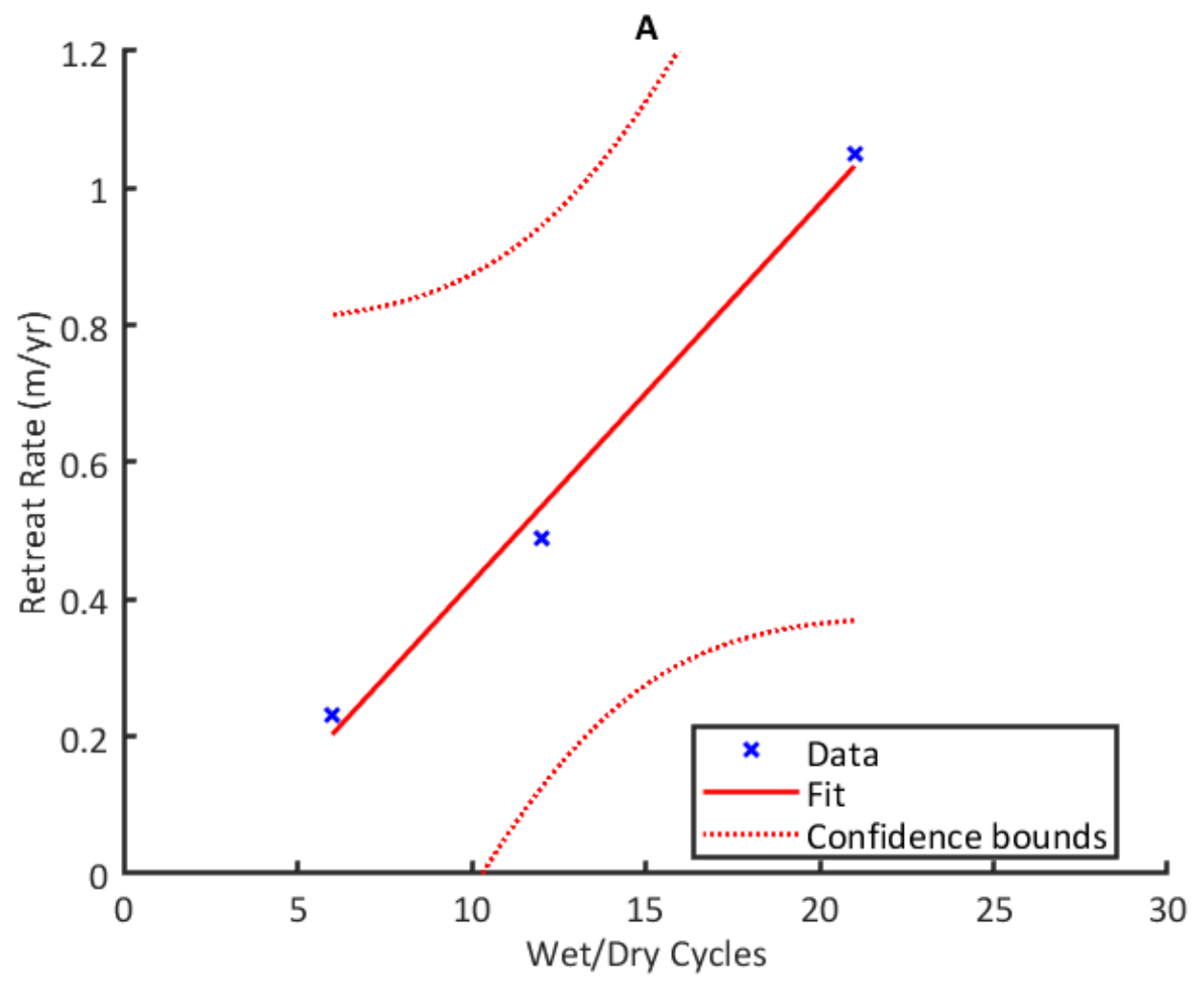

Figure 3.22: The three interval pair average retreat rate data points where sheet exfoliation was observed to be the dominant mode of erosion are plotted against the correlative number of precipitation wetting/drying cycles. The red dashed lines show the confidence interval on the slope of the regression. The solid red line is a linear regression trend. 
Figure 3.23a shows the relationship between the retreat rates and average precipitation for all point cloud recorded interval pairs. The average precipitation for the point cloud intervals and the extreme erosion interval is plotted in Figure 3.23b. The set containing point cloud interval pair data is regressed by a line with the equation $\mathrm{y}=0.099+1.11 \mathrm{x}$, where $\mathrm{y}$ is retreat rate in $\mathrm{m} / \mathrm{yr}$ and $\mathrm{x}$ is average precipitation in $\mathrm{m} / \mathrm{yr}$ (Table 3.2). This fit has a coefficient of determination $\left(\mathrm{R}^{2}\right)$ of 0.934 . This very high $\mathrm{R}^{2}$, indicates that the data are not scattered, and leads to $99.9 \%$ confidence that the regression slope is significantly different from zero. This is an indication that the erosion rate is positively correlated with average precipitation rate. As the average precipitation rate between intervals increases there is in an increase in the rate of retreat. Table 3.2 shows that the point cloud interval data plus the extreme erosion data point was fitted with a line, $\mathrm{y}=-4.15+6.24 \mathrm{x}$ where $\mathrm{y}$ is retreat rate in $\mathrm{m} / \mathrm{yr}$ and $\mathrm{x}$ is average precipitation rate in $\mathrm{m} / \mathrm{yr}$. This regression has an $\mathrm{R}^{2}$ of 0.188 and $81.7 \%$ confidence that the slope of the line is significantly different than zero. 
A

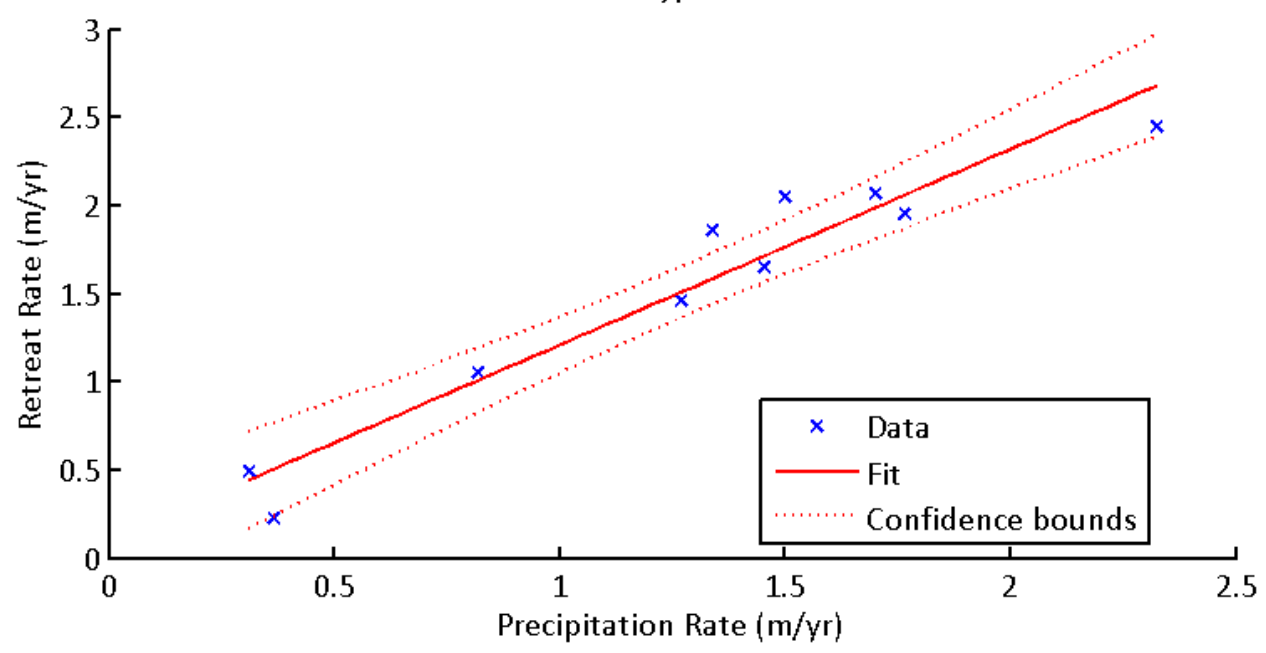

B

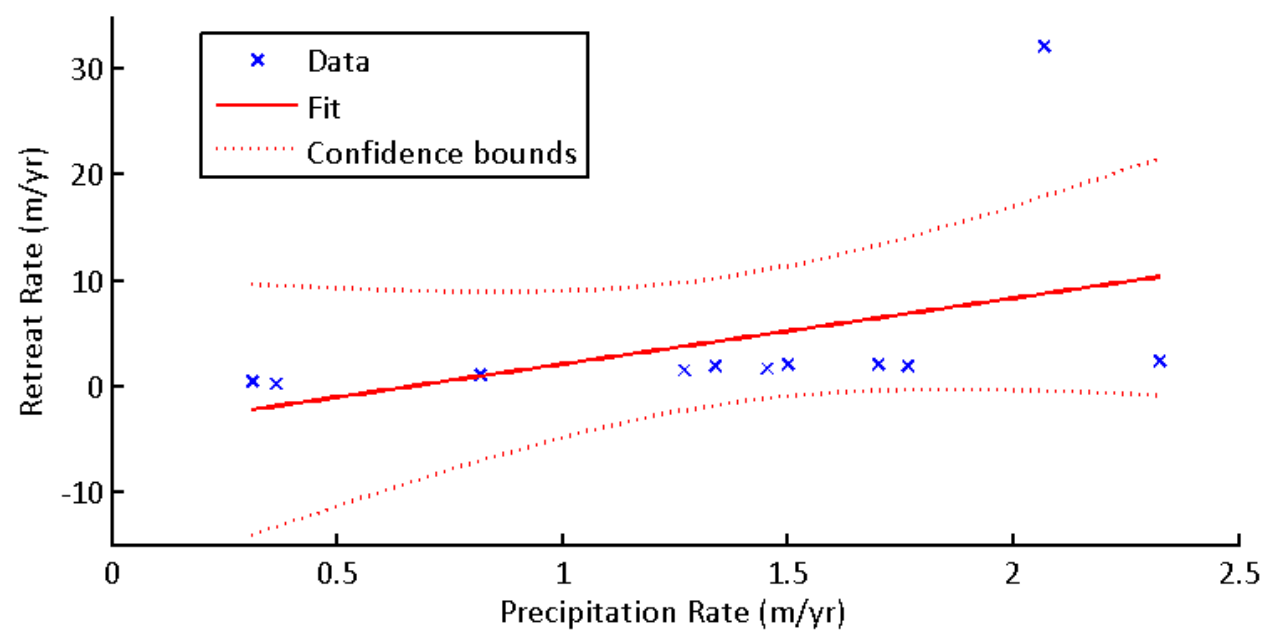

Figure 3.23: (A) Shows the average rate of precipitation shown plotted against the average retreat rate for point cloud interval pairs. The plot (B) includes the data point from the interval pair of 11/18/2016 and 4/9/2017. The retreat rate increases gradually with average precipitation rates below $2 \mathrm{~m} / \mathrm{yr}$. The retreat rate become highly variable in response to precipitation rates greater than $2 \mathrm{~m} / \mathrm{yr}$. The dashed red lines show the boundary of the $95 \%$ confidence on the slope of the data points. The solid red line is a linear regression trend. 
Figure 3.24a shows the relationship between the retreat rates and the percentage of days when $\geq 0.015 \mathrm{~m}$ of precipitation occurred for all point cloud recorded interval pairs. The percentage of days when $\geq 0.015 \mathrm{~m}$ of precipitation occurred for the point cloud intervals and the extreme erosion interval is plotted in Figure 3.24b. The set containing point cloud interval pair data is regressed by a line with the equation $\mathrm{y}=0.355+0.1942 \mathrm{x}$, where $\mathrm{y}$ is retreat rate in $\mathrm{m} / \mathrm{yr}$ and $\mathrm{x}$ is the percentage of day in which over $0.015 \mathrm{~m}$ of precipitation occurred (Fig. 3.24a and Table 3.2). This fit has a $\mathrm{R}^{2}$ of 0.928 . This very high $\mathrm{R}^{2}$, indicates that the data are not scattered, and there is $99.9 \%$ confidence that the regression slope is significantly different from zero, an indication the erosion rate is positively correlated with average precipitation rate. As the percentage of high precipitation days within an interval increases there is in an increase in the rate of retreat. Table 3.2 shows that the point cloud interval data plus the extreme erosion data point was fitted with a line, $\mathrm{y}=-4.023+1.27 \mathrm{x}$ where $\mathrm{y}$ is retreat rate in $\mathrm{m} / \mathrm{yr}$ and $\mathrm{x}$ is the percentage of days in which $\geq 0.015 \mathrm{~m}$ of precipitation occurred. This regression has a $R^{2}$ of 0.378 and a $90.5 \%$ confidence that the slope of the line is significantly different than zero. Instead of a linear trend, this graph suggests a threshold behavior where a small increase past $10 \%$ days where $\geq 0.015 \mathrm{~m}$ of precipitation occurs, results in a large increase in the retreat rate. 


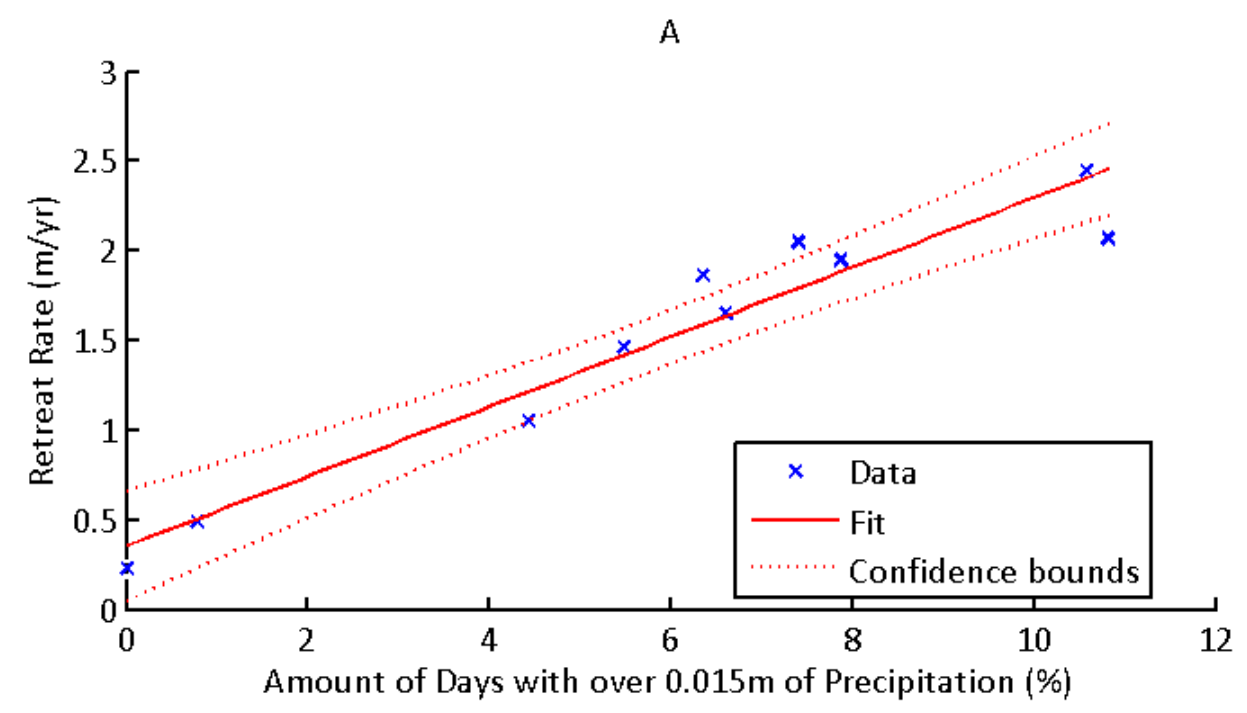

B

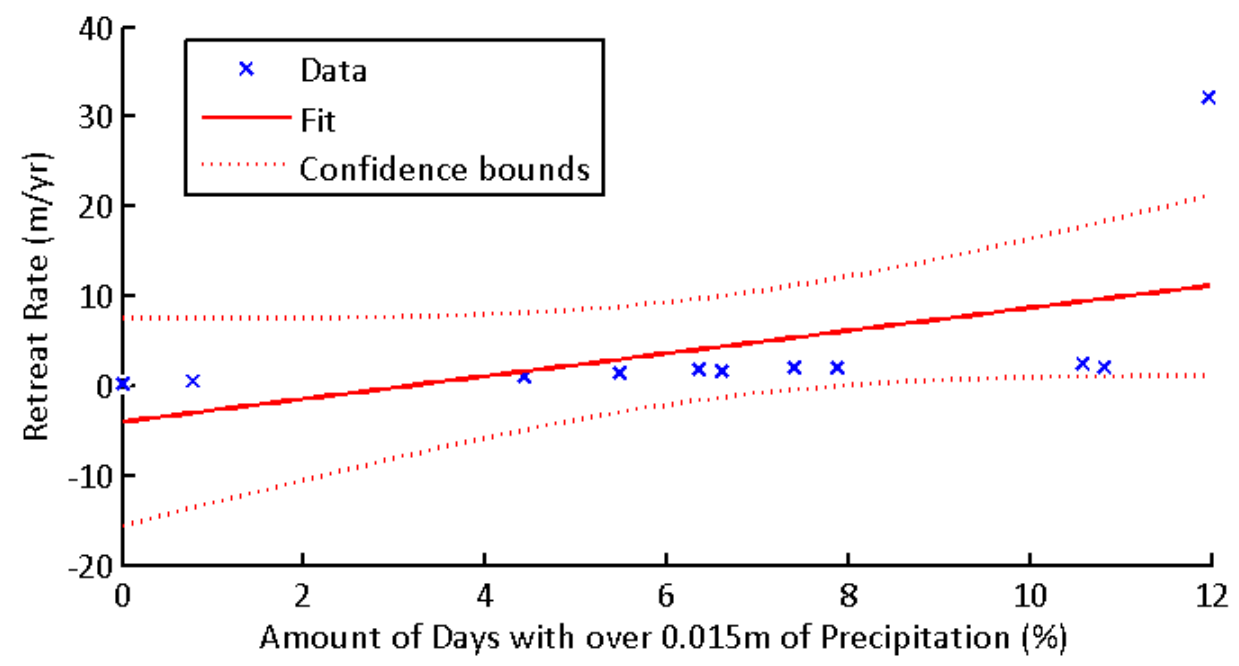

Figure 3.24: (A) Plot of the percentage of days during the interval in which over $0.015 \mathrm{~m}$ of precipitation occurred vs point cloud based retreat rate. (B) Shows percentage of days during the interval in which over $0.015 \mathrm{~m}$ of precipitation occurred plotted against the point cloud data with the extreme erosion data point included. The dashed red lines show the boundary of the $95 \%$ confidence on the slope of the data points. The solid red line is a linear regression trend. 


\subsection{Discussion}

By limiting the analysis to the subset of points for which the interval pair knickpoint faces overlapped, I was able to isolate the erosion as the knickpoint retreated upstream. The amount of overlap for each pair of knickpoint faces is reported in Table A3 and all pairs had more than $90 \%$ of their cells match. This means that more than $90 \%$ (the minimum amount of matching cells for the differenced intervals) of the measured volume of erosion was based on point to point distance, with less than $10 \%$ based on point to interpolated surfaces or interpolated surface to interpolated surface. Although erosion clearly occurred at the knickpoint face, a significant amount of additional erosion occurred in the areas immediately surrounding the knickpoint face, as well as up and downstream, but were not reported as part of the results.

Table 3.3 shows that an increase in the time between the interval pairs equated to larger root mean square error (RMSE) of alignment. The largest time span of 457 days has an RMSE of alignment of $0.05706 \mathrm{~m}$ and MDD of $0.05759 \mathrm{~m}$. The number of points and point density of the SfM based point cloud were comparable to the point clouds collected with TLS. However, the uncertainty on point location and resulting MDD was much higher for pairs of scenes that included the SfM point cloud. For example, the RSME on the alignment of consecutive TLS point clouds ranged from 3 - 4 mm but was two to ten times higher, at $10-30 \mathrm{~cm}$ for pairs of consecutive TLS and SfM point clouds.

Intervals pairs that included the SfM data in most cases showed a higher RMSE of alignment due to the uncertainty inherent in point cloud construction from photographs. However, when the error is propagated, the MDD values for the pairs that contain SfM 
data are both above and below the MDD of the TLS only pair counterparts. An increase in time span also corresponded with a greater amount of measured erosion. In general the increase in both MDD and amount of knickpoint retreat with time pan balance out: the amount of upstream retreat is consistently one or two orders of magnitude higher than the calculated MDD. The measurement with the least control on error, $-12.5 \mathrm{~m}$ of retreat between 11/18/2016 and 4/09/2017 was three orders of magnitude greater than the precision of a tape measure with millimeter tick marks.

Table 3.3: Point cloud error propagation. Cumulative error for each interval in meters. This represents the minimal detectable difference.

\begin{tabular}{cccccc}
\hline Scene 1 & Scene 2 & $\begin{array}{c}\text { Scene 1 } \\
\text { RMSE } \\
\text { of } \\
\text { Alignment } \\
(\mathrm{m})\end{array}$ & $\begin{array}{c}\text { Scene 2 } \\
\text { RMSE of } \\
\text { Alignment } \\
(\mathrm{m})\end{array}$ & $\begin{array}{c}\text { Interval } \\
\text { Pair } \\
\text { RMSE } \\
\text { of } \\
\text { Alignment } \\
(\mathrm{m})\end{array}$ & $\begin{array}{c}\text { Minimum } \\
\text { Detectable } \\
\text { Difference } \\
\text { (MDD) } \\
(\mathrm{m})\end{array}$ \\
\hline $8 / 19 / 2015$ & $10 / 23 / 2015$ & 0.00474 & 0.00789 & 0.00410 & 0.01007 \\
$8 / 19 / 2015$ & $4 / 29 / 2016$ & 0.00474 & 0.00789 & 0.01491 & 0.01752 \\
$8 / 19 / 2015$ & $9 / 5 / 2016$ & 0.00474 & 0.00755 & 0.00424 & 0.00987 \\
$8 / 19 / 2015$ & $11 / 18 / 2016$ & 0.00474 & 0.00619 & 0.05706 & 0.05759 \\
$10 / 23 / 2015$ & $4 / 29 / 2016$ & 0.00789 & 0.00789 & 0.03192 & 0.03381 \\
$10 / 23 / 2015$ & $9 / 5 / 2016$ & 0.00789 & 0.00755 & 0.01386 & 0.01764 \\
$10 / 23 / 2015$ & $11 / 18 / 2016$ & 0.00789 & 0.00619 & 0.01513 & 0.01815 \\
$4 / 29 / 2016$ & $9 / 5 / 2016$ & 0.00789 & 0.00755 & 0.01376 & 0.01757 \\
$4 / 29 / 2016$ & $11 / 18 / 2016$ & 0.00789 & 0.00619 & 0.01443 & 0.01757 \\
$9 / 5 / 2016$ & $11 / 18 / 2016$ & 0.00755 & 0.00619 & 0.00320 & 0.01028 \\
\hline
\end{tabular}

Table 3.3 shows the individual RMSE calculations for each part of the interval pairs and the total error (MDD) based on Gaussian Error propagation. The point cloud from 4/29/2016, based SfM photo processing, was not the result of individual point clouds merged together and did not have an RMSE associated with its merged alignment. I used the highest value of RMSE of alignment from the TLS data sets as a minimum 
substitute in the calculation of MDD for interval pairs that include this data. The data collection methods, described earlier, resulted in low total RMSE values showing that the erosion measured at the knickpoint face between interval pairs was greater than the statistically defined minimum detectable difference.

There is positive (slope of regression > zero) linear correlation between cumulative precipitation and retreat rate when the extreme event is excluded. This confirms my hypothesis that an increase in precipitation would result in a linear increase in erosion rate under conditions that exclude extreme erosion. There is not a significant linear correlation between total precipitation and retreat rate when the extreme erosion data point is included. This may indicate that the retreat rates and total precipitation associated with extreme erosion intervals behave nonlinearly. The retreat rate of the extreme erosion event is assumed to be the combined product of all three erosion mechanisms, but as noted earlier, block failure at the face and undercutting at the plunge pool contribute most to upstream retreat. Turbulent scour and stress deformation from intense discharges across the knickpoint face can lead to block failures and undercutting (Simon et al., 2000). The total precipitation recorded during the extreme event interval does not adequately capture the maximum intensity of precipitation and therefore does not capture the maximum intensity of discharge felt at the knickpoint lip and face that could lead to the extreme erosion based retreat rate.

There is not a linear correlation between number of wetting and drying cycles between TLS interval pairs only and retreat rate when the extreme event is included or excluded, or when the three time intervals with observed exfoliation sheeting were 
analyzed. Erosion by wetting and drying cycles can be both a chemical and mechanical process during which a previously wet substrate is allowed dry to a point where cracks or zones of weakness develop. The observed year round discharge in the channel may only allow isolated segments of the substrate to undergo the drying necessary for this abiotic process to cause erosion (Dietrich et al., 2003). The lack of correlations may indicate either that wetting or drying cycles of the soil composing the channel are not ample enough, and contributes little to the knickpoint retreat rate or during intervals when a combination of erosion patterns were observed, the signal of wetting and drying cycles is muted. However, during three intervals when the dominant erosion observed was exfoliation, the corresponding number of wetting and drying cycles was much more strongly correlated with retreat rate, and is therefore more likely a primary driver. This was supported by very strong $R^{2}$ of 0.99 between retreat rate and number of wetting/drying cycles. The confidence that the slope of the regression is positive and greater than zero is slightly less (94.1\%) than my 95\% threshold for significance. Although the sample size was small, for intervals when the retreat rates were relatively low, the exfoliation process accounted for the majority of the total erosion. The seasonal timing of these intervals (two from spring/summer and one from early fall) may indicate that during times of infrequent but heavy precipitation events, exfoliation based erosion is dominant.

There is a positive (slope of regression > zero) linear correlation between average precipitation rate between point cloud interval pairs only and retreat rate. There is not a significant linear correlation between average precipitation rate and retreat rate when the 
extreme erosion data point is included. The interval-averaged precipitation rate is a proxy for the average discharge felt across the knickpoint face. This average discharge directly contributes to average erosion at the knickpoint face. This erosion at the face was used to calculate the average retreat rate. It is assumed that intense discharge (well above average) is responsible for the extreme erosion event. The retreat rates increase gradually below $2 \mathrm{~m} / \mathrm{yr}$; at greater rates the retreat rate is highly variable. This may indicate that shorter time intervals to measure more realistic retreat and precipitation rates are required to better define this relationship.

There is a positive linear correlation between percentage of days when $\geq 0.015 \mathrm{~m}$ of precipitation occurred between point cloud interval pairs only and retreat rate. This precipitation metric may act as proxy for maximum precipitation intensity and therefore the maximum discharge intensity felt across the knickpoint face. This intensity proxy may capture some of the physical processes (direct scour and abrasion from flowing water) that contributes to two major erosion mechanisms: block failure and undercutting. There is not a significant linear correlation between percentage of days when $\geq 0.015 \mathrm{~m}$ of precipitation occurred and retreat rate when the extreme erosion data point is included. This may indicate that the retreat rates and amount of heavy precipitation associated with extreme erosion intervals behave nonlinearly. Specifically, the erosion rate for a time interval including the extreme erosion data point may cross a threshold at about $10 \%$ of that interval during which $0.015 \mathrm{~m}$ or more precipitation occurred. This may indicate that erosion rates increase rapidly during time intervals when the percentage of days when $\geq$ $0.015 \mathrm{~m}$ of precipitation occurred is greater than $10 \%$. These extreme erosion events and 
their associated precipitation, rapidly contribute to that period's total measure of erosion, directly factoring into the retreat rate. A rare but large erosion event can dominate the retreat rate of the knickpoint face over the long term. This implies that future mitigation and management of the knickpoint retreat must focus on the discharge from large storm events as well as time intervals with many large storm events (a preliminary threshold of $10 \%$ of days per interval), which push the retreat rates to extremes

Using point cloud analysis and examining multiple time intervals allowed the patterns of erosion and hydrologic controls on that erosion to be revealed. During the dry months (end of spring to early fall) of the water year exfoliation based erosion is likely to contribute to the relatively slow retreat of the knickpoint. During the wetter months of the water year (late fall through spring), moderate but frequent precipitation leads to block failures and undercutting based erosion at the knickpoint face, which accounts for the majority of the net erosion during this interval. Additionally, even over a short interval (about five months) a particularly large storm event or series of large storms can push the system past a threshold and cause very rapid retreat to occur. This previous analysis and resulting retreat rates pertains to relative changes to the knickpoint face. In order to gain insight on the mode of retreat and how this knickpoint behaves relative to the channel, a detailed examination of the substrate under erosion is presented in the following section. 


\section{Soil Analysis}

\subsection{Introduction}

Determining some basic characteristics about the soil substrate undergoing erosion aids understanding of the erosion patterns observed. Loess (wind-blown silt) is present in the lower Willamette Valley, a byproduct of the Missoula Floods deposits (Evarts et al., 2009). The loess layers present at the study site are observed to be cohesive and laterally uniform. Trimble (1963) described the local loess deposits as yellowish-brown silt, structureless, and homogeneous, yet the erosion into loess documented above was not uniform and appeared to be controlled by subtle structures. This material is the sediment under denudation, making up the geologic substrate of the channels and knickpoints.

The majority of research done on loess and its erosion is focused on China's Loess Plateau, a region with some of the highest erosion rates in the world, up to 18,000 tons $/ \mathrm{km}^{2} /$ year or $0.9 \mathrm{~cm} / \mathrm{yr}$ (assuming an average soil density of 2,000 kg/m $\mathrm{m}^{3}$ ), and complex land use issues (Hessel and Van Asch, 2003). Larger than $300,000 \mathrm{~km}^{2}$, this loess dominated landscape with 7,000 years of human occupation serves as an example of an extreme case of the mix of erosion in loess and land use (Xinbao et al., 1990). Studies using empirical models suggest that a shrinkage in cropland and/or an expansion in woodland decreases catchment-averaged erosion rate (Hessel et al., 2003; Feng et al., 2010). The erosion of loess from the plateau is the main source of sediment pollution in the lower reaches of the Yellow River (Fu et al., 2009). On a much smaller scale the Bull Mountain study area has undergone a similar transition from woodland to cropland and finally to a highly urbanized environment. 
In addition to the type of soil in the channel and the local land use history, the easily measurable physical characteristics and stratigraphy of the soil can help explain the observed patterns of erosion. Traditionally fragipans are common in loess and can be identified by bulk densities usually greater than $1.6 \mathrm{~g} / \mathrm{cm}^{3}$, or higher than those of the overlying horizon (Birkeland, 1999). In the United States, work in and along the Mississippi River Valley suggests that in loess dominated landscapes the relationship between bulk density and fragipans is more complicated, with a range of densities for fragipans from 1.45 to $1.78 \mathrm{~g} / \mathrm{cm}^{3}$ (Lindbo et al., 1994). The Cornelius and Kinton silt loams mapped in the area have reported bulk densities ranging from $1.13-1.58 \mathrm{~g} / \mathrm{cm}^{3}$ (Green, 1982). Other characteristics of fragipans include development time of several thousand years and a moist climate(Assallay et al., 1998; Smalley et al., 2015). In this study, local variations in relative density (rather than an absolute density threshold) and strength were measured to identify fragipan layers and help determine knickpoint retreat mode.

\subsection{Methods}

To characterize the loess substrate, I took soil samples in and around the Morningstar Creek knickpoint. I collected 14 soil samples using an improvised Shelby tube made from $2 \mathrm{~cm}$ inside diameter schedule 40 copper pipe. At the knickpoint, I defined a vertical transect that extends from the base of the knickpoint plunge pool to the highest channel bank above the knickpoint (the vertical extent of the exposed loess in Figure 3.17), and collected samples at a spacing of $\sim 1 \mathrm{~m}$. I also took samples farther downstream, on the 
bed of the channel, at block failure features, and at the relict knickpoint faces. Relict knickpoint faces were intact loess in the vertical structure along the channel sides consistent with the approximate location of previously recorded knickpoint faces.

The sample collection took place on 4/9/2017 (Fig. 4.1). The soil was sampled by pounding in a length of copper pipe into the exposed soil until it was flush with the surface, then digging out the tube with the soil intact. The samples were sealed in a zip top plastic bag to retain in situ moisture. I recorded in situ shear stress at some of the sample sites using a pocket Torvane instrument. I found the moist mass of these samples, dried them in an oven for 24 hours at $105^{\circ} \mathrm{C}$, then found the dry mass. The oven dried samples are shown in Figure 4.2a. The difference in mass gave me the moisture content. The dry bulk density was calculated by measuring the diameter and length of the tube of soil for the volume in each and determining its mass. I established grain size distribution by a hydrometer settling test following ASTM D422 for three of the samples. The hydrometer test setup is shown in Figure 4.2b. 


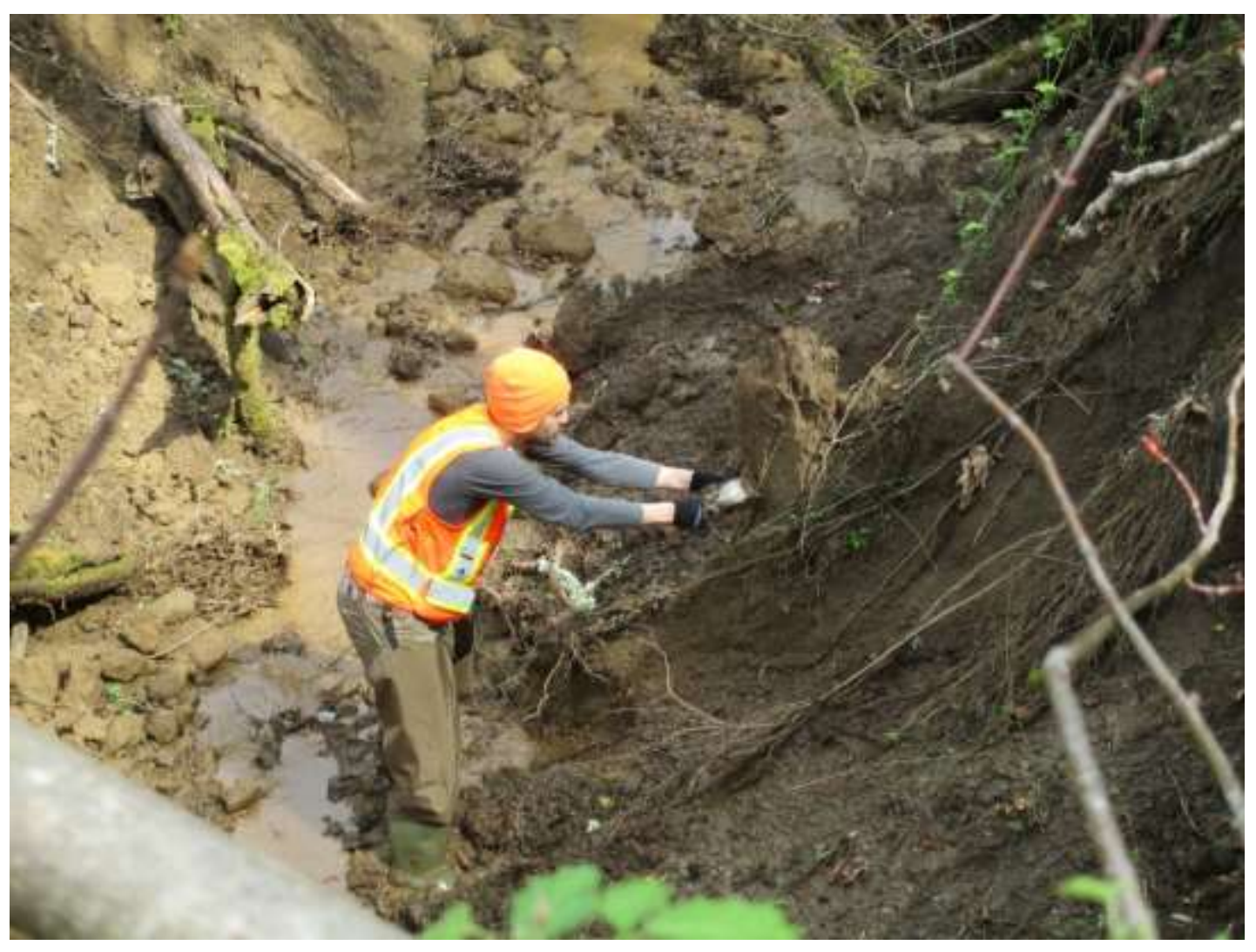

Figure 4.1: A photograph of the author collecting soil samples from the channel. Here a sample is taken from an observed relict knickpoint face on 4/9/2017. 


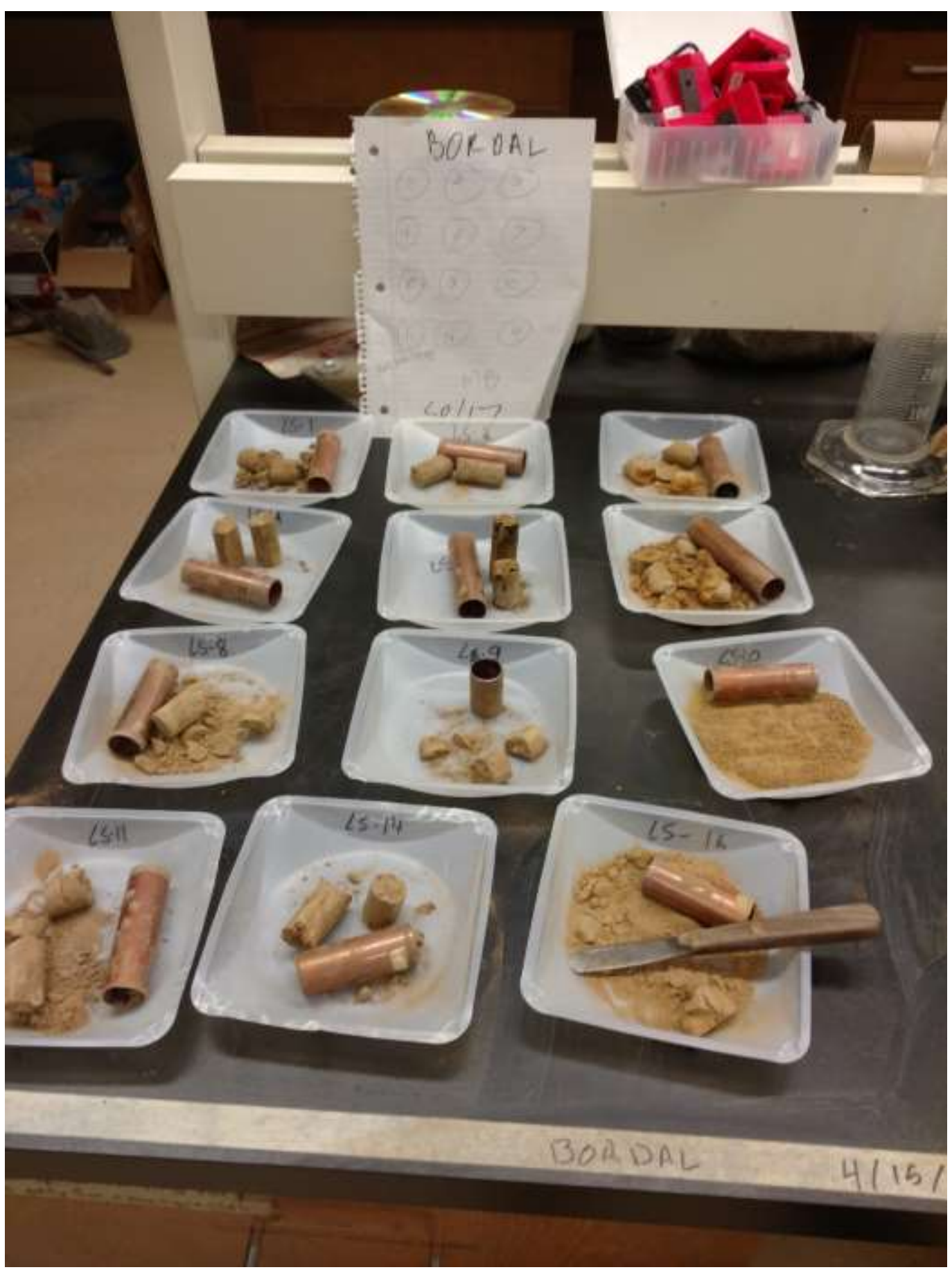

Figure 4.2a: Oven dried soil samples. Also shown are the individual copper collection tubes. 


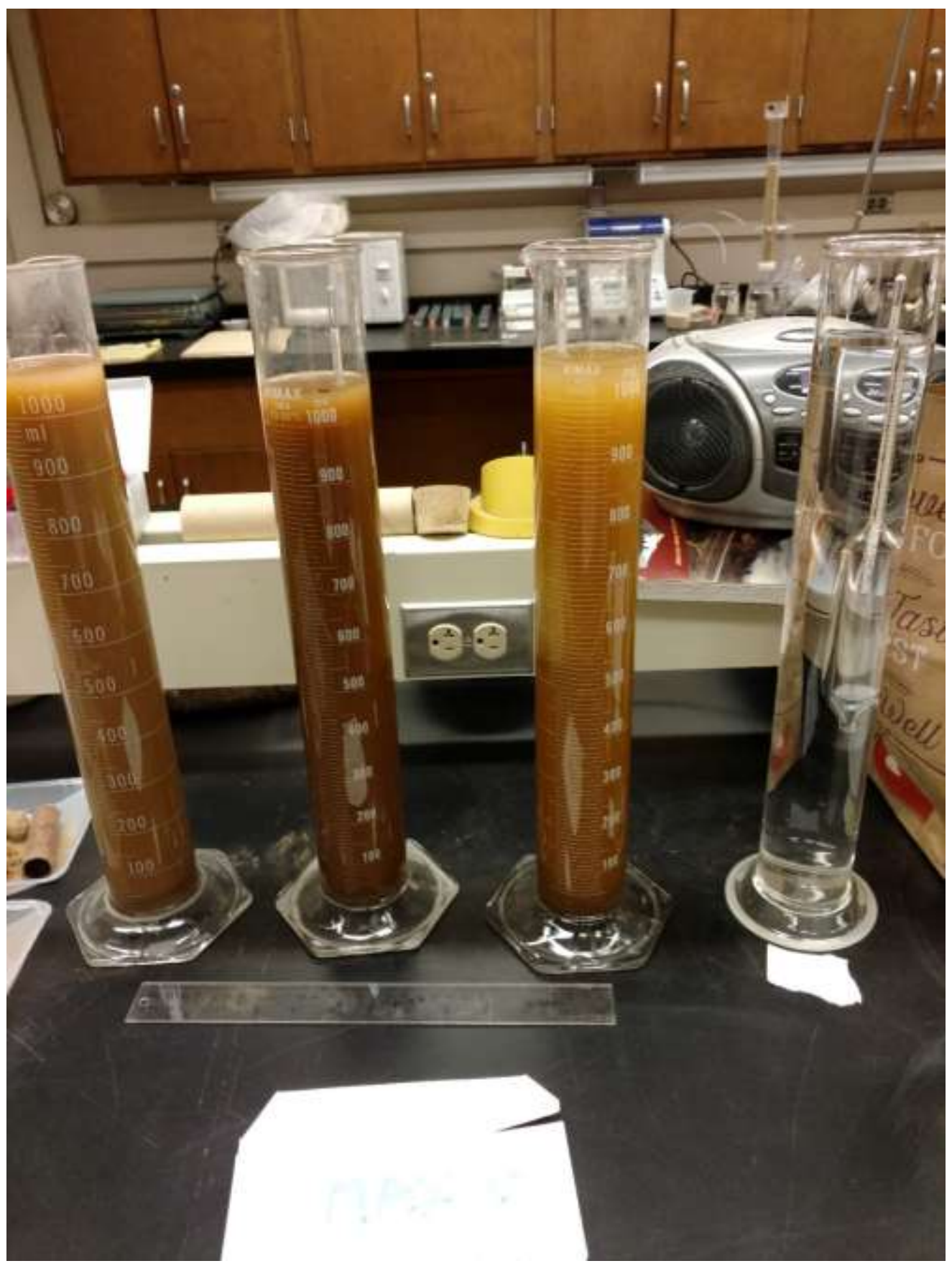

Figure 4.2b: Four hydrometers set up for the grain size analysis. The far right graduated cylinder acted as a control and only contained deionized water. 


\subsection{Observations and Results}

After the transition from field moist to oven dried, the samples retained a high degree of cohesion. It was difficult to extract the samples from their tubes as shrinkage from the drying process was much less than anticipated. Upon inspection of the dried samples, fine sand sized muscovite grains were noted in most of the samples. In sample number 6 , located at the remains of the previous knickpoint face, small charcoal nodules were found. Samples had a varying degree of orange staining/mottling. Upon crushing and breaking up the oven dried samples, particles in the medium sand to fine silt size classes were observed.

During sample collection I could not distinguish a difference in density by feel or any classic fragipans characteristics. Table 4.1 shows the moisture content and dry bulk density for the soil samples collected. The average moisture content was $25.2 \%$ with a standard deviation of $2.01 \%$. The average dry bulk density is $1.49 \mathrm{~g} / \mathrm{cm}^{3}$ with a range of 1.204 to $1.846 \mathrm{~g} / \mathrm{cm}^{3}$. Table 4.1 shows that sample 5 , collected from the bed of the upper channel, has the highest dry bulk density of $1.85 \mathrm{~g} / \mathrm{cm}^{3}$. The next highest density is sample 7 at $1.58 \mathrm{~g} / \mathrm{cm}^{3}$ which was collected at the base of lower channel. The lowest density is sample 3 at $1.20 \mathrm{~g} / \mathrm{cm}^{3}$, which was collected $4.3 \mathrm{~m}$ below the bank top, which is between the elevation of the plunge pool and the knickpoint lip. 
Table 4.1: In field and laboratory characteristics of soil samples.

\begin{tabular}{|c|c|c|c|c|}
\hline Sample & $\begin{array}{l}\text { Moisture } \\
\text { Content }\end{array}$ & $\begin{array}{l}\text { Density } \\
\left(\mathrm{g} / \mathrm{cm}^{3}\right)\end{array}$ & $\begin{array}{c}\text { Torvane } \\
\text { Derived } \\
\text { Shear } \\
\text { Strength } \\
\left(\mathrm{kg} / \mathrm{cm}^{2}\right)\end{array}$ & Sample Notes \\
\hline 1 & 0.253 & 1.499 & 0.25 & $\begin{array}{l}\text { At knickpoint face } 3.5 \mathrm{~m} \\
\text { below bank top }\end{array}$ \\
\hline 2 & 0.232 & 1.463 & 0.25 & $\begin{array}{l}\text { at knickpoint face } 2.5 \mathrm{~m} \\
\text { below bank top }\end{array}$ \\
\hline 3 & 0.282 & 1.204 & $\mathrm{X}$ & $\begin{array}{c}\text { At knickpoint face } 4.3 \mathrm{~m} \\
\text { below bank top }\end{array}$ \\
\hline 4 & 0.254 & 1.500 & $\mathrm{x}$ & Relict knickpoint face \\
\hline 5 & .201 & 1.846 & 0.9 & Base of upper channel \\
\hline 6 & 0.262 & 1.456 & $\mathrm{x}$ & $\begin{array}{l}\text { November } 2016 \text { relict } \\
\text { knickpoint face }\end{array}$ \\
\hline 7 & 0.230 & 1.575 & 0.4 & $\begin{array}{l}\text { Base of lower channel } \\
\text { downstream west side }\end{array}$ \\
\hline 8 & 0.266 & 1.450 & 0.25 & $\begin{array}{l}\text { Base of channel near relict } \\
\text { knickpoint }\end{array}$ \\
\hline 9 & 0.266 & 1.470 & $\mathrm{x}$ & $\begin{array}{l}\text { At knickpoint face } 4.4 \mathrm{~m} \\
\text { below bank top }\end{array}$ \\
\hline 10 & 0.261 & 1.468 & $\mathrm{x}$ & Base of channel \\
\hline 11 & 0.251 & 1.467 & $\mathrm{x}$ & $\begin{array}{l}\text { Tabular block of soil }(36 \mathrm{~cm} \mathrm{x} \\
18 \mathrm{~cm}) \text { near stream base }\end{array}$ \\
\hline 14 & 0.253 & 1.492 & $\mathrm{x}$ & Lip of knickpoint \\
\hline 16 & 0.269 & 1.449 & $\mathrm{x}$ & $\begin{array}{c}\text { Base of plunge pool above } \\
\text { water line } 4.4 \text { below bank top }\end{array}$ \\
\hline Mean & 0.252 & 1.488 & & \\
\hline
\end{tabular}


Figure 4.3 plots the five in-situ shear stress measurements taken in the field.

These five values and their corresponding dry bulk density measurement are linearly proportional with the equation $\mathrm{y}=-2.2666+1.7085 \mathrm{x}$ where $\mathrm{y}$ is the shear stress in units of $\mathrm{kg} / \mathrm{cm}^{2}$ and $\mathrm{x}$ is density in $\mathrm{g} / \mathrm{cm}^{3}$. The $\mathrm{R}^{2}$ value for this linear regression is 0.986 . There is $99.9 \%$ confidence that the slope of the regression is greater than zero.

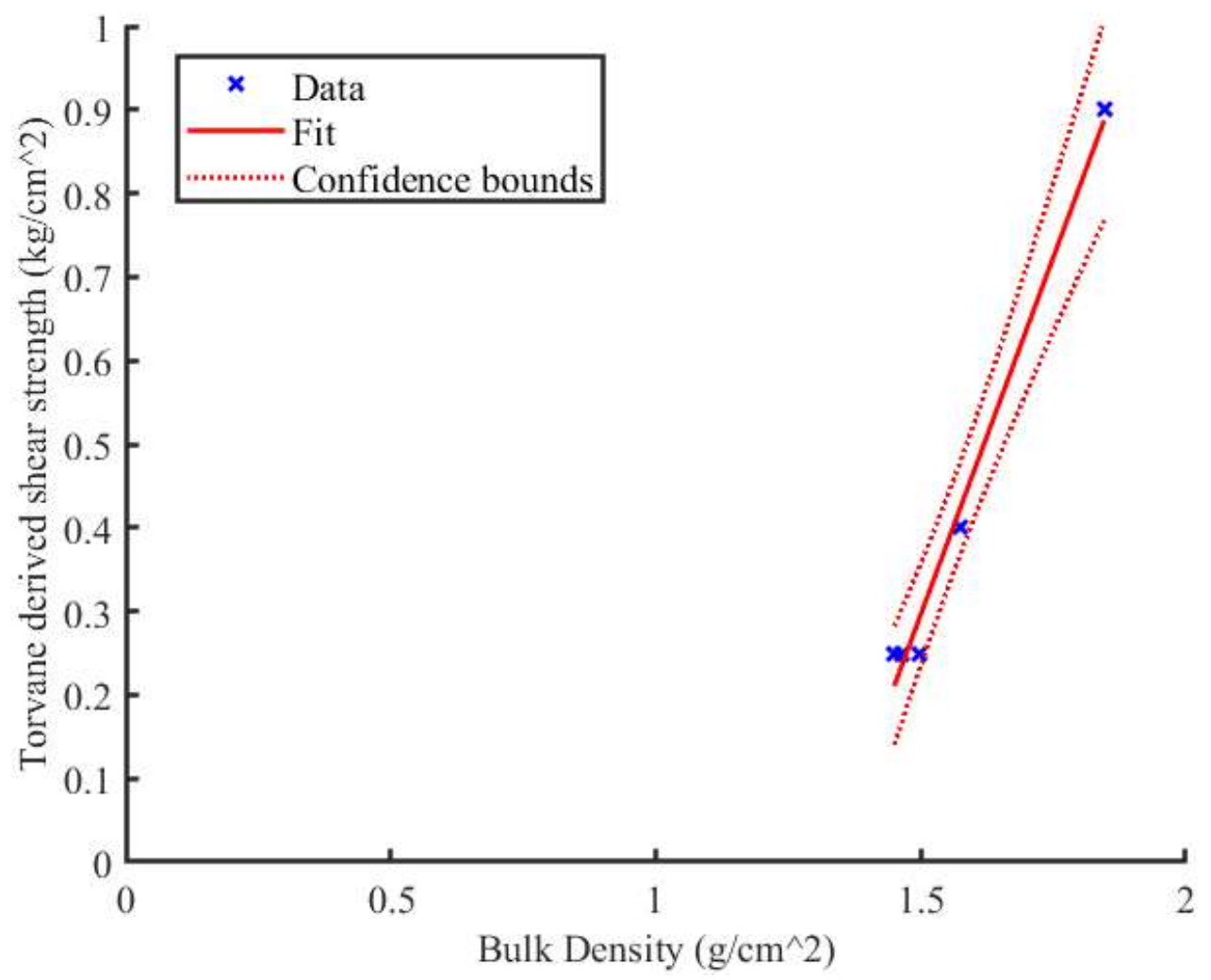

Figure 4.3: Plot showing bulk density as a function of Torvane derived shear strength. This includes five data points (samples 1, 2, 5, 7, and 8) corresponding to locations around the knickpoint where soil was sampled and a Torvane reading was recorded. The dashed red lines show the boundary of the $95 \%$ confidence on the slope of the data points. The solid red line is a linear regression trend.

Figure 4.4 shows grain size distribution of three samples (\# 1 from $3.5 \mathrm{~m}$ below the back at the face, \# 7 from the base of lower channel along western bank, and \# 10 
from the base of lower channel) as determined by a hydrometer settling test. These three samples had the total masses required for the test. In sample $7,47 \%$ of the particles are finer than $0.036 \mathrm{~mm}$; in sample $1,48 \%$ of the grains are finer than $0.035 \mathrm{~mm}$; in sample $10,36 \%$ of the grains are finer than $0.037 \mathrm{~mm}$. Figure 4.4 shows the convergence of the three gradation curves at the fine end of the distribution. All three samples contain at least $23 \%$ of grains finer than $0.0014 \mathrm{~mm}$ at the end of the 24 hour test period, which are considered clays. 


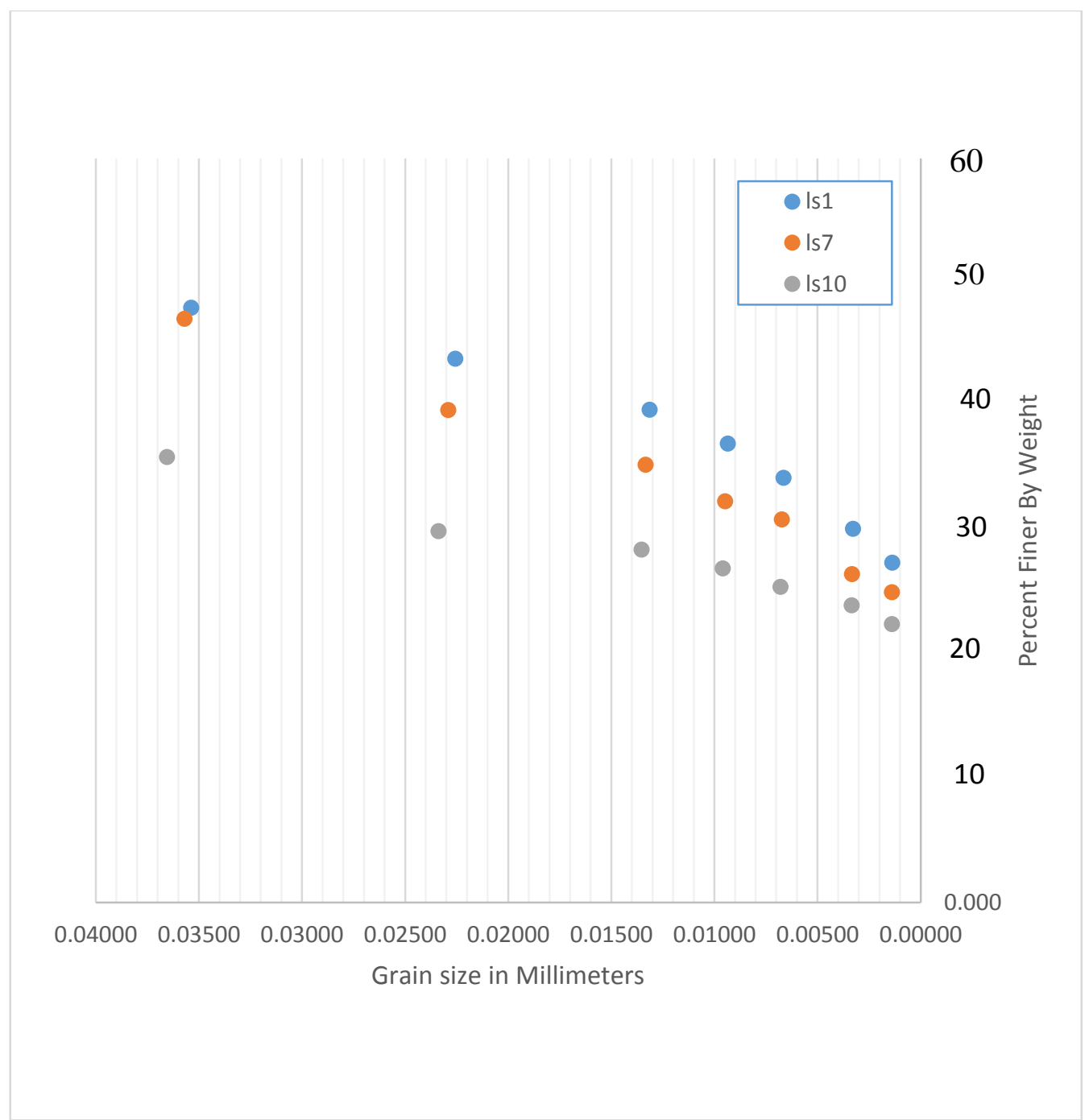

Figure 4.4: Gradation curve showing grain size distribution from fine sand to clay for samples 1,7 , and 10 . 


\subsection{Discussion}

In the field, no distinctions of density, texture, or moisture content could be made through visual or tactile observations. Laboratory analysis of the soils in and around the knickpoint suggests there are distinct changes in relative bulk dry soil density. The locations of these density contrasts correspond to the geometrically defining parts of the knickpoint, so I therefore infer that they are a leading factor in the height and shape of the knickpoint. The grain size distribution is further corroborating evidence that the substrate was correctly identified in the field as loess, as the three gradation curves visually match established trends for loess (Gibbs and Holland, 1960).

The extremely small variance of moisture content among the samples indicates a uniform moisture content. This may indicate a consistent influence of groundwater on the substrate. This helps eliminate that variable when considering the results of the shear strength tests.

The shear strength values from the Torvane instrument in the field are strongly correlated to the density measurements determined in the laboratory. The high correlation coefficient between these two independent tests helps affirm that density is a good proxy for shear strength in loess at the study site. Furthermore, strength increases relatively rapidly with density, such that shear strength approximately quadruples as density increases from 1.4 to $1.8 \mathrm{~g} / \mathrm{cm}^{3}$. The location of the highest density and highest Torvanederived shear strength sample confirms my hypothesis that a resistant layer of soil is present at the bed of the upper channel. In this case a soil with fragipan characteristics is limiting the downcutting of the upper channel and is controlling the elevation of the 
knickpoint lip. The lower soil density values observed on the face of the knickpoint underlay this high density and strong layer of soil, consistent with parallel retreat mode (Fig 3.2) (Gardner, 1983). The second highest soil density was observed at the base of the lower channel. This could indicate a controlling layer limiting incision of the lower channel as well, thereby setting the knickpoint height. No diffusion or change in relative angle of the knickpoint face was observed (see section 3). The direct observation of the knickpoint face traveling upstream under a parallel retreat mode is further evidence that a resistant layer at the lip of the knickpoint face is present. 


\section{Establishing Erodibility (K) for Loess}

\subsection{Introduction}

The erosion in a channel is often modeled using the stream power river incision law (Eq. (1.1)), Howard and Kerby, 1983). In contrast to this study, much of the previous research quantifying rates of loess erosion focused on non-channeled surfaces and relied on the Revised Universal Soil Loss Equation (RUSLE) or a storm focused model, the Limburg Soil Erosion Model (LISEM) (Hessel et al., 2003; Fu et al., 2009; Feng et al., 2010). The RUSLE is empirically based and the LISEM uses empirically derived equations. These approaches to modeling erosion work best for sheetwash on barren hillslopes and will not be adequate for my study of channel based erosion.

Alternatively a physically based model, based on conservation laws, can be used to explore sediment transport, and offers great flexibility (Aksoy and Kavvas, 2005;

Pelletier, 2008). Jet tests are an example of a physically based model and a common way to measure erodibility. These tests involve submerging a water jet with a known velocity to cause incision of the bed material, in order to compute the hydraulic shear stress being applied (Marot et al., 2011). Jet test studies can determine a value for erodibility (based on shear stress) in-situ. Erodibility is a key parameter in such physically based models, through the forced erosion, $\mathrm{Ej}(\mathrm{L} / \mathrm{T})$, of a channel's substrate,

$$
E_{j}=K_{j}\left(\tau-\tau_{c r i t}\right)
$$

where $\mathrm{K}_{\mathrm{j}}$ is erodibility $\left(\mathrm{L}^{3} / \mathrm{F}-\mathrm{T}\right)$, and $\tau-\tau_{\text {crit }}(\mathrm{Pa})$ is the difference between bed shear stress and critical shear stress necessary to induce detachment (Simon et al., 2000).. The site specific values of erodibility from jet tests have been found to be higher than empirically 
based values (Clark and Wynn, 2006). It is important to measure soil erodibility in the field because these values are sensitive to a suite of factors including compaction, soil texture, and plasticity (Hanson and Hunt, 2007). A novel approach to estimate erodibility, which does not require any special equipment, is to exploit the relationships between the physical process parameters in the stream power equation (a derivation is presented below).

The erosion in a river system is often occurring under one of two limitations: either the ability of the flow to transport available sediment or the ability of the flow to detach sediment from the bed. The term transport limited is applied to streams where the erosion is controlled by the channel's capacity to transport sediment away (Brush and Wolman, 1960); the term detachment limited is applied to streams where the erosion is controlled by the channel's capacity to cut through the geologic substrate. The ability to model channel erosion with the stream power law relies on the assumption of detachment limited conditions (Howard and Kerby, 1983). The upper reaches of Morningstar Creek channel, where the knickpoint is located, exhibit little to no sediment accumulation, have flow year round, and no instream vegetation, factors indicating a detachment limited assumption is reasonable.

Section 3 reported the observed erosion rates at the Morningstar Creek knickpoint. Here I use those rates to back calculate the erodibility constant $\mathrm{K}$ using a derivation of the stream power law. This parameter $\mathrm{K}$ represents how easy the substrate is to be eroded, incorporating the effects of watershed and channel geometry. I then compare my $\mathrm{K}$ values, from this novel estimation technique, to other studies that have 
estimated erodibility from the assumption of steady - state channel form. The erodibility parameter $\mathrm{K}$ used in this study is different and not interchangeable with the erosion factor $K$ found in soil surveys based on the RUSLE.

\subsection{Methods}

Following the principle of conservation of mass, in a closed system, if the elevation at a point is increasing or decreasing, sediment must be transported to and from another point, through erosion and/or deposition (Tucker et al., 2001). I use the assumption that erosion rate is proportional to the rate of energy expenditure by flowing water such that,

$$
\mathrm{E}=\mathrm{K}_{\mathrm{p}}(\tau \mathrm{V})^{\mathrm{a}}
$$

where erosion rate $E(L / T)$ is a function of shear stress $\tau(p)$ and average velocity of flow $\mathrm{V}(\mathrm{L} / \mathrm{T})$. This is known as the unit stream power where $\mathrm{K}_{\mathrm{p}}$ and a are positive constants (Whipple and Tucker, 1999). This model assumes that erosion occurs under high discharge regimes where shear stress is much greater than critical shear stress (Howard and Kerby, 1983).

The following substitutions and assumptions allows me to re write Eq. (5.2) in terms that can be applied to and measured at this study's knickpoint. Assuming steady uniform flow, the erosion rate can be estimated using,

$$
\mathrm{E}=K_{p}((\gamma d S) V)^{a}
$$

where shear stress $\tau$ is the product of the unit weight of water $\gamma\left(\mathrm{F} / \mathrm{L}^{3}\right)$, the depth of the water d (L), and the slope of the channel S (L/L) (Whipple and Tucker, 1999). 
It is assumed that discharge is equal to average velocity multiplied by depth (L) multiplied by channel width (L), so velocity and channel depth can be eliminated for Eq. (5.3) (Sklar and Dietrich, 1998). This substitution lead to

$$
\mathrm{E}=K_{p}\left[\begin{array}{ll}
(\rho g S) & \frac{Q}{W}
\end{array}\right]
$$

Here $\mathrm{g}$ is acceleration due to gravity $\left(\mathrm{L} / \mathrm{T}^{2}\right), \rho$ is fluid density $\left(\mathrm{M} / \mathrm{L}^{3}\right), \mathrm{W}$ is channel width (L), $\mathrm{S}$ is slope $(\mathrm{L} / \mathrm{L})$, and $\mathrm{Q}$ is discharge $\left(\mathrm{L}^{3} / \mathrm{T}\right)$; exponent a is assumed to be one because it is dependent on the dominant erosion mechanics, which are often unknown (Whipple, Hancock, et al., 2000; Sklar and Dietrich, 1998). Although this derivation started by assuming erosion rate is a function of unit stream power, an equivalent derivation beginning with the assumption that erosion is a function of shear stress, as in Eq. (5.1), shows that the shear stress equation is at the basis of the stream power law (Julien, 2010). Commonly drainage area A serves as a proxy for $\mathrm{Q}$, because an average effective precipitation rate multiplied by the drainage area determines the average effective discharge (Whipple and Tucker, 1999).

If discharge varies with drainage area and width varies with discharge, and each are scaled by dimensional constants $\mathrm{k}_{\mathrm{a}}, \mathrm{k}_{\mathrm{a}}{ }^{\mathrm{b}}$, and $\mathrm{k}_{\mathrm{w}}$ (Sklar and Dietrich, 1998), then replacing the $\mathrm{Q}$ and $\mathrm{W}$ terms in Eq. 5.4 results in, 


$$
\mathrm{E}=\frac{K_{p} \rho g S}{k_{w}} \frac{k_{a}}{k_{a}^{b}} \frac{A^{r}}{A^{r b}}
$$

where exponents, $\mathrm{r}$ and $\mathrm{rb}$ are positive constants. After some simplification this results in

$$
\mathrm{E}=K A^{r(1-b)} S
$$

where K is now a multivariate constant (Whipple and Tucker, 1999). Specifically consolidating the coefficients define the erodibility constant, $\mathrm{K}$, in Eq. (5.5b), as:

$$
\mathrm{K}=\mathrm{K}_{\mathrm{p}} \rho g k_{a}^{1-b} / k_{w}
$$

where relationships between flow hydraulics, channel geometry and catchment hydrology are all incorporated into the coefficient exponents (Whipple and Tucker, 1999).

A more general form of the stream power law shown in Eq. (5.5b) defines erosion rate as,

$$
\mathrm{E}=\mathrm{K} A^{m} S^{n}
$$

where incision rate is a power function of drainage area and slope, and $\mathrm{m}$ and $\mathrm{n}$ are positive constants that control the dominance of $\mathrm{A}$ and $\mathrm{S}$, while term $\mathrm{K}$ is an erodibility constant representing substrate strength, hydraulic geometry, changes in discharge and sediment supply, geometric scaling effect, and physical properties of the channel (Sklar and Dietrich, 1998). The erodibility constant K (Eq. (5.6)) is fundamentally connected to the Kj term (Eq. (5.1)) used in the jet test equation, but since most parameters in Eq. (5.5c) are difficult to measure accurately, I do not compare these two erodibility constants in this study. For the stream power erodibility parameter, influencing factors 
include drainage basin-wide characteristics such as lithology, climate and hydraulics, which leads to units of $\mathrm{L}^{1-2 \mathrm{~m}} / \mathrm{T}$, while the jet test erodibility parameter $\mathrm{Kj}$, is measured in $\mathrm{L}^{3} / \mathrm{F} \mathrm{T}$ and is influenced by local factors like clay type and content, soil moisture, and soil structure (Whipple et al., 2000; Clark and Wynn, 2006). Both forms attempt to capture the erodibility of a channel's substrate, but the stream power approach includes a wide range of the watershed's physical processes while jet tests isolate the physical or engineering characteristics of the material being eroded. To gain insight into the physical processes taking place at the knickpoint face, I chose to calculate $\mathrm{K}$ using the stream power approach.

Conservation of mass in the channel is assumed, so a general equation that computes the elevation $(\mathrm{z})$ at a point $(\mathrm{x}, \mathrm{y})$ in the landscape as the difference between uplift and erosion is,

$$
\frac{\partial z}{\partial t}=U-E
$$

where $t$ is time ( T ), and $\mathrm{U}(\mathrm{L} / \mathrm{T})$ is the rate of base level lowering at the stream's outlet. Substituting Eq. (5.6) into Eq. (5.7), assuming $U=0$, and rearranging yields the upstream migration rate of a knickpoint,

$$
\frac{\partial x}{\partial t}=-\mathrm{K} A^{m}(S)^{n-1}
$$

where $\mathrm{dx} / \mathrm{dt}$ is the change in horizontal distance over the change in time. For consistency with previous work this study assumes $m=0.4$ and $n=1$. The exponent $n$ is typically fixed at a value of 1, assuming the erosion rate is proportional to average shear stress, so that the slope term, with a net exponent of zero, can be ignored (Sklar and Dietrich, 
1998). Therefore, I measured dx/dt directly with repeat TLS, as discussed in section 3 , and calculated drainage area from existing DEMs in order to solve for the bedrock erodibility, $\mathrm{K}$.

Other values of erodibility from relevant long term landscape evolution studies were compiled from literature review and included as points of comparison. The studies included calculated erodibility values in the context of the stream power equation so the units are consistent with my analysis.

\subsection{Results}

Table 5.1 shows the calculated soil erodibility values from this study and comparisons to others. The erodibility calculated from erosion rates determined from point cloud analysis ranged from 0.0016 to $0.0177 \mathrm{~m}^{0.2} / \mathrm{yr}$ with a mean of $0.0110 \mathrm{~m}^{0.2} / \mathrm{yr}$. The erodibility systematically increases with higher erosion rates, or equivalently with higher discharge since erosion rates and average precipitation rate were correlated. The highest erodibility value of $0.2322 \mathrm{~m}^{0.2} / \mathrm{yr}$, resulting from extreme erosion conditions between 11/18/2016 and 4/9/2017, was not included in the average, as it would artificially weight the statistical average. 
Table 5.1: Stream power calculated erodibility value comparison; $\mathrm{m} / \mathrm{n}=0.4 / 1.0$

\begin{tabular}{|c|c|c|c|}
\hline & & $\begin{array}{c}\text { Calculated } \\
\text { (this study) } \\
\text { or } \\
\text { Reported } \\
\text { Erodibility } \\
\mathrm{K}\left(\mathrm{m}^{0.2} / \mathrm{yr}\right)\end{array}$ & $\begin{array}{l}\text { Substrate } \\
\text { Type }\end{array}$ \\
\hline $8 / 19 / 2015$ & $10 / 23 / 2015$ & 0.0016 & Loess \\
\hline $8 / 19 / 2015$ & $4 / 29 / 2016$ & 0.0141 & Loess \\
\hline $8 / 19 / 2015$ & $9 / 5 / 2016$ & 0.0106 & Loess \\
\hline $8 / 19 / 2015$ & $11 / 18 / 2016$ & 0.0135 & Loess \\
\hline $10 / 23 / 2015$ & $4 / 29 / 2016$ & 0.0177 & Loess \\
\hline $10 / 23 / 2015$ & $9 / 5 / 2016$ & 0.0119 & Loess \\
\hline $10 / 23 / 2015$ & $11 / 18 / 2016$ & 0.0148 & Loess \\
\hline $4 / 29 / 2016$ & $9 / 5 / 2016$ & 0.0036 & Loess \\
\hline $4 / 29 / 2016$ & $11 / 18 / 2016$ & 0.0076 & Loess \\
\hline $9 / 5 / 2016$ & $11 / 18 / 2016$ & 0.0150 & Loess \\
\hline $11 / 18 / 2016$ & $4 / 9 / 2017$ & 0.2322 & Loess \\
\hline This Study & Min. & 0.0016 & Loess \\
\hline This Study & Mean & 0.0110 & Loess \\
\hline This study & Extreme & 0.2322 & Loess \\
\hline $\begin{array}{l}\text { Whipple et al } \\
2000\end{array}$ & $\begin{array}{l}\text { Mean } \\
\text { Max. }\end{array}$ & 0.0009 & $\begin{array}{c}\text { Highly } \\
\text { jointed/weak }\end{array}$ \\
\hline $\begin{array}{c}\text { Whipple et al } \\
2000 \\
\text { Stock and }\end{array}$ & $\begin{array}{l}\text { Mean } \\
\text { Min. }\end{array}$ & 0.00024 & $\begin{array}{l}\text { Resistant } \\
\text { rock }\end{array}$ \\
\hline $\begin{array}{c}\text { Montgomery, } \\
1999\end{array}$ & Min. & 0.0000004 & Granitoid \\
\hline $\begin{array}{c}\text { Stock and } \\
\text { Montgomery } \\
1999\end{array}$ & Max. & 0.007 & Mudstone \\
\hline $\begin{array}{c}\text { Kirby and } \\
\text { Whipple } 2001\end{array}$ & Mean. & 0.000432 & Sedimentary \\
\hline
\end{tabular}




\subsection{Discussion}

There are currently no independent estimates of erodibility for the study area. In order to determine if my calculated values were broadly consistent with other streams exhibiting common characteristics, I compiled K values from other studies for comparison. All of the following erodibility values use common $m$ and $n$ values of $m=0.4$ and $n=1$, standardized by Stock and Montgomery (1999), which allows for direct comparison. A study from Whipple et al. (2000) on bedrock incision of Alaska's Ukak River provides mean $\mathrm{K}$ values of $0.0009 \mathrm{~m}^{0.2} / \mathrm{yr}$ for highly jointed or weak rock and $0.00024 \mathrm{~m}^{0.2} / \mathrm{yr}$ for more resistant rock (Table 5.1). Stock and Montgomery (1999) report a range of K values from $0.0000004 \mathrm{~m}^{0.2} / \mathrm{yr}$ for granitoid substrate to $0.007 \mathrm{~m}^{0.2} / \mathrm{yr}$ for mudstone (Table 5.1)

An investigation using the stream power equation to quantify uplift rates from stream profiles by Kirby and Whipple (2001) provide additional erodibility values for comparison. That study found a mean value of $\mathrm{K}=0.000432 \mathrm{~m}^{0.2} / \mathrm{yr}$ for a variety of sedimentary rocks (Table 5.1).

The range of erodibilities determined in this study are comparable to, or up to an order of magnitude greater than, those of weak rock such as mudstone reported in previous studies. This implies the loess at the study area is highly erodible. Most detachment limited stream power studies have been performed using bedrock channels leading to lower erodibility values. Here the loess substrate behaves similarly to bedrock in a detachment limited fashion, but is significantly more erodible. The values of site specific erodibility found here may be capable of being applied to other basins with the same lithology, climate, and tectonism (Stock and Montgomery, 1999). 
Additional comparisons to the erodibility values calculated from jet test erosion studies (based on Eq. (5.1)) are possible, but these are typically reported in units on $\mathrm{m}^{3} / \mathrm{N}$ s. To convert the K values between these two, knowledge of site specific parameters such as channel roughness and scaling for channel geometry is required. An important note is that the $\mathrm{K}$ values based on the stream power equation capture the suite of physical processes that govern channel erosion including climate, hydrology, channel geometry, drainage basin properties, and substrate, while $\mathrm{K}$ values based on a shear strength equation directly capture the local physical soil parameters (Sklar and Dietrich, 1998; Clark and Wynn, 2006).

Systematically greater erodibility values were calculated during the longer intervals of the investigation. This is not meant to suggest that the properties of the substrate were changing through time, but are a product of the changing of input parameters to the stream power equation and to maintain the relationships of Equation 5.8 with a varying erosion rate and a relatively constant drainage area (Hancock et al., 1998). Longer time intervals during this study were associated with higher erosion rates (a direct input) and with higher discharges in the channel (indirect input). The use of drainage area as a proxy for discharge does not directly capture this. The upper channel has maintained a consistent width over the study period, so an increase in discharge results in an increase of water column depth. The deeper water column produces much greater shear stress on the channel bed (and the knickpoint lip/face) than a shallow, wide channel. 


\section{Discussion}

\subsection{Implications of Results}

"In the context of a river's whole life cycle a waterfall is momentary, occurring when a local disparity in bedrock erodibility between the down-stream section and up-stream section is present" (Davis, 1889).

In the case of Bull Mountain, the natural waterfalls of significant size correspond with knickpoints, and "momentary" means over a human time scale (years to decades). Here the knickpoint was probably initiated by an increase in discharge and not an erodibility disparity between the upper and lower stream section. The erosion rate of meters per year occurring at the Morningstar Creek knickpoint represents the disequilibrium in the landscape during this transient period. A combination of anthropomorphic influences, local geology, and climate has created a natural laboratory for this investigation.

Urbanization of the area surrounding the Morningstar Creek channel started in the 1980s, decades before this investigation took place. Over the study period the knickpoint retreated a minimum total of $14.83 \mathrm{~m}$ upstream. The exact timing of initiation of the knickpoint is unknown, but the extreme retreat rates discovered in the investigation suggest it could reach the top of the catchment in less than a few decades. The channel below the knickpoint is deeper and much wider (five times) than the upper channel, and the banks show signs of past disturbance and failure from instability. The channel narrows back to a width similar to the upper channel and features near-vertical stable banks farther downstream. The wider disturbed area of the channel between the knickpoint and the downstream point of narrowing may represent the path of retreat of the knickpoint and the extent and impact that this erosion had on the channel prior to this 
study. This indicates that the knickpoint did not initiate below the point where the channel re-narrows about 50 - $60 \mathrm{~m}$ downstream from its current location. The valley sides narrow around the channel in the upstream direction and as the proximity to infrastructure increases, which may increase the potential influence of urbanization in the watershed. The field observations, 3-D digital processing of point cloud data, and laboratory analysis provides insight on the following: how is the channel eroding (pattern, mechanisms, and rate); what is eroding (soil characterization); what may control the size and retreat mode of the knickpoint; and where do the inferred erodibility data fit into previous and future work on stream power based landscape evolution.

Recording the patterns and rates of erosion using TLS collection and point cloud analysis has provided a short term, detailed history of the erosion at the knickpoint in Morningstar Creek. At this scale, and for the discovery of the spatial variability of retreat, TLS provides invaluable information (Resop and Hession, 2010). However, this methodology and analysis is not void of complicating factors. As other TLS based erosion studies have noted, I too found that the high resolution nature of TLS collection results in very large data sets (a total of $\sim 24$ gigabytes) and computationally cumbersome operations, some steps taking tens of minutes processing time to complete (Kaiser et al., 2014). The nature of point cloud analysis relies on detecting changes relative to fixed reference features. However, in this study and in others, seasonal variation in vegetation, and the natural reference markers themselves, from scene to scene between intervals, caused them not to be truly fixed, directly affecting alignment (Day et al., 2013). This portion of the investigation has been highly iterative in nature; thus I developed a site 
specific baseline dataset and methodology simultaneously. In general, the MDD value on the fitness of the alignment, this study's measure of error between the ten interval pairs, was an order of magnitude less than the observed topographic changes to the knickpoint faces. Installing multiple fixed, man-made markers for the entire study period, rather than relying on natural markers, would have helped make this error of alignment consistent and may have systematically lowered it.

The four main patterns of erosion observed here -- exfoliation, block failure, plunge pool undercutting, and upper bank failure -- are consistent with other knickpoint erosion studies (Simon et al., 2000; Selander, 2004; Haviv et al., 2010). During most intervals, the net erosion observed was the product of all of these processes combined, but block failures and undercutting were responsible for the majority of the total erosion.

In the examination of hydrologic controls on the point cloud based erosion rates (excluding the extreme event), a significant linear correlation between total precipitation, average precipitation, and percentage of an interval during which over $0.015 \mathrm{~m}$ of precipitation occurred was revealed. To discover a significant correlation between average erosion rate and the precipitation metrics for data that include extreme erosion events, an alteration to methodology may be necessary. Having a larger data set, more interval pairs that include many extreme erosion events, and applying non-linear regressions may help to reveal a meaningful relationship. Increasing the frequency of TLS scans and a more site specific measure of precipitation would help the correlation of individual erosion events to individual storm events, and help to increase accuracy of both precipitation and erosion rates. 
The soil analysis portion of this investigation enabled a straightforward test of my hypothesis for mode of retreat and insights on control of the height of the Morningstar knickpoint. Initial observations of the knickpoint's shape, a vertical face joining the upper and lower channel reaches at a sharp angle, suggested the occurrence of a parallel retreat mode. This mode of retreat requires a distinct layering of resistant and non-resistant bed material (Gardner, 1983). I used dry bulk density as a proxy for relative resistance which revealed a distinct increase in measured bulk density at the top of the knickpoint/base of the upper channel $\left(1.85 \mathrm{~g} / \mathrm{cm}^{3}\right)$ relative to the center of the knickpoint face $\left(1.20 \mathrm{~g} / \mathrm{cm}^{3}\right)$ and the side walls of the upper channel $\left(1.46 \mathrm{~g} / \mathrm{cm}^{3}\right)$. I found a strong correlation between key dry bulk density measurements and shear strength, as measured by a Torvane device, suggesting that my choice of proxy was adequate. Additionally the TLS analysis confirmed that the knickpoint underwent only subtle changes to height or shape as it retreated up the channel over the study period. These three lines of evidence help confirm my hypothesis that this knickpoint is retreating in a parallel fashion. Even a small increase $\left(\sim 0.29 \mathrm{~g} / \mathrm{cm}^{3}\right)$ in relative density (or equivalently shear strength) of a thin horizon in the loess substrate can behave like a 'caprock'. This more resistant layer controls both the height of the knickpoint and the geometry of its face.

The classification of this dense layer as a fragipan was uncertain even though a distinct jump in density was found. Some of the other traditional fragipan characteristics, like a prismatic structure and minimum thickness of $15 \mathrm{~cm}$, were not observed (Smalley et al., 2015). To confidently call this layer a fragipans, further soil investigation must be done. Around the knickpoint face, the soil was sampled along a vertical transect 
specifically covering knickpoint features that define its geometry. The remaining sample locations were based on in situ observations of visually distinct features, like a failed, intact soil block or the base of the lower channel downstream. A completely predetermined sampling plan could allow for further soil density hypothesis testing and correlations in the future. The sampling devices were improvised, and while the diameter of the tube was controlled by the manufacturer, the length of each was not consistent. This may have introduced error into the volume calculations partially based on these dimensions. Additionally, field conditions and the nature of the soil made it difficult to remove soil plugs of a consistent amount. These systematic errors related to methodology may have contributed to error in absolute density, but relative density distinction was more important. Loess soils vary, even regionally, and further detailed analysis would be valuable for direct local comparisons (Lentz, 1977; Baumann, 2015). For example, larger soil samples ( $>50$ grams) should have been collected at each sample location to allow hydrometer grain size analysis on all samples.

The back calculated erodibility values are directly calculated from the erosion rates determined by the point cloud analysis using the stream power equation. This equation and calculations require the assumption of detachment limited channel conditions (Whipple and Tucker, 1999). The lack of sediment aggradation and the high rate of erosion support this assumption (Howard, 1994). During this short term study, large erosion amounts and retreat rates were observed and determined, leading to high erodibility values ranging from 0.0016 to $0.2332 \mathrm{~m}^{0.2} / \mathrm{yr}$. The set of site specific erodibility values for the Morningstar knickpoint are orders of magnitude higher than 
maximum values from some of the other studies examined, but comparable to those of weak bedrock. Detachment limited stream power based erosion studies typically examine or model channels with a more resistant bedrock substrate; here the channel is composed of weaker soil substrate (Sklar and Dietrich, 1998; Stock and Montgomery, 1999; Haviv et al., 2010). This may explain the large discrepancy among erodibility values. The stream power equation is very sensitive to the exponents $\mathrm{m}$ and $\mathrm{n}$. Setting $\mathrm{m}=0.4$, controlling the influence of drainage area, was chosen for ease of direct comparison. The drainage area term is a proxy for precipitation based discharge, so fine tuning this exponent may warrant further consideration. As discussed previously, the exact correlation between erosion and climate signals, like the retreat rate's relationship to precipitation, is unclear.

Even on the short time scale that this investigation took place, a wide range of erosion rates and erodibility values were observed. This, in part, represents the sensitivity of erosion at the knickpoint to variable precipitation and discharge. Using point cloud analysis has afforded me the opportunity to quantify the erosion at the knickpoint with a high level of resolution represented by an average point spacing of $5.3 \mathrm{~mm}$ at a distance of $10 \mathrm{~m}$ from the scanner. Examining the erosion rates from a stream power perspective has given me insight to the physical processes of erosion and the properties of the soil being incised (Stock and Montgomery, 1999). The task of scaling up these observations to longer term landscape evolution studies can be difficult (Whipple and Tucker, 1999). Although the knickpoint in this study is large, and the amount of erosion that took place is large, the landscape and geomorphic changes that occurred could not have been 
recorded with traditional airborne lidar, for which resolution is too coarse and the cost and time required for repeat measurements prohibitive. Long term landscape studies often use DEMs from airborne lidar scanning (ALS) as either an input to a numerical model or as the initial topographic conditions to examine a geomorphic processes, both in the channel and on the hillslope, beyond the boundaries of a single watershed (Dietrich et al., 2003). To analyze scalability of this study's erodibility results and insights into channel processes, it may be necessary to apply and test them in other regional watersheds at a range of scales with similar lithology and channel conditions. 


\section{Conclusions}

\subsection{Summary}

One of two known large knickpoints exists in the upper reach of the Morningstar Creek channel on the north side of Bull Mountain in the Tualatin River Basin. The channelized erosion occurring at this knickpoint was the subject of detailed observations and analysis on a range of scales, which has given insights into the physical processes shaping the local landscape.

TLS and point cloud analysis quantified erosion at the knickpoint, in three dimensions, throughout time over the course of roughly a year and a half. Measured erosion rates ranged from -0.23 to $-2.45 \mathrm{~m} / \mathrm{yr}$, with an average of $-1.52 \mathrm{~m} / \mathrm{yr}$, excluding an extreme erosion event that caused $12.5 \mathrm{~m}$ of erosion in $\sim 4.5$ months. That interval of extreme erosion event was recorded separately using traditional measurement techniques, and this resulted in an average rate of $-4.31 \mathrm{~m} / \mathrm{yr}$ if considered. This highlighted the importance of large, uncommon events in setting the pace of erosion. The point cloud processing techniques used visually highlighted four primary modes of erosion at the knickpoint face: exfoliation, large soil block failure, undercutting at the knickpoints base, and upper bank failure. The influence of three hydrologic metrics, cumulative precipitation, average precipitation rate, and percentage of daily precipitation events $\geq 0.015 \mathrm{~m}$, was established through a statistically significant relationships with point cloud based knickpoint retreat rates. Also, a strong, but not statistically significant, correlation between three observed exfoliation based erosion retreat rates and the number of wetting/drying cycles was determined. The relationship between extreme retreat rates 
and these hydrologic metrics was established to be not linearly significant and remains poorly understood.

Results from soil analysis indicate a layer of high bulk density $\left(1.85 \mathrm{~g} / \mathrm{cm}^{3}\right)$ loess at the base of the upper channel, while soils with lower bulk densities (1.204-1.575 $\mathrm{g} / \mathrm{cm}^{3}$ ) are above and below this horizon. This may restrict the channelized incision for that reach and control the height and geometry of the knickpoint face. This stratigraphic break and the observed erosion indicate a parallel retreat mode for the knickpoint.

In longer term landscape evolution studies, the erodibility value $\mathrm{K}$ is often unknown and estimated with either highly site specific jet tests or by fitting the stream power equation to an assumed steady-state river profile to facilitate calculating erosion rates. The novel approach presented in this study provides a suite of erodibility values based on erosion rates determined from TLS data. From the observed erosion rates and the assumption that the stream power equation adequately describes the erosion process, a site and substrate specific average value of erodibility $\left(\mathrm{K}=0.0110 \mathrm{~m}^{0.2} / \mathrm{yr}\right)$ was directly calculated. This value is comparable to landscape-scale estimates for mudstones and other weak rocks. This may be a helpful baseline parameter to apply to other channelized erosion sites in the region and a reference for longer term geomorphic studies.

The work presented here represents an innovative approach to quantifying erosion and erodibility in a channel. The field site provided a natural laboratory for detailed exploration of the physical processes occurring at a large knickpoint. The erosion in the channel at the knickpoint provides real-time feedback of the net effects of the urbanization of the watershed. The stream power law suggests any increase in discharge, 
anthropomorphic or natural, results in an increase in erosion rate. This study has shown that both of these parameters are quantifiable, and has revealed preliminary insights into their true relationship. Further exploration of the connection between discharge and erosion and the physical processes operating at the knickpoint is necessary if mitigation is required in the future. The erosion patterns revealed and measurements taken on this investigation's relatively short timescale stand alone to inform and enrich the existing erodibility metrics used in landscape evolution studies.

\subsection{Future Work and Management Implications}

Future research is needed to continue tracking the rapid erosion at the knickpoint and to gain further insights of the physical processes occurring. Recording additional extreme erosion events with point cloud technology would supplement the single extreme event measured in this study. A larger sample size of both extreme and moderate erosion events could help reveal the threshold behavior implied by this study's analysis. Measuring discharge in the channel at the knickpoint and establishing a rating curve with precipitation would be the best way to understand the relationship between discharge, precipitation intensity, and retreat rate. This would be a first step towards forecasting the erosion in the channel. While the frequency and intensity of precipitation cannot be controlled, it may be possible to dissipate the resulting discharge in the channel through infiltration ponds. Watershed managers should focus on the existing stormwater system of the surrounding neighborhood and determine a baseline of its contribution to channel 
erosion. Future stormwater management could work off this baseline and be tested against observed knickpoint retreat. 


\section{References}

Aksoy, H., and Kavvas, M.L., 2005, A review of hillslope and watershed scale erosion and sediment transport models: Catena, v. 64, p. 247-271, doi:

10.1016/j.catena.2005.08.008.

Allen, J.E., Burns, M., and Burns, S., 2009, Cataclysms on the Columbia: Portland, Ooligan Press, 208 p.

Assallay, a. M., Jefferson, I., Rogers, C.D.F., and Smalley, I.J., 1998, Fragipan formation in loess soils: Development of the Bryant hydroconsolidation hypothesis: Geoderma, v. 83, p. 1-16, doi: 10.1016/S0016-7061(97)00135-3.

Baumann, A.K., 2015, M.S. Thesis: Geostatistical examination of the geotechnical Portland BES databases with emphasis on silt: Portland State University, 42 p.

Birkeland, P.W., 1999, Soils and Geomorphology: New York, Oxford Universiy Press, $430 \mathrm{p}$.

Blakely, R.J., Beeson, M.H., Cruikshank, K., Wells, R.E., Johnson, A., and Walsh, K., 2004, Gravity study through the Tualatin Mountains, Oregon: Understanding crustal structure and earthquake hazards in the Portland urban area: Bulletin of the Seismological Society of America, v. 94, p. 1402-1409, doi: 10.1785/012003045.

Blakely, R.J., Wells, R.E., Yelin, T.S., Madin, I.P., and Beeson, M.H., 1995, Tectonic setting of the Portland-Vancouver area, Oregon and Washington: constraints from low-altitude aeromagnetic data: Geological Society of America Bulletin, v. 107, p. 1051-1062, doi: 10.1130/0016-7606(1995)107<1051:TSOTPV>2.3.CO;2.

Booth, D., and Henshaw, P.C., 2001, Rates of Channel Erosion in Small Urban Streams: Land Use and Watersheds: Human Influence on Hydrology and Geomorphology in Urban and Forest Areas, American Geophysical Union Monograph, v. 2, p. 17-38.

Bretz, J.H., 1969, The Lake Missoula Floods and the Channeled Scabland: The Journal of Geology, v. 77, p. 505-543.

Brown, M., and Lowe, D.G., 2005, Unsupervised 3D object recognition and reconstruction in unordered datasets: Proceedings of International Conference on 3D Digital Imaging and Modeling, 3DIM, p. 56-63, doi: 10.1109/3DIM.2005.81.

Brush, L.M., and Wolman, M.G., 1960, Knickpoint Behavior In Noncohesive Material: A Laboratory Study: Bulletin of the Geological Society of America, v. 71, p. 69-74. 
Chang, H., 2007, Comparative streamflow characterisitcs in urbanizing basins in the Portlant Metropolitan Area, Oregon, USA: Hydrological Processes, v. 21, p. 211222, doi: 10.1002/hyp.

Clark, L.A., and Wynn, T.M., 2006, Methods for determinining streambank critical shear stress and soil erodibility: Implication for erosion rate predictions: Transaction of the ASABE, v. 49, p. 1-12.

Cooley, S., 2016, Gis 4 Geomorphology: Watershed Delineation,.

Crosby, B.T., and Whipple, K.X., 2006, Knickpoint initiation and distribution within fluvial networks: 236 waterfalls in the Waipaoa River, North Island, New Zealand: Geomorphology, v. 82, p. 16-38, doi: 10.1016/j.geomorph.2005.08.023.

Davis, W.M., 1889, The rivers and valleys of Pennsylvannia: Cambridge, 81 p.

Day, S.S., Gran, K.B., Belmont, P., and Wawrzyniec, T., 2013, Measuring bluff erosion part 1: Terrestrial laser scanning methods for change detection: Earth Surface Processes and Landforms, v. 38, p. 1055-1067, doi: 10.1002/esp.3353.

Dietrich, W.E., Bellugi, D.G., Heimsath, A.M., Roering, J.J., Sklar, L.S., and Stock, J.D., 2003, Geomorphic transport laws for predicting landscape form and dynamics: Geophysical Monograph, v. 135, p. 1-30, doi: 10.1029/135GM09.

Duncan, R.A., 1982, A captured island chain in the Coast Range of Oregon and Washington: Journal of Geophysical Research, v. 87, p. 827-837.

England, P., and Wells, R.E., 1991, Neogene rotations and quasicontinous deformation of the Pacific Northwest continental margin.: Geology, v. 19, p. 978-981.

Evarts, R.C., O'Connor, J.E., Wells, R.E., and Madin, I.P., 2009, The Portland basin: A (big) river runs through it: GSA Today, v. 19, p. 4-10, doi: 10.1130/GSATG58A.1.

Feng, X., Wang, Y., Chen, L., Fu, B., and Bai, G., 2010, Modeling soil erosion and its response to land-use change in hilly catchments of the Chinese Loess Plateau: Geomorphology, v. 118, p. 239-248, doi: 10.1016/j.geomorph.2010.01.004.

Fu, B.-J., Wang, Y.-F., Lu, Y.-H., He, C.-S., Chen, L.-D., and Song, C.-J., 2009, The effects of land-use combinations on soil erosion: a case study in the Loess Plateau of China: Progress in Physical Geography, v. 33, p. 793-804, doi: $10.1177 / 0309133309350264$. 
Gardner, T.W., 1983, Experimental study of knickpoint and longitudinal profile evolution in cohesive, homogeneous material.: Geological Society of America Bulletin, v. 94, p. 664-572, doi: 10.1130/0016-7606(1983)94<664:ESOKAL>2.0.CO.

Gibbs, H.J., and Holland, W.Y., 1960, Petrographic and engineering properties of loess: Engineering Monograph, v. 28, doi: 10.2136/sssaj1961.03615995002500050007x.

Gilbert, G.K., 1877, Geology of the Henry Mountains:.

Gilbert, G.K., 1907, Rate of recession of Niagara Falls: Geological Society of America Bulletin, doi: 10.1086/278833.

Gilbert, G.K., 1909, The convexity of hilltops: The Journal of Geology, v. 17, p. 344350.

Green, G.L., 1982, Soil Survey of Washington County, Oregon:.

Hack, J.T., 1957, Studies of longitudinal wtream profiles in Virginia and Maryland: U.S. Geological Survey Professional Paper 294-B,.

Hancock, G.S., Anderson, R.S., and Whipple, K.X., 1998, Beyond power: Bedrock river incision process and form: Geophysical Monograph, v. 107, p. 35-60.

Hanson, G.J., and Hunt, S.L., 2007, Lessons learned using laboratory JET method to measure soil erodibility of compacted soils: Applied Engineering in Agriculture, v. 23, p. 305-312.

Hart, D.H., and Newcomb, R.C., 1965, Geology and ground water of the Tualatin Valley Oregon: U.S. Geological Survey Water-Supply Paper 1697, p. 183.

Haviv, I., Enzel, Y., Whipple, K.X., Zilberman, E., Matmon, a., Stone, J., and Fifield, K.L., 2010, Evolution of vertical knickpoints (waterfalls) with resistant caprock: Insights from numerical modeling: Journal of Geophysical Research: Earth Surface, v. 115, p. 1-22, doi: 10.1029/2008JF001187.

Hessel, R., and Van Asch, T., 2003, Modelling gully erosion for a small catchment on the Chinese Loess Plateau: Catena, v. 54, p. 131-146, doi: 10.1016/S03418162(03)00061-4.

Hessel, R., Messing, I., Liding, C., Ritsema, C., and Stolte, J., 2003, Soil erosion simulations of land use scenarios for a small Loess Plateau catchment: Catena, v. 54, p. 289-302, doi: 10.1016/S0341-8162(03)00070-5. 
Howard, A.D., 1994, A detachment limited model of drainage basin evolution: Water Resources Research, v. 30, p. 2261-2285, doi: 10.1029/94WR00757.

Howard, A.D., and Kerby, G., 1983, Channel changes in badlands: Geological Society of America Bulletin, v. 94, p. 739-752.

James, M.R., and Robson, S., 2012, Straightforward reconstruction of 3D surfaces and topography with a camera: Accuracy and geoscience application: Journal of Geophysical Research: Earth Surface, v. 117, p. 1-17, doi: 10.1029/2011JF002289.

Julien, P.Y., 2010, Erosion and Sedimentation: Cambridge, Cambridge University Press, $371 \mathrm{p}$.

Kaiser, A., Neugirg, F., Rock, G., Müller, C., Haas, F., Ries, J., and Schmidt, J., 2014, Small-scale surface reconstruction and volume calculation of soil erosion in complex Moroccan gully morphology using structure from motion: Remote Sensing, v. 6, p. 7050-7080, doi: 10.3390/rs6087050.

King, L.C., 1953, Canons of landscape evolution: Bulletin of the Geological Society of America, v. 64, p. 721-752, doi: 10.1130/0016-7606(1953)64[721:COLE]2.0.CO;2.

Kirby, E., and Whipple, K., 2001, Quantifying differential rock-uplift rates via stream profile analysis: Geology, v. 29, p. 415-418, doi: 10.1130/00917613(2001)029<0415:QDRURV>2.0.CO;2.

Kolbe, W., 1991, Darmok: Star Trek: The Next Generation, Season 5, Episode 2.

Laenen, A., 1983, Storm runoff as related to urbanization based on data collected in Salem and Portland, and generalized for the Willamette Valley, Oregon:.

Lane, E.W., 1953, Design of stable channels: American Soiciet of Civil Engineers Transactions, v. 120.

Lentz, R.T., 1977, M.S. Thesis: The petrology and stratigraphy of the Portland Hills Silt: Portland State University, 119 p.

Leopold, L., and Langbein, W., 1962, The concept of entropy in landscape evolution: U.S. Geol. Survey Prof., p. A1-A20, doi: 10.1080/01426399808706533.

Lindbo, D.L., Rhoton, F.E., Bigham, J.M., Hudnall, W.H., Jones, F.S., Smeck, N.E., and Tyler, D.D., 1994, Bulk Density and Fragipan Indentification in Loess Soils of the Lower Mississippi River Valley: Soil Science Society of America Journal, v. 58, p. 884-891. 
Lucieer, a., Jong, S.M.D., and Turner, D., 2014, Mapping landslide displacements using Structure from Motion (SfM) and image correlation of multi-temporal UAV photography: Progress in Physical Geography, v. 38, p. 97-116, doi: 10.1177/0309133313515293.

Marot, D., Regazzoni, P.-L., and Wahl, T., 2011, Energy-based method for providing soil surface erodibility rankings: Journal of Geotechnical and Geoenvironmental Engineering, v. 137, p. 1290-1293, doi: 10.1061/(ASCE)GT.1943-5606.0000538.

McNamara, J.P., Ziegler, A.D., Wood, S.H., and Vogler, J.B., 2006, Channel head locations with respect to geomorphologic thresholds derived from a digital elevation model: A case study in northern Thailand: Forest Ecology and Management, v. 224, p. 147-156, doi: 10.1016/j.foreco.2005.12.014.

McPhee, D.K., Langenheim, V.E., Wells, R.E., and Blakely, R.J., 2014, Tectonic evolution of the Tualatin Basin, northwest Oregon, as revealed by inversion of gravity data: Geosphere, v. 10, p. 264-275, doi: 10.1130/GES00929.1.

Montgomery, D.R., 1994, Road surface drainage, channel initiation, and slope instability: Water Resorces Research, v. 30, p. 1925-1932.

Montgomery, D.R., and Dietrich, W.E., 1994, Landscape Dissection and Drainage AreaSlope Thresholds, in Kirkby, M.J. ed., Process Models and Theoretical Geomorphology, Chichester, John Wiley \& Sons Ltd., p. 221-246.

Montgomery, D.R., and Foufoula-Georgiou, E., 1993, Channel network source representation using digital elevation models: Water Resources Research, v. 29, p. 3925-3934.

Muehlbauer, J.D., and Doyle, M.W., 2012, Knickpoint effects on macroinvertebrates, sediment, and discharge in urban and forested streams: urbanization outweighs microscale habitat heterogeneity: Freshwater Science, v. 31, p. 282-295, doi: 10.1899/11-010.1.

Olsen, M.J., Johnstone, E., Kuester, F., Driscoll, N., and Ashford, S. a., 2011, New automated point-cloud alignment for ground-based light detection and ranging data of long coastal sections: Journal of Surveying Engineering, v. 137, p. 14-25, doi: 10.1061/(ASCE)SU.1943-5428.0000030.

Pelletier, J., 2008, Quantitative Modeling of Earth Surface Processes: New York, Cambridge University Press.

Phillips, J.D., and Lutz, J.D., 2008, Profile convexities in bedrock and alluvial streams: Geomorphology, v. 102, p. 554-566, doi: 10.1016/j.geomorph.2008.05.042. 
Popowski, T.A., 1996, M.S. Thesis: Geology, structure, and tectonic history of the Tualatin Basin, northwestern Oregon: Oregon State University, 142 p.

Praskievicz, S., and Chang, H., 2011, Impacts of climate change and urban development on water resources in the Tualatin River Basin, Oregon: Annals of the Association of American Geographers, v. 101, p. 249-271, doi: 10.1080/00045608.2010.544934.

Resop, J.P., and Hession, W.C., 2010, Terrestrial laser scanning for monitoring streambank retreat: Comparison with traditional surveying techniques: Journal of Hydraulic Engineering, v. 136, p. 794-798, doi: 10.1061/(ASCE)HY.19437900.0000233.

Seidl, M., and Dietrich, W., 1992, The problem of channel erosion into bedrock: Catena, v. 23, p. 101-104.

Selander, J., 2004, M.S. Thesis: Processes of knickpoint propogation and bedrock incision in the Oregon Coast Range: University of Oregon, $51 \mathrm{p}$.

Selby, M.J., 2005, Hillslope Materials and Processes: New York, Oxford Universiy Press.

Shively, D.D., 1993, Landscape change in the Tualatin Basin following Euro-America settlement:.

Simon, A., Bennett, S., and Griffith, M.W., 2000, Knickpoint erosion and migration in cohesive streambeds, in Hotchkiss, R. and Glade, M. eds., Water Resource, ASCE, p. $1-9$.

Sklar, L., and Dietrich, W., 1998, River longitudinal profiles and bedrock incision models: Stream power and the influence of sediment supply, in Tinkler, K.J. and Wohl, E.E. eds., Rivers over rock: fluvial processes in bedrock channels, Wiley, p. 237-260.

Smalley, I.J., Bentley, S.P., and Markovic, S.B., 2015, Loess and fragipans: Development of polygonal-crack-network structures in fragipan horizons in loess ground: Quaternary International, p. 1-6, doi: 10.1016/j.quaint.2015.01.034.

Snavely, N., Seitz, S.M., and Szeliski, R., 2008, Modeling the world from Internet photo collections: International Journal of Computer Vision, v. 80, p. 189-210, doi: 10.1007/s11263-007-0107-3.

Stock, J.D., and Montgomery, D.R., 1999, Geologic constraints on bedrock river incision using the stream power law: Journal of Geophysical Research, v. 104, p. 4983, doi: 10.1029/98JB02139. 
Trimble, D.E., 1963, Geology of Portland, Oregon and adjacent areas: Geological Society of America Bulletin, v. 1119, p. 247.

Tucker, G.E., Lancaster, S.T., Gasparini, N.M., and Rafael, L., 2001, The ChannelHillslope Integrated Landscape Development Model ( CHILD ), in Harmon, R.S. and Doe III, W.W. eds., Landscape Erosion and Evolution Modeling, New York, Kluwer Academic/ Plenum Publishers, p. 349-388.

Waite, I.R., Sobieszczyk, S., Carpenter, K.D., Arnsberg, A.J., Johnson, H.M., Hughes, C.A., Sarantou, M.J., and Rinella, F.A., 2008, Effects of Urbanization on Stream Ecosystems in the Willamette River Basin and Surrounding Areas, Oregon and Washington:.

Wells, R.E., 1990, Paleomagnetic rotations and the Cenozoic tectonics of the Cascade arc, Washington, Oregon, and California: Journal of Geophysical Research: Solid Earth, v. 95, p. 19409-19417.

Whipple, K.X., Hancock, G.S., and Anderson, R.S., 2000, River incision into bedrock: Mechanics and relative efficacy of plucking, abrasion, and cavitation: Bulletin of the Geological Society of America, v. 112, p. 490-503, doi: 10.1130/00167606(2000)112<490:RIIBMA>2.0.CO.

Whipple, K.X., Snyder, N.P., and Dollenmayer, K., 2000, Rates and processes of bedrock incision by the Upper Ukak River since the 1912 Novarupta ash flow in the Valley of Ten Thousand Smokes, Alaska: Geology, v. 28, p. 835-838, doi: 10.1130/0091$7613(2000) 28<835$.

Whipple, K.X., and Tucker, G.E., 1999, Dynamics of the stream-power river incision model: Implications for height limits of mountain ranges, landscape response timescales, and research needs: Journal of Geophysical Research, v. 104, p. 661674.

Willgoose, G., Bras, R.L., and Rodriguez-iIturbe, I., 1991, A physical explanation of an observed link area-slope relationship: Water Resources Research, v. 27, p. 16971702, doi: 10.1029/91WR00937.

Wobus, C., Whipple, K.X., Kirby, E., Snyder, N., Johnson, J., Katerina, S., Crosby, B.T., and Sheehan, D., 2006, Tectonics from topography: Procedures, promise and pitfalls: Geological Society of America, v. 80301, doi: 10.1130/2006.2398(04).

Xinbao, Z., Higgitt, D.L., and Walling, D.E., 1990, A preliminary assessment of the potential for using caesium-137 to estimate rates of soil erosion in the Loess Plateau of China: Hydrological Sciences Journal, v. 35, p. 243-252, doi: $10.1080 / 02626669009492427$. 


\section{Appendix A: Additional Point Cloud Analysis Methodology}

The TLS device used was a Faro x330 tripod mounted scanner, specifications shown in Table A.1, allowing for millimeter scale resolution on merged scans from one time interval and centimeter precision when calculating the change between intervals. This scanner uses a single pulse return to measure millions of individual points on the surface of the knickpoint and produces a three - dimensional collection of points called a point cloud, similar to traditional airborne lidar.

Table A.1: TLS scanner details.

\begin{tabular}{ll}
\hline Make & Faro \\
Model & Focus $^{3 \mathrm{D}}$ X 330 \\
Range & $0.6 \mathrm{~m}$ to $330 \mathrm{~m}$ \\
Ranging Error & $\pm 2 \mathrm{~mm}$ \\
\hline
\end{tabular}

Point cloud processing and analysis was performed using Faro Scene (proprietary) and Cloud Compare (open source) software. Additionally, the scanner's built-in camera takes correlative photographs of the scanned surface so red/green/blue hue values (RGB) can be added to these points. Figure A.1 shows a visual comparison of what a point and shoot digital camera captures and a colorized point cloud with RGB values assigned. The laser scan requires line of sight to its intended target. During most intervals, multiple scans from different vantage points were recorded to capture both the knickpoint face and enough surrounding surfaces for aligning overlapping scans based on stable ground that did not change from one scene to the next. The specific scanner parameters and collection information for each data set is shown in Table A.2. The average number of points was about 14 million per interval. The landscape was changing throughout the study and as a 
result, the reference points, natural benchmarks such as trees used for later alignment, varied. The five intervals where point cloud data were collected over 14 months with an average of 15 weeks between scans.
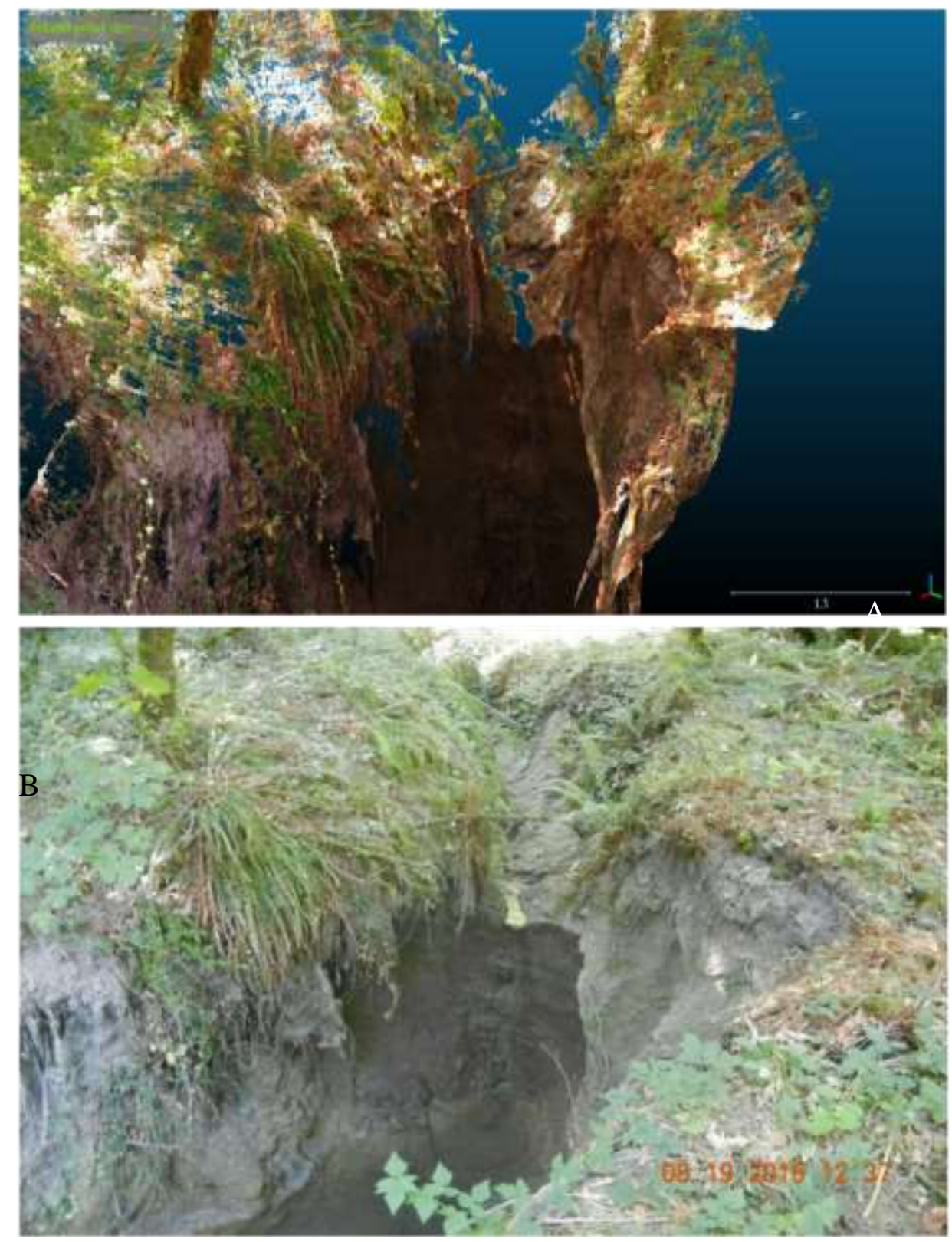

Figure A.1: A visual comparison of a colorized point cloud (A) and a digital photograph (B). The point cloud and photograph were collected at the same place and at the same time $(8 / 19 / 2015)$. 


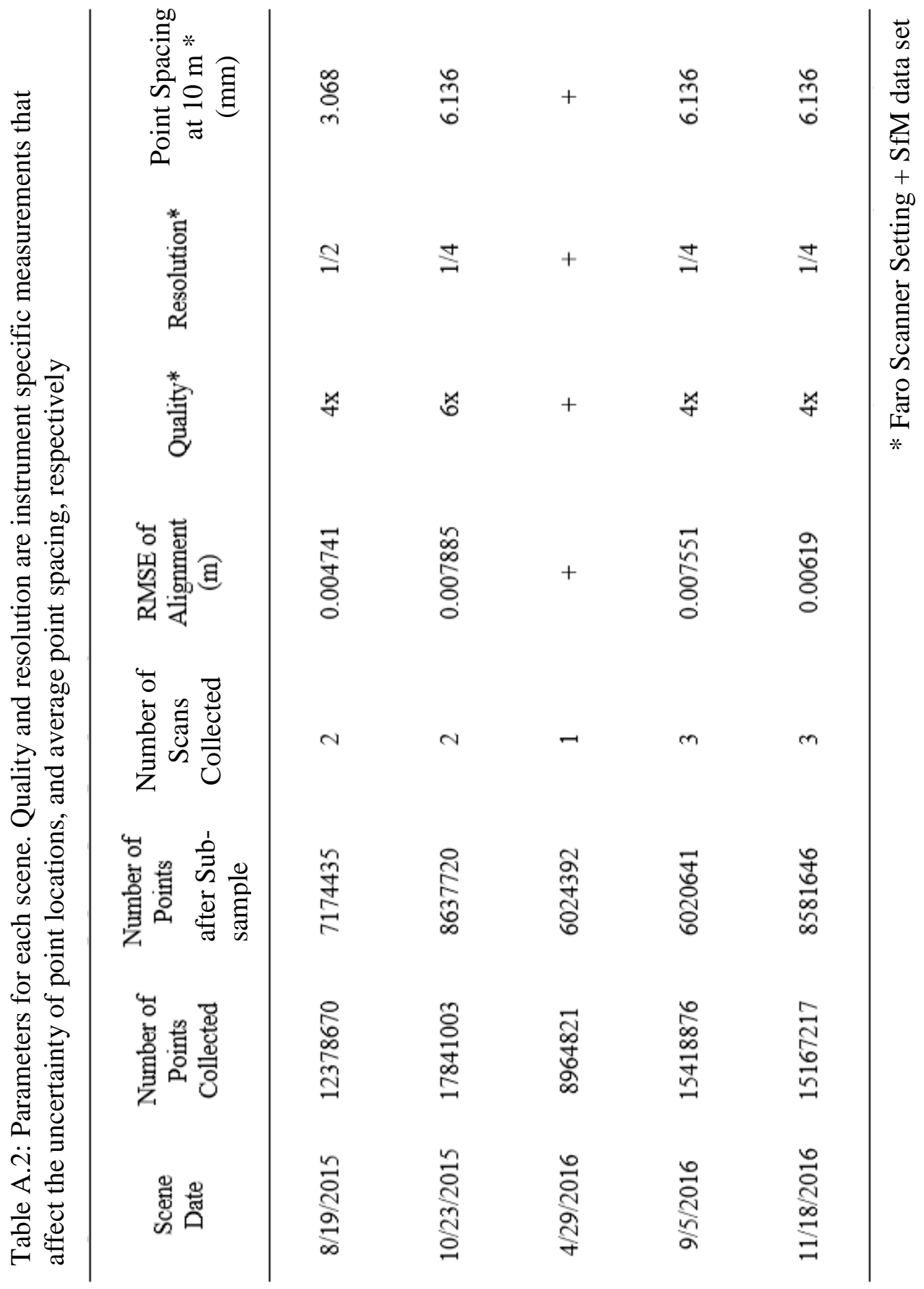


To evaluate the performance of an emerging technique known as Structure from Motion (SfM) for generating 3-D point clouds, the point cloud from the 4/29/2015 time interval was not collected using the Faro scanner. Instead, a set of 421 digital photos were taken of the knickpoint at this time. The photographs feature the knickpoint and surrounding reference targets from a range of angles and distances. The 3D geometry of the knickpoint featured in this photoset was reconstructed through a photogrammetric process (Snavely et al., 2008). The same objects and features amongs the individual photographs were detected and matched, and these common 3D points created the topographic surface model (Brown and Lowe, 2005). Like TLS, SfM has been used for previous geomorphic studies to quantify surface changes in high resolution, with precision that was comparable to TLS (James and Robson, 2012; Lucieer et al., 2014). These photos were processed using Agisoft PhotoScan Professional trial software, which automates the unsupervised reconstruction of the images to create a dense point cloud.

For TLS surveys, the individual scans for each date were merged using a two-step alignment process to create a scene. Since the scans captured overlapping areas, I first visually aligned them through a series of rigid body rotations and translations, using robust reference markers like tree trunks that appeared in overlapping parts of both scans. I then segmented a small specific area of each scan to isolate stable reference marker by eliminating surrounding unstable vegetation. Next I used an automated tool called fine registration with iterative closest point (ICP) on the segmented parts of the scans, which processes the overlapping clouds through point registration until the root mean square error (RMSE) of the difference between each point in one cloud reaches a small, user 
defined threshold. In point cloud analysis, the RMSE is the average distance between each point in one scan and the nearest point in the second scan (or one from each scene), and is an estimate of the uncertainty of the position of each point in the cloud. This fine registration takes two scans that are out of alignment, finds a point from one data set with the smallest Euclidian distance from its pair point in the other data set, and iteratively determines the combination of rotations and translations that minimizes the RMSE. The translation and rotation parameters of the roto-translation matrix define how the $\mathrm{x}, \mathrm{y}$, and $\mathrm{z}$ components of the segment scan (a subset of a scan) were altered to fit a different scan. This workflow, a graphical representation of which is shown in Figure A.2, consists of collection, merging, and alignment of each scene, then alignment of each interval pair of scenes. For example, a typical workflow would be as follows:

1) On $9 / 5 / 2016$ I collected 3 scans (scan A, B, and C) of the knickpoint on Morningstar Creek to capture the entire topography of the area.

2) I selected scan A as the reference scan, then manually translated and rotated scans B and C to approximately align them with scan A

3) A portion of a tree trunk that appeared in both scan A and B was subsampled creating a segment. The segmented tree trunks from scan A and B were selected by themselves and aligned using the ICP algorithm. The segment from scan A was selected as the model (fixed) and the segment from scan B was selected as the data (shifted). ICP alignment gives the roto-translation matrix that minimizes the misfit between segments from scans A and B. 
4) This transformation matrix was applied to the remaining, non-segmented part of scan B, transforming the rest of scan B into the same alignment with scan A as the tree trunk segments.

5) Scan A and B are now aligned and the merge tool was used to combine them into one scene.

6) Steps 3 - 5 were repeated with the merged cloud A and B, and scan C.

These steps were applied to data sets that contained multiple scans for their interval. The alignment RMSE values for aligning individual scans averaged $0.07 \mathrm{~m}$, the number of scans for each interval scene ranged from 2 - 3 scans, and the average number of points per scene was 13,954,117 (Table A.2). 

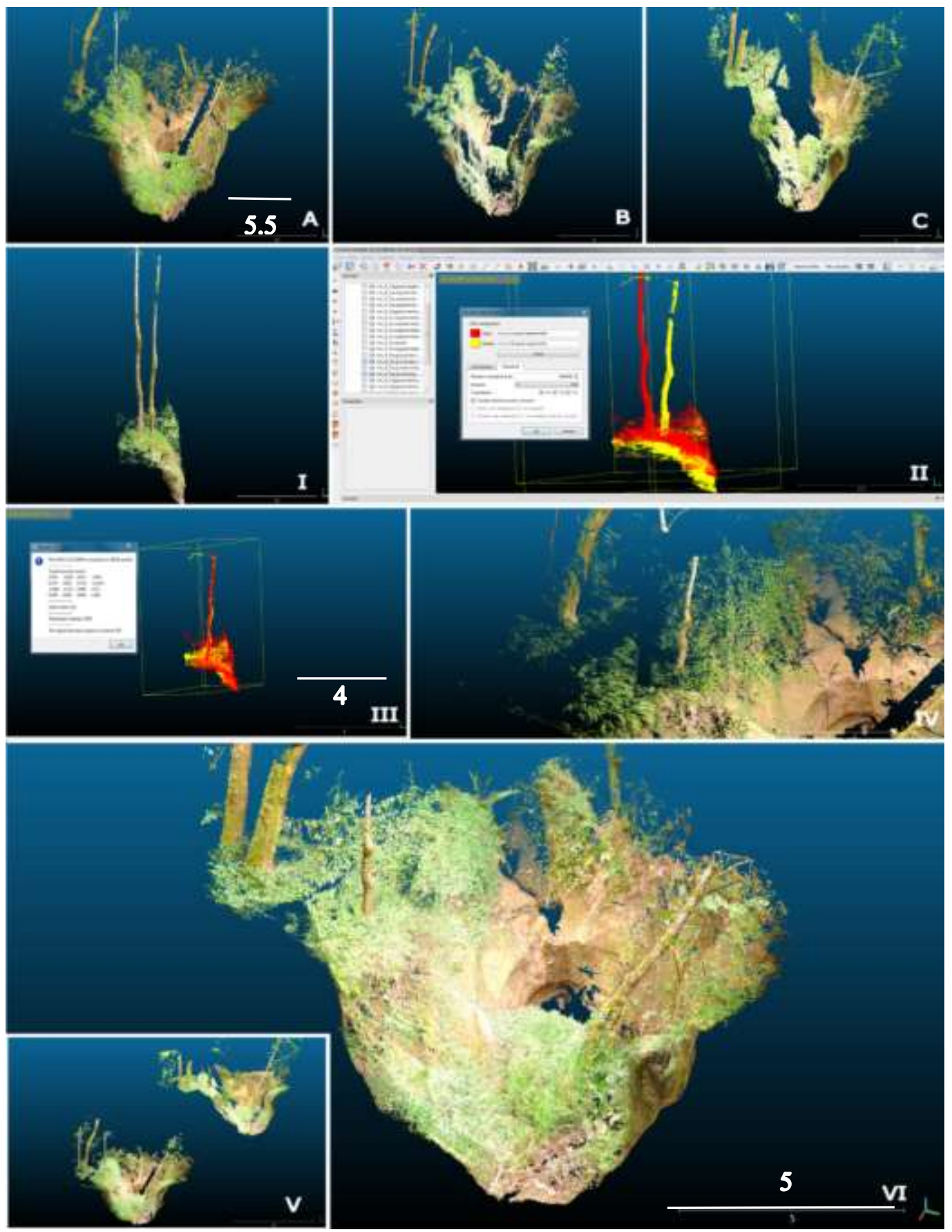

Figure A.2: A graphical flow chart showing the methodology during the processing and analysis of the knickpoint point clouds. Scans A, B and C were taken from different viewpoints on 9/5/2016. (I) Shows the tree trunk reference point in both scans A and B. (II) Shows the mismatch. (III) Shows the aligned tree trunk. (IV) Shows the shifted tree trunk segment in relation to the remaining parts of scan A. (V) Shows the completed aligned scans A and B and Scan C which has not been aligned. (VI ) Shows the final scene, composed of the alignment of scans A, B and C. All scale bars are in meters 
After the point clouds were aligned and merged into a scene for each interval, I subsampled the scene randomly down to about half the number of points (Table A.2). This was done to reduce redundant point coverage and increase computation speed in later analysis. These five scenes yielded ten interval pairs, each interval pair containing two point cloud scenes from the collection dates. The before and after scenes were aligned to each other, using the same alignment procedure discussed above. A record of the RMSE of alignment for each interval pair was on average 2.5 times greater than the RMSE from aligning scans from the same date. This larger RMSE is used to calculate the lower limit for the detectable change as described in the following paragraphs. RMSE values of alignment show a range on the interval pairs of 0.003 to $0.057 \mathrm{~m}$, with an average of $0.02 \mathrm{~m}$ (Table A.3).

To focus on quantifying the erosion and retreat rate at the knickpoint face, I selected and separated overlapping portions of both knickpoint faces from the aligned interval pairs. I then applied a $90^{\circ}$ rotation about the y-axis so that the surface normal to the knickpoint face pointed up in the z-direction. This enables the calculation of volume by subtracting the two surfaces in the z-direction. Due to the concave geometric nature of the knickpoint faces, calculating distance and surface area along the $\mathrm{z}$ axis after the $90^{\circ}$ rotation reduced edge effects. I maintained the alignment of the faces for each interval pair by reorienting them in unison. A series of images (Fig. A.3) shows an aligned interval pair, the corresponding selection and separation of their knickpoint faces, and their rotation to horizontal, as described below. 

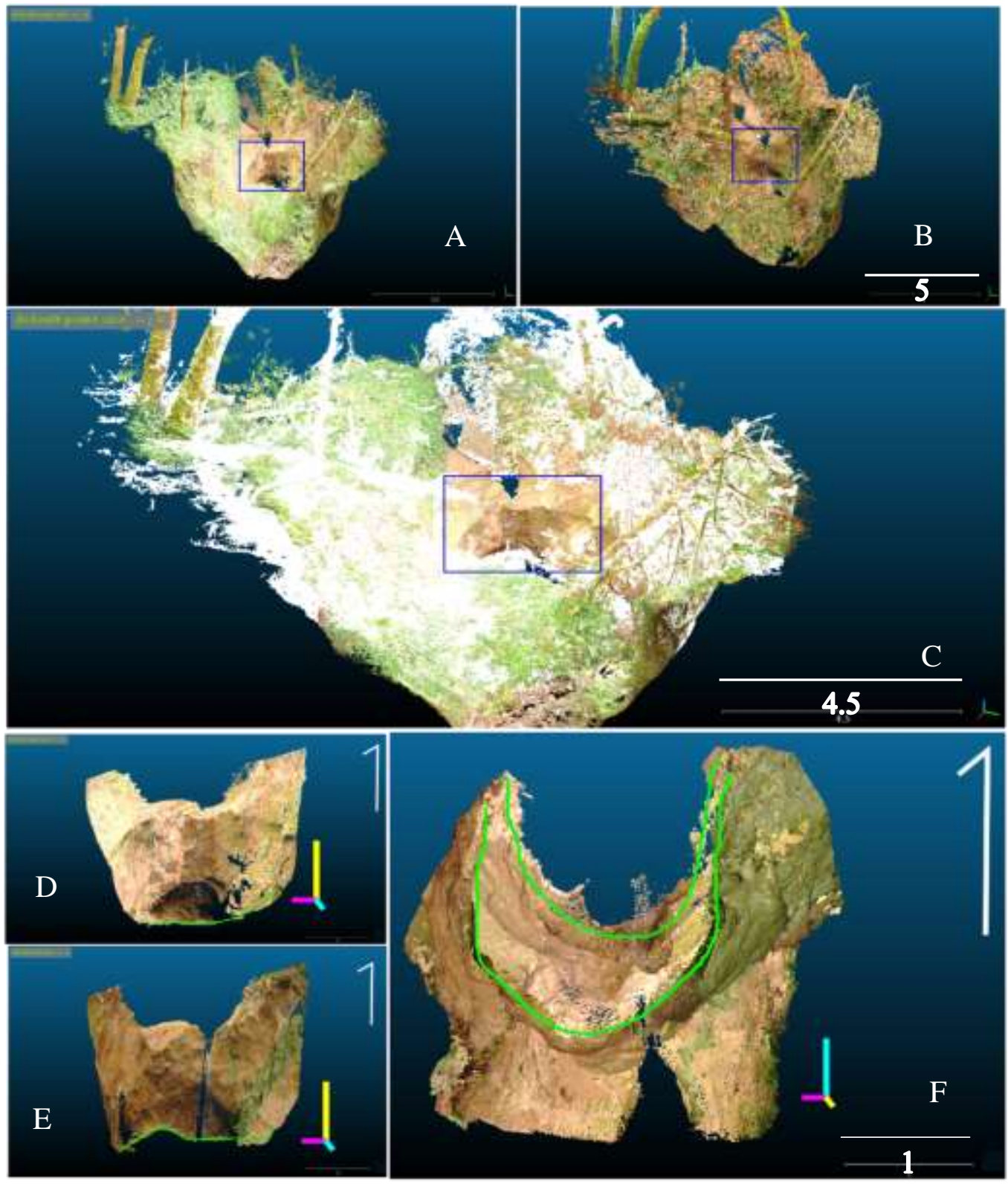

Figure A.3: This series of images graphically shows the step by step methodology of preparing the interval point clouds for volume calculation. The upper most panels (A) and (B) show the two point cloud of the interval pair with a blue square outlining the knickpoint face. The middle panel (C), shows the aligned interval pair with the faces highlighted with a blue square. The left lower panels (D) and (E), show subsampled faces of the interval pair, the green line outlines the base of the knickpoint. The white arrow indicates the data frames $\mathrm{z}$ axis while the magenta/yellow/cyan trident indicates the relative orientation of the faces. The right lower panel (F), shows the rotation of the aligned faces 90 degrees about the y-axis, so that the knickpoint face is orthogonal the relative to the new $\mathrm{z}$ axis, the green lines indicate the location of the knickpoint face's base. All scale bars are in meters 
Table A.3: The before and after dates, average amount of retreat, the RMSE of alignment and the percentage of matching cells for the volume analysis for each interval pair.

\begin{tabular}{|c|c|c|c|c|}
\hline Scene 1 & Scene 2 & $\begin{array}{l}\text { Amount } \\
\text { of } \\
\text { Upstream } \\
\text { Retreat } \\
\text { (m) }\end{array}$ & $\begin{array}{c}\text { RMSE } \\
\text { of } \\
\text { Alignment } \\
\text { (m) }\end{array}$ & $\begin{array}{l}\text { Fraction } \\
\text { of } \\
\text { Matching } \\
\text { Cells }\end{array}$ \\
\hline $8 / 19 / 2015$ & $10 / 23 / 2015$ & 0.040 & 0.00410 & 0.956 \\
\hline $8 / 19 / 2015$ & $4 / 29 / 2016$ & 1.354 & 0.01491 & 0.951 \\
\hline $8 / 19 / 2015$ & $9 / 5 / 2016$ & 1.534 & 0.00424 & 0.95 \\
\hline $8 / 19 / 2015$ & $11 / 18 / 2016$ & 2.330 & 0.05706 & 0.951 \\
\hline $10 / 23 / 2015$ & $4 / 29 / 2016$ & 1.271 & 0.03192 & 0.903 \\
\hline $10 / 23 / 2015$ & $9 / 5 / 2016$ & 1.436 & 0.01386 & 0.93 \\
\hline $10 / 23 / 2015$ & $11 / 18 / 2016$ & 2.200 & 0.01513 & 0.94 \\
\hline $4 / 29 / 2016$ & $9 / 5 / 2016$ & 0.174 & 0.01376 & 0.94 \\
\hline $4 / 29 / 2016$ & $11 / 18 / 2016$ & 0.586 & 0.01443 & 0.994 \\
\hline $9 / 5 / 2016$ & $11 / 18 / 2016$ & 0.420 & 0.00320 & 0.968 \\
\hline
\end{tabular}


The volume difference between knickpoint faces for each interval pair was calculated as follows: Each point cloud was rasterized to create two gridded surfaces, with grid spacing of $0.001 \mathrm{~m}$ to ensure the highest number of matching cells. Empty cells (those with no data points) were filled using nearest-neighbor interpolation with values from neighboring points. The grid from the later knickpoint face (the more recent collection date data set) wassubtracted from the grid of the previous knickpoint face (earlier collection date data set). The total dimensions of the grid varied, but were typically $2.612 \mathrm{~m} \times 1.915 \mathrm{~m}$, based on the average point densities of individual scenes. Volume change was then calculated by multiplying the average elevation change of each cell by the area of each cell and summing over the entire surface of the knickpoint face. Eroded volume, the number of matching cells, and the surface areas over which volume was calculated are summarized in Table A.3. These values were directly used to calculate retreat rate, normalizing the volume difference by surface area and dividing by the amount of time for each interval pair. Additionally, to visualize the spatial pattern of volume changes, I produced a choropleth (where different volumes correspond to correlated intensity color scale) of the volume change per cell between the gridded faces.

I completed a cloud to cloud distance analysis for an alternative representation of the changes between interval pairs that did not involve gridding or interpolation. The high density of the point clouds allows the determination of the point-to-point distances between each point in the $2^{\text {nd }}$ data set and its closest neighboring point in the $1^{\text {st }}$ data set for each of the interval pairs. The results of this analysis can be visualized by coloring the $2^{\text {nd }}$ point cloud according to the calculated distance and producing a map of the 
topographic changes. This color ramp corresponds to the range of calculated point-topoint distances in meters. The minimum detectable difference (MDD) is based on the RMSE of alignment of two scenes as described below, and areas where the distance between points is less than the MDD are visually grayed out.

Total error, or equivalently the MDD, was computed using a standard Gaussian error propagation, such that,

$$
E r=\sqrt{(a)^{2}+(b)^{2}}
$$

(Olsen et al., 2011), where the variables a and b are the individual RMSE of each scan or scene, and Er is the total error when scans are combined into a scene or two scenes are differenced.

This combines the RMSE values for the alignment of the individual members of the interval pair and the RMSE of alignment for the interval pair together. The total error (Er) incorporates the uncertainty associated with point cloud collection, alignment, and differencing. 


\section{Appendix B: Additional Point Cloud Differencing Analysis and Figures}

The visual pattern of erosion based on point to point distance between 8/19/2015 and 4/29/2016 is shown in Figure B.1A. The areas of yellow to yellow-green indicate areas where a difference of $\sim 0.75$ to $1.28 \mathrm{~m}$ was measured, which exceeds the MDD of $0.02 \mathrm{~m}$. The modes of erosion here are attributed to a combination of exfoliation and block failure integrated across the upper portion of the face. The areas of orange and red near the base correspond to longer distances, between $1.54 \mathrm{~m}$ and $1.8 \mathrm{~m}$. This area is attributed to undercutting erosion at the rear of the plunge pool. Figure B.1B showing the change in volume per cell confirms these observations. Areas of largest measured upstream retreat, shown in blue, spatially overlap with the erosion due to undercutting. Total volume of erosion was $-5.14 \mathrm{~m}^{3}$ across the $3.8 \mathrm{~m}^{2}$ surface area of the face (Table 3.1). The amount of upstream retreat for this period was $-1.354 \mathrm{~m}$. 


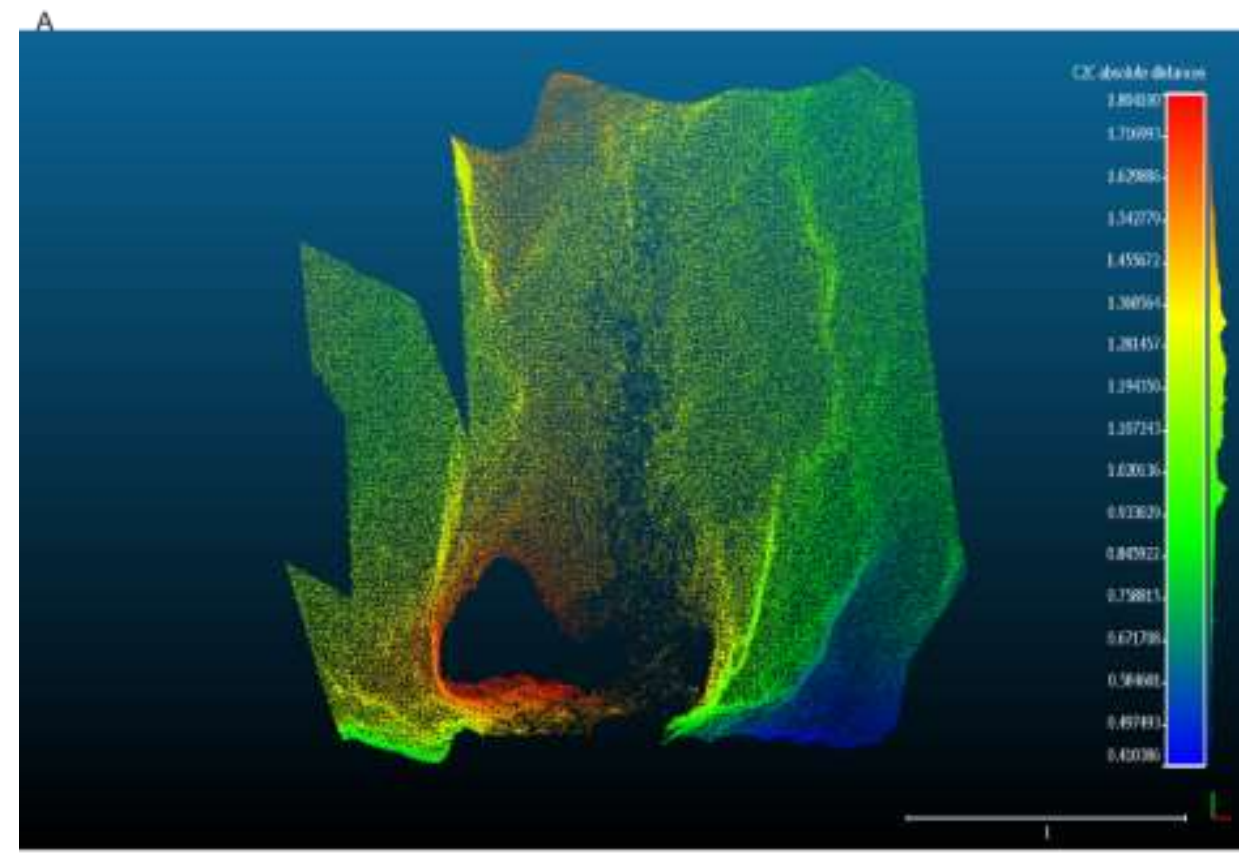

B

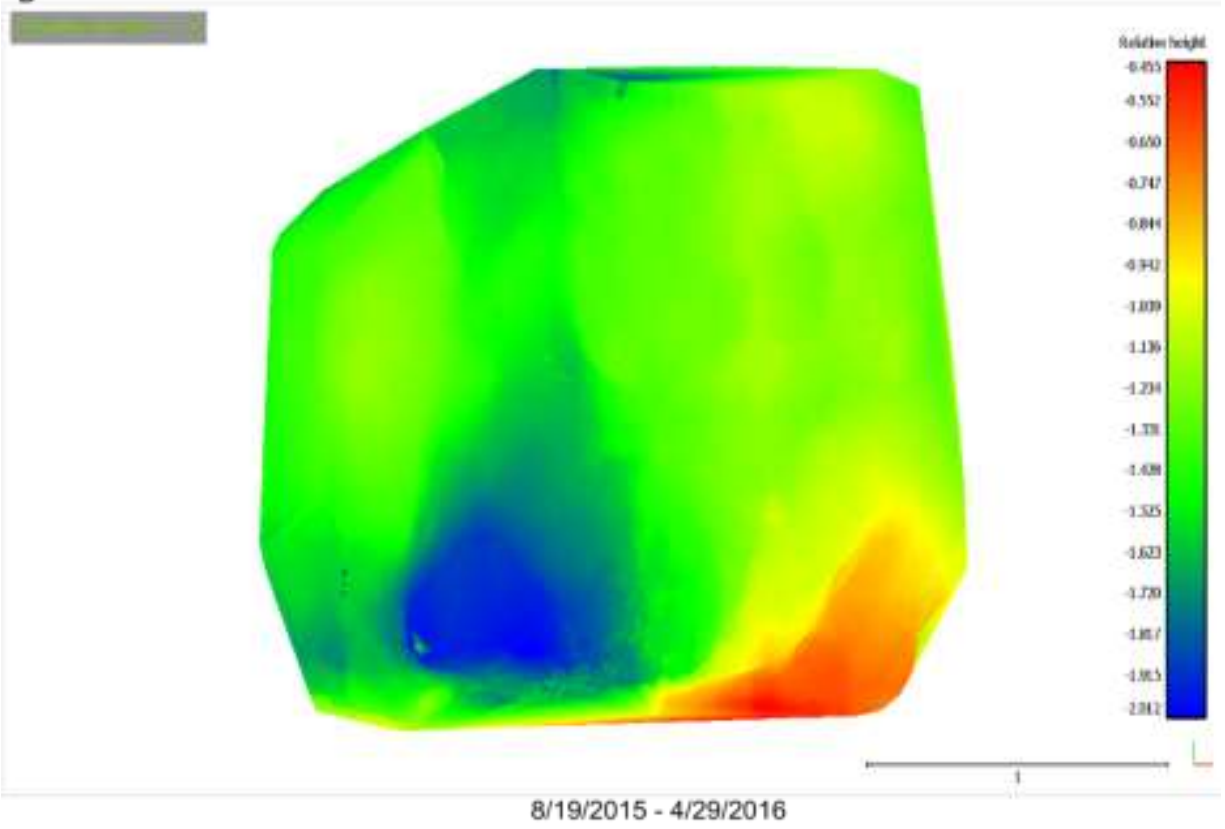

Figure B.1: (A) Shows the pattern and distribution of minimum point to point distances between the knickpoint face on 8/19/2015 and 4/29/2016. (B) Shows a choropleth map of the change in horizontal distance of the knickpoint face between 8/19/2015 and 4/29/2016. All scales are in meters. 
Figure B.2A shows the change detected between 4/29/2015 and 11/18/2016 based on point to point based distance measurements. The left and right flanks, areas of blue, underwent the least amount of retreat, $0.058 \mathrm{~m}$, which exceeds the MDD of $0.02 \mathrm{~m}$. The highest distance measurements, areas of red and orange, occurred on points in the center of the face, $0.69 \mathrm{~m}$ to $0.923 \mathrm{~m}$. Undercutting is primary type of erosion occurring here while a combination of exfoliation and block failure erosion occurred across the face. The pattern of erosion based on the measured volume of erosion over this interval is shown in Figure B.2B. The left side of the undercut cave shows the highest relative height change, $1.47 \mathrm{~m}$. Total volume of erosion was $-2.84 \mathrm{~m}^{3}$ across the $4.85 \mathrm{~m}^{2}$ surface area of the face (Table 3.1). The amount of upstream retreat for this period was $-0.59 \mathrm{~m}$. 

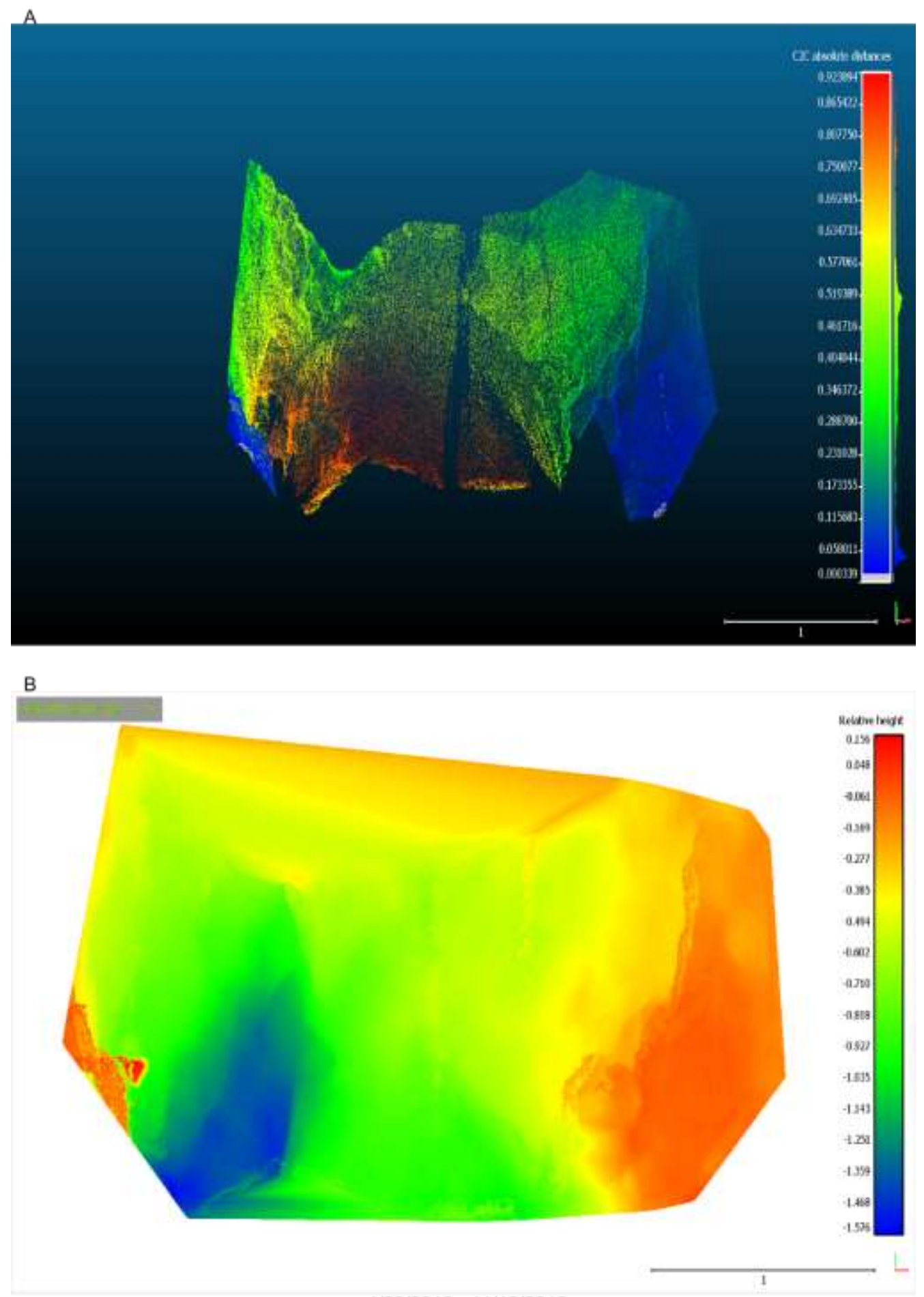

$4 / 29 / 2016-11 / 18 / 2016$

Figure B.2: (A) Shows the pattern and distribution of minimum point to point distances between the knickpoint face on 4/29/2016 and 11/18/2016. (B) Shows a choropleth map of the change in horizontal distance of the knickpoint face between 4/29/2016 and 11/18/2016. All scales are in meters. 
The visual pattern of erosion based on point to point distance between 8/19/2015 and 9/5/2016 is shown in Figure B.3A. The distribution of distance measurements behaves in a bimodal fashion. One grouping, areas of green to yellow, indicate a difference of $\sim 1.14 \mathrm{~m}$ while the other peak is centered on $1.51 \mathrm{~m}$, areas of yellow to orange, both of which exceeds the MDD of $0.99 \mathrm{~cm}$. The change in time for this interval pair is over one year, and the erosion observed is a result of all three modes. The map showing the pattern of volume per cell change (Fig. B.3B) highlights how the undercutting (blue) has extended laterally when compared to the previous interval pair. These zone of blue corresponds with the largest changes in height, between 2.11 and 2.31 m. Total volume of erosion was $-4.68 \mathrm{~m}^{3}$ across the $3.05 \mathrm{~m}^{2}$ surface area of the face (Table 3.1). The amount of upstream retreat for this period was $-1.53 \mathrm{~m}$. 


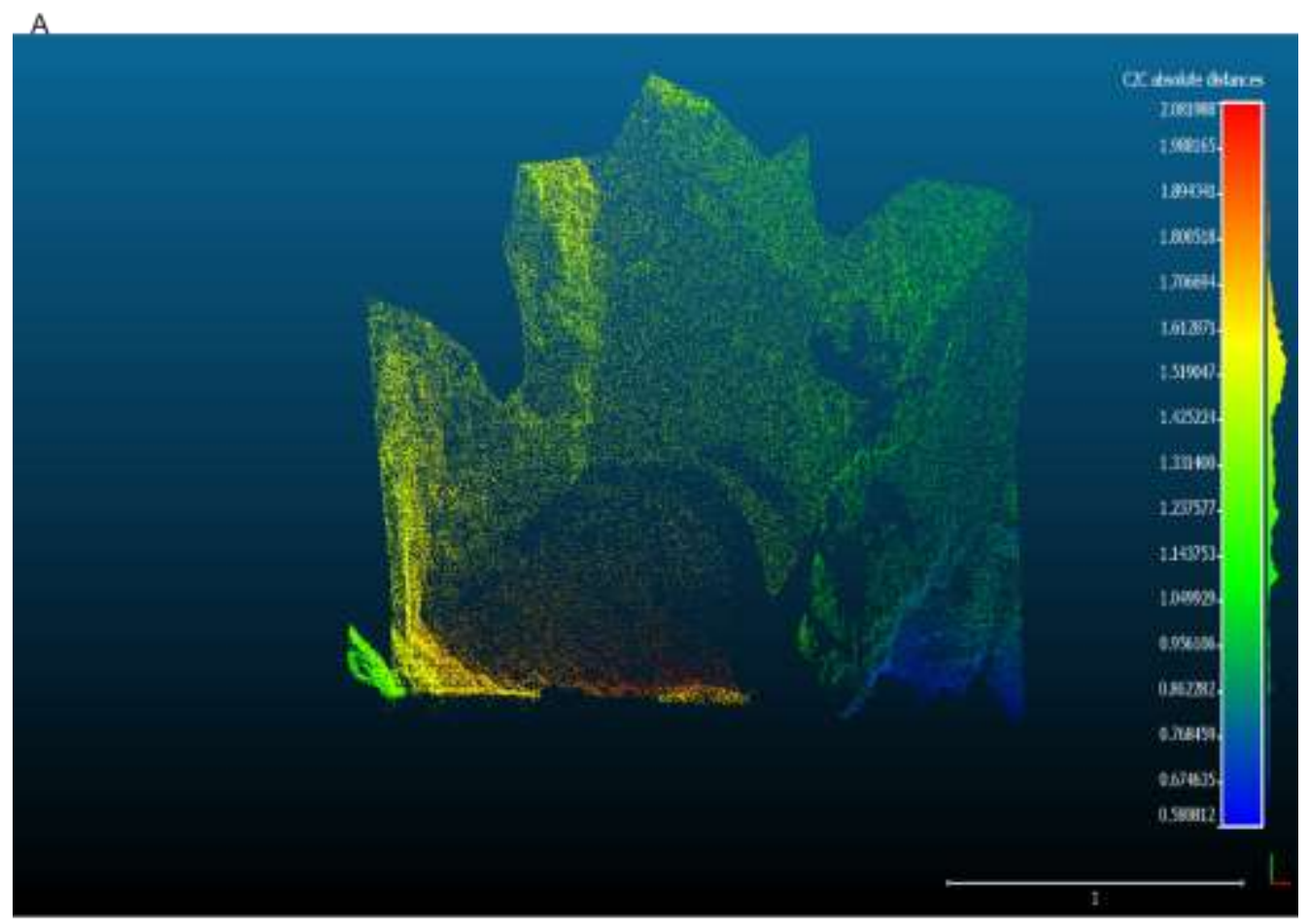

B

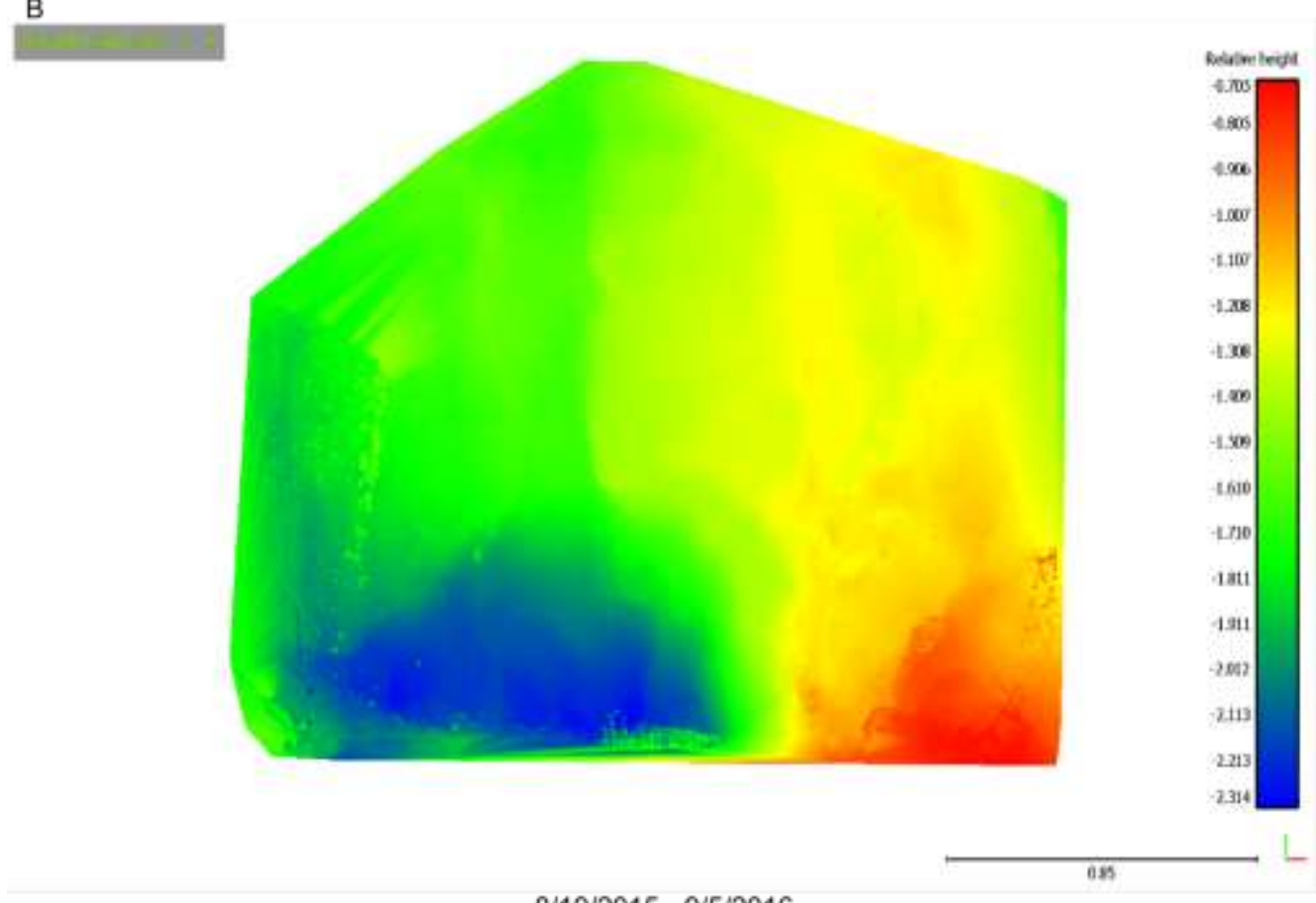

$8 / 19 / 2015-9 / 5 / 2016$

Figure B.3: (A) Shows the pattern and distribution of minimum point to point distances between the knickpoint face on 8/19/2015 and 9/5/2016. (B) Shows a choropleth map of the change in horizontal distance of the knickpoint face between 8/19/2015 and 9/5/2016. All scales are in meters. 
The pattern of erosion in Figure B.4A shows the point to point distance map between scans on 10/23/2015 and 9/5/2016. The areas of the knickpoint face that are green and blue correspond to smaller measured change in distance, centered around 0.99 $\mathrm{m}$. The larger distances of $1.452 \mathrm{~m}$ to $1.99 \mathrm{~m}$ between points is seen around the base on the left side, yellow to red, which exceeds the MDD of $0.02 \mathrm{~m}$. This is where undercutting is occurring. The map of the change in volume per cell, Figure B.4B, highlights the increase in measured erosion from right to left. The right half of the face, orange to red, underwent 0.69 to $1.38 \mathrm{~m}$ of erosion. The left portion of the face, green to blue, underwent 2.22 to $2.92 \mathrm{~m}$. The total volume of erosion was $-4.86 \mathrm{~m}^{3}$ across the $3.49 \mathrm{~m}^{2}$ surface area of the face (Table 3.1). The amount of upstream retreat for this period was $-1.4 \mathrm{~m}$. 


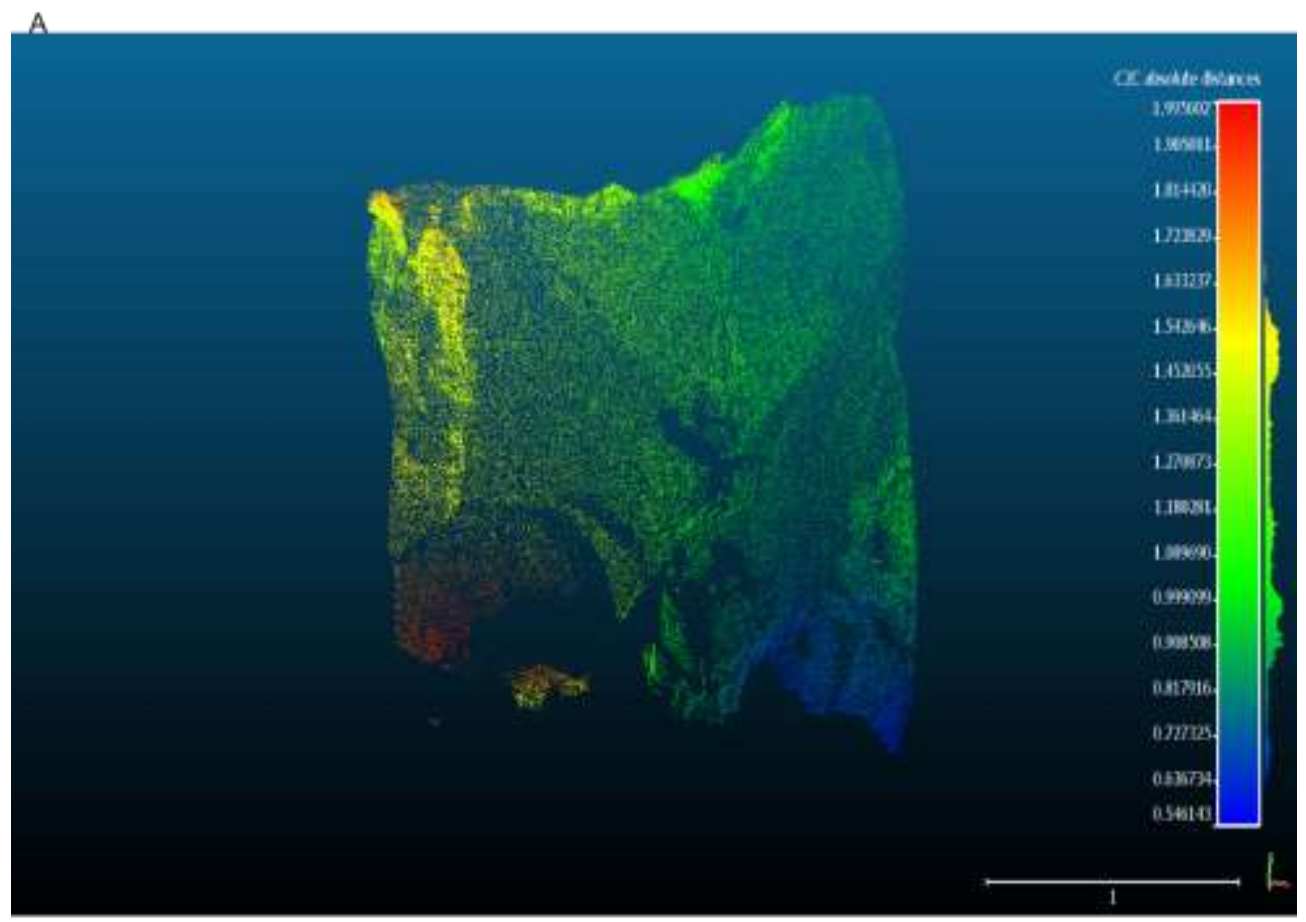

B

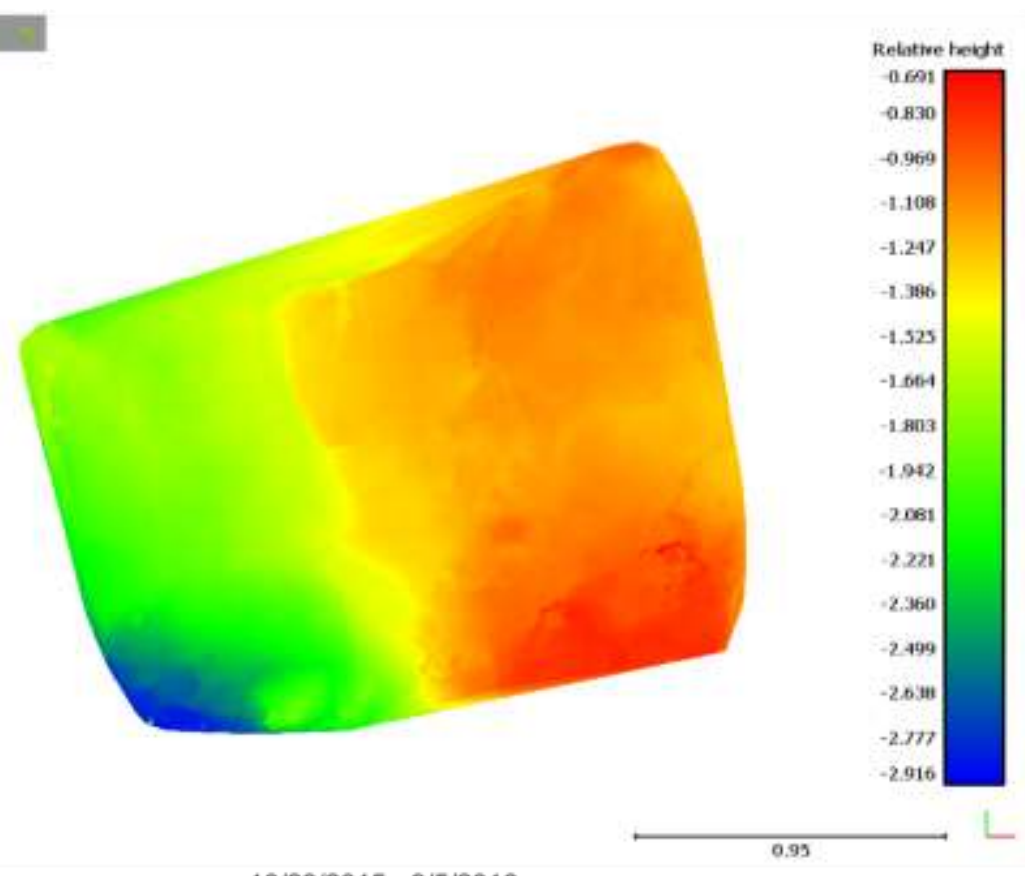

$10 / 23 / 2015-9 / 5 / 2016$

Figure B.4: (A) Shows the pattern and distribution of minimum point to point distances between the knickpoint face on 10/23/2015 and 9/5/2016. (B) Shows a choropleth map of the change in horizontal distance of the knickpoint face between 10/23/2015 and 9/5/2016. All scales are in meters. 
Figure B.5A shows the pattern of erosion based on point to point distances measured between 10/23/2015 and 11/18/2016. The distribution of measured distances appears to be uniform. The smallest distances between point clouds was measure on the right side near the base (blue) while the largest change in distance occurred on the left side near the base (red). A combination of exfoliation and block failure erosion occurred over this interval across the knickpoint face; however the largest erosion occurred in an area associated with undercutting. The pattern of measured volumetric change is shown in Figure B.5B. The knob of erosion resistance is highlighted in red to orange with less than $-1.49 \mathrm{~m}$ of height change, which exceeds the MDD of $0.02 \mathrm{~m}$. The blue areas indicate the largest difference in relative height of -3.10 to $-3.42 \mathrm{~m}$. Total volume of erosion was - $6.06 \mathrm{~m}^{3}$ across the $2.75 \mathrm{~m}^{2}$ surface area of the face (Table 3.1). The amount of upstream retreat for this period was $-2.20 \mathrm{~m}$. 


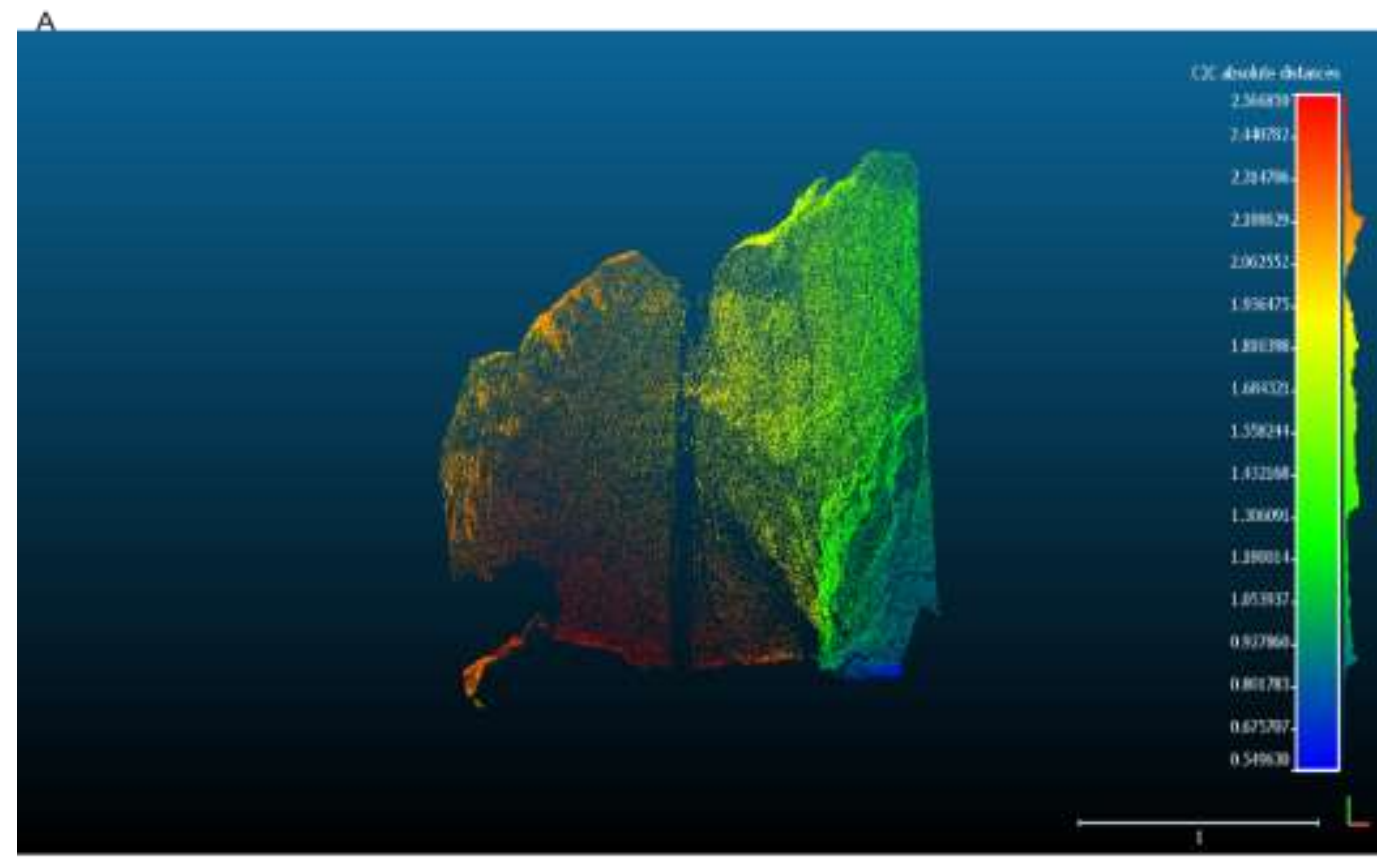

B

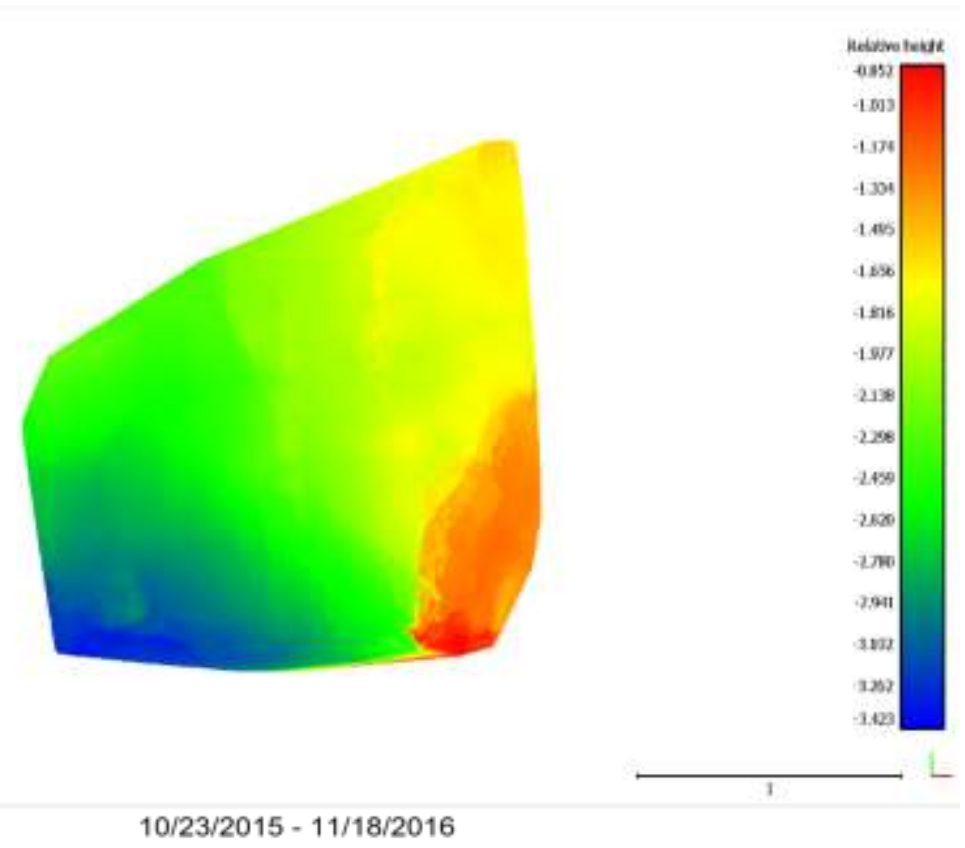

Figure B.5: (A) Shows the pattern and distribution of minimum point to point distances between the knickpoint face on 10/23/2015 and 11/18/2016. (B) Shows a choropleth map of the change in horizontal distance of the knickpoint face between 10/23/2015 and 11/18/2016. All scales are in meters. 
The visual pattern of erosion based on point to point distance between 8/19/2015 and 11/18/2016 is shown in Figure B.6A. This is the longest time span of the interval pairs, during which all three types of erosion occurred. The distribution of measured changes in distance between the knickpoint faces is centered on $1.95 \mathrm{~m}$, which exceeds the MDD of $0.06 \mathrm{~m}$. These points are green and include the majority of points in Figure B.6a. The top right portion of Figure B.6B, red to orange, shows the smallest measured relative upstream retreat of -1.57 to $-1.84 \mathrm{~m}$. Moving right to left toward the base, the integrally measured volume change increases, and the maximum is due to undercutting, shown in blue, that resulted in a maximum of $-3.01 \mathrm{~m}$ of erosion. Total volume of erosion was $-6.49 \mathrm{~m}^{3}$ across the $2.79 \mathrm{~m}^{2}$ surface area of the face (Table 3.1). The amount of upstream retreat for this period was - $2.33 \mathrm{~m}$. 

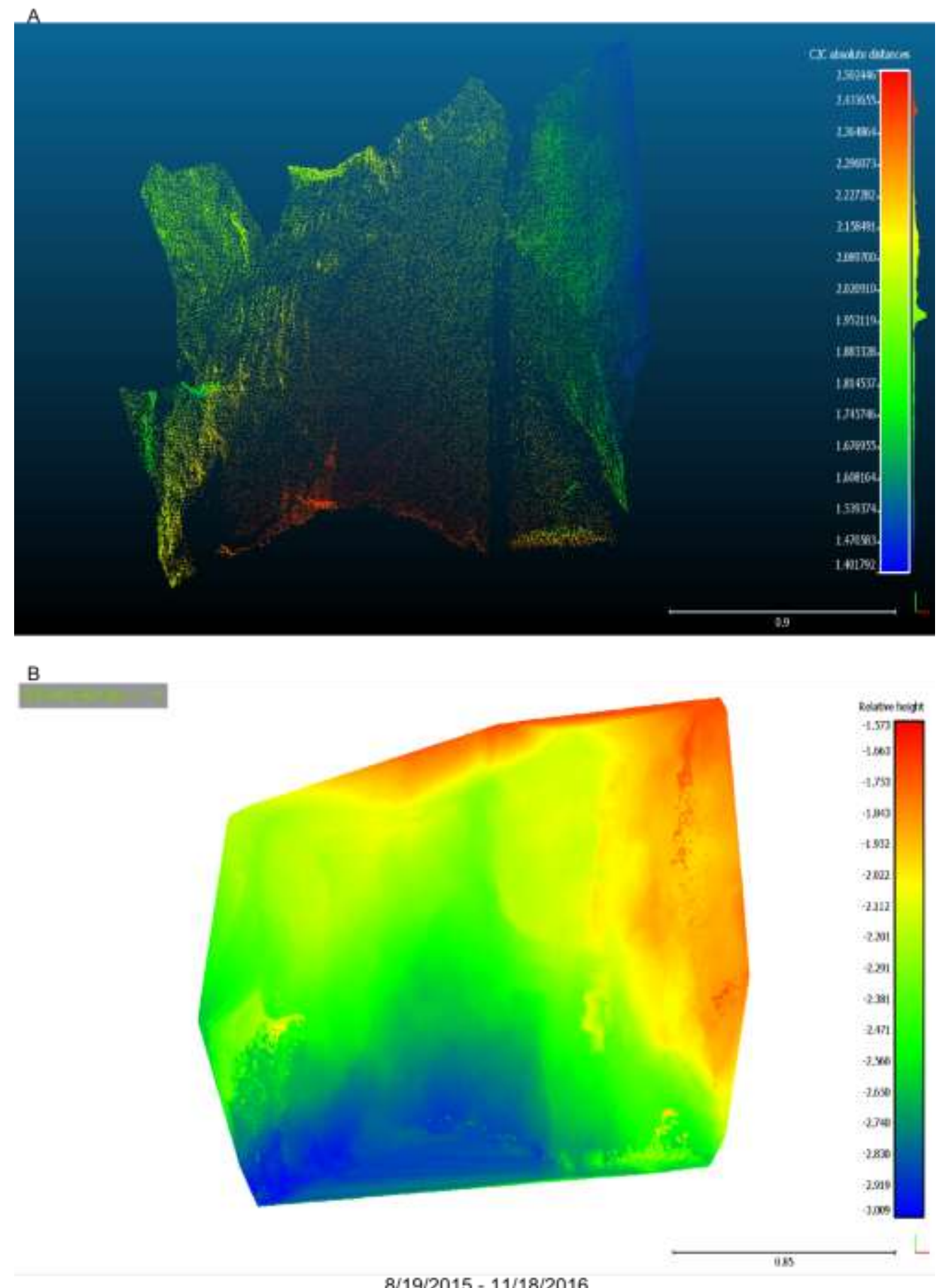

Figure B.6: (A) Shows the pattern and distribution of minimum point to point distances between the knickpoint face on 8/19/2015 and 11/18/2016. (B) Shows a choropleth map of the change in horizontal distance of the knickpoint face between $8 / 19 / 2015$ and 11/18/2016. All scales are in meters 